\title{
Making Way for the Car: Minimum Parking Requirements and Porirua City Centre
}

\author{
Angus Hulme-Moir
}

Thesis

Environmental Studies 593

2010

A 90 point thesis submitted to Victoria University of Wellington, as partial fulfilment of requirements for the degree of Master of Environmental Studies

School of Geography, Environment and Earth Sciences

Victoria University of Wellington

February, 2010 


\title{
Making Way for the Car: Minimum Parking Requirements and Porirua City Centre
}

\author{
Angus Hulme-Moir
}

\begin{abstract}
Minimum parking requirements (MPRs) mandate that each new development provides enough parking to ensure ample provision at the time of peak demand. This approach tends to oversupply parking above the optimal level, and by bundling parking into the development costs, ensures that parking is free to the user. As a result, land-use and transport decisions are distorted. A case study of Porirua central business district (CBD) was undertaken to investigate the use of MPRs in the New Zealand context, and to assess their impacts on transport and land-use patterns. Findings indicate that MPRs tend to oversupply parking relative to weekly mean and peak occupancies. Land use mapping found that 24 percent of CBD land is allocated to car parking and MPRs were shown to contribute to dispersed development patterns. Stated choice data and a cost recovery model for car parking highlight how free and ample car parking provision favours car driving and has distortionary impacts on travel decisions.
\end{abstract}

Key words: environmental policy, transport, minimum parking requirements, parking, integrated transport and land use planning, travel demand management 


\section{Acknowledgements}

There have been a large number of people who have assisted me in the course of this research. At Victoria University, my supervisor Ralph Chapman encouraged me and gave me sound guidance about the study's direction and content. Andrew Rae taught me to use Geographical Information Systems (GIS) from scratch while Dennis Dawson taught me how to use the SPSS statistical program. Thanks go to my classmates for coffees, turning up to count car parks and proof reading my scripts. The stated choice survey would not have gone ahead if it were not for the help of Doug Clover who was more enthusiastic than myself and kindly gave of his time, expertise and resources.

A number of people at Porirua City Council were supportive of the work and gave of their time to help with the study. Winya Su from the GIS department provided the car parking template for mapping land use patterns. Andrew Jones tracked down resource consents and Geoff Marshall provided information on council parking studies.

Wider organisations and individuals whom I wish to thank include the Centre for Sustainable Cities who employed me over the summer of 2009 and gave me a grant toward my research expenses. Quotable Value kindly supplied site and building floor areas free of charge and Lynley Povey at the Ministry of Transport accessed information on travel distances and trip types. Todd Litman (Canada), who has studied this area for many years, kindly read a draft copy and offered comments and encouragement in the process.

Minimum parking requirements are a far cry from what I had initially planned to study. Julie Genter and Stuart Donovan are New Zealand's MPR crusaders and they got me enthused about the idea along with providing advice, ideas and encouragement.

Lastly, I have Mary to thank along with my children Georgia, Jacob and Reuben. They tolerated, at times, an absent and distracted father and partner. They also enjoyed telling all and sundry that their dad counted car parks for a living. 


\section{Contents}

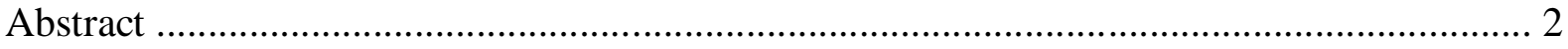

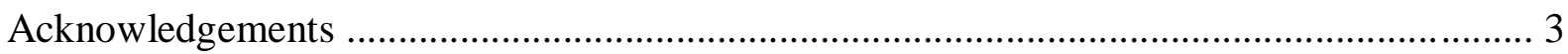

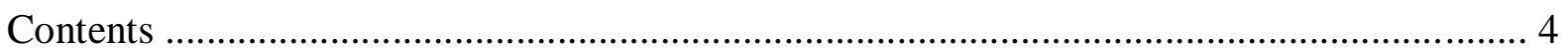

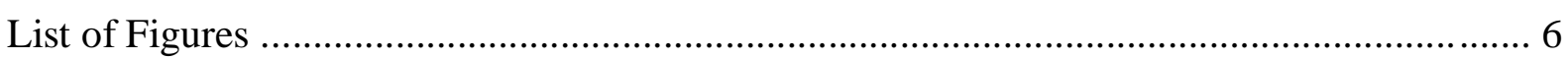

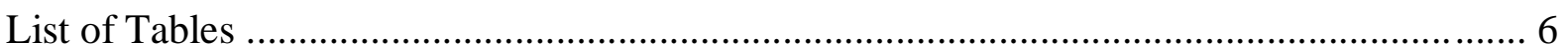

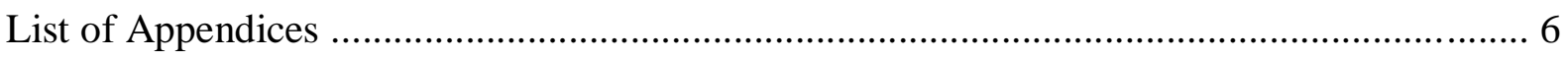

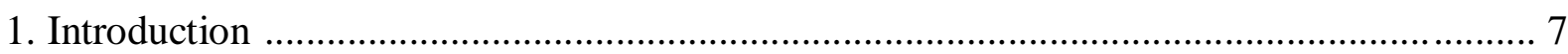

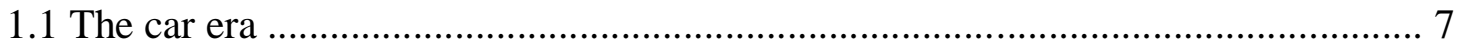

1.2 Environmental and social impacts of vehicle use ............................................. 7

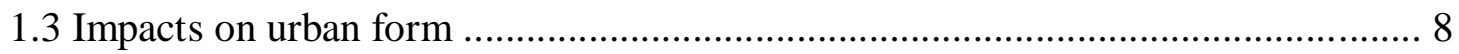

1.4 A transition toward sustainable transport patterns .......................................... 9

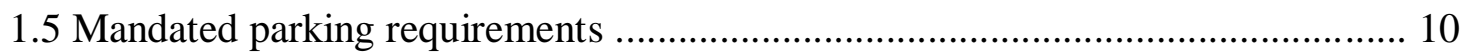

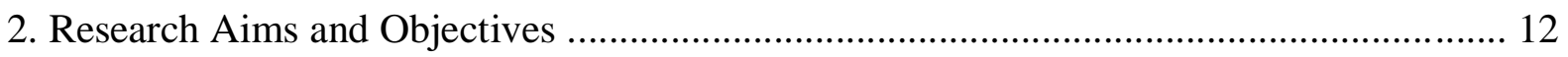

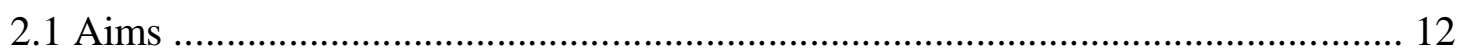

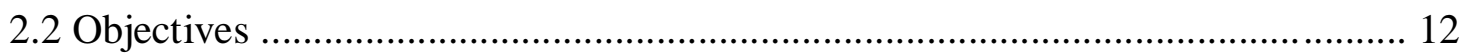

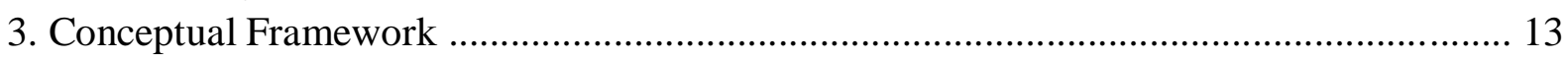

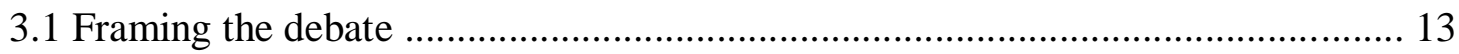

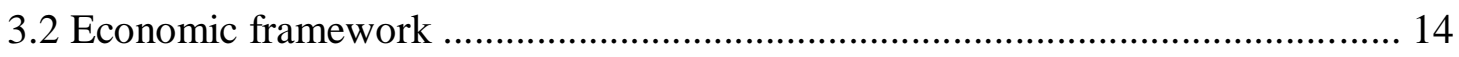

3.3 Market failure in the transport sector ............................................................. 17

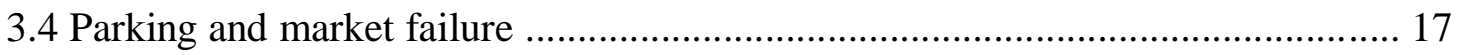

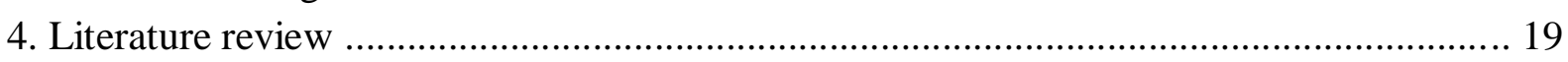

4.1 A brief history of minimum parking requirements ........................................... 19

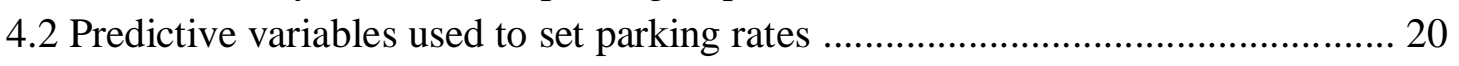

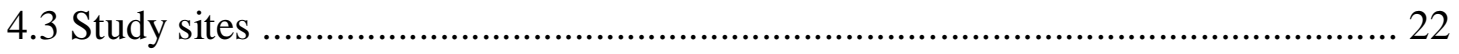

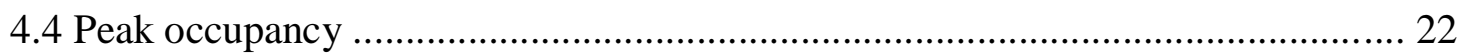

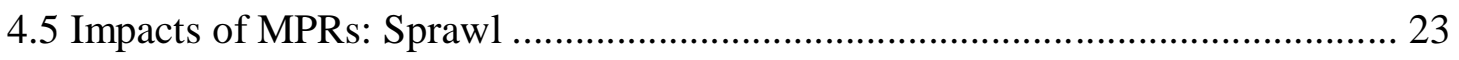

4.6 Impacts of MPRs: Induced demand for driving …........................................ 25

4.7 Impacts of MPRs: Amenity, externalities and other modes ............................... 25

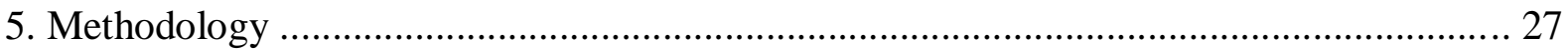

5.1 Research location: Porirua CBD _.................................................................... 27

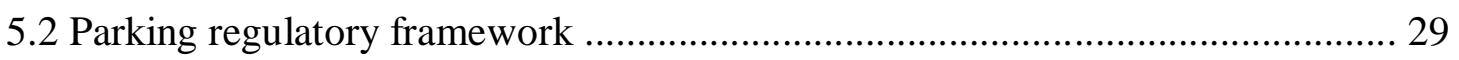

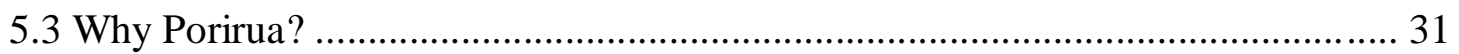

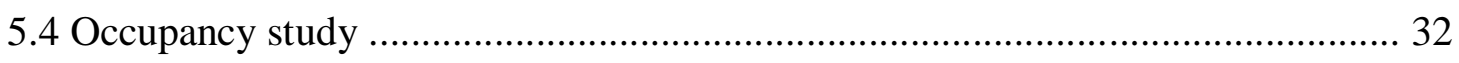

5.5 Geographical Information Systems: Mapping the CBD .................................... 34

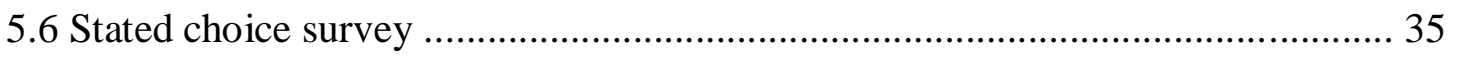

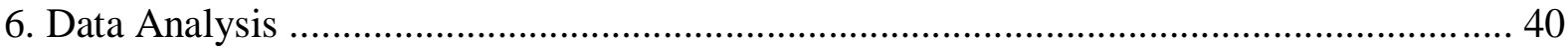

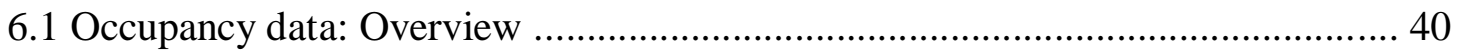

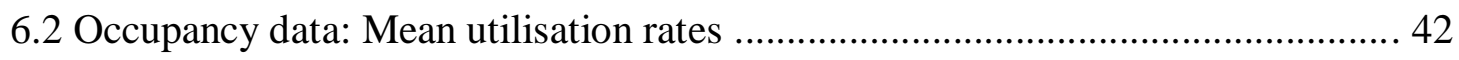

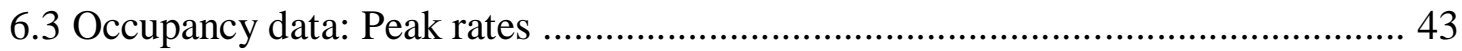

6.4 Correlation between parking demand and GFA ............................................ 47

6.5 Occupancy data: Parking at the walkable scale ............................................... 49

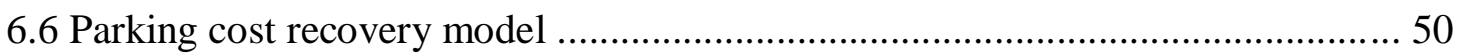




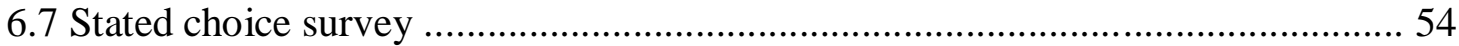

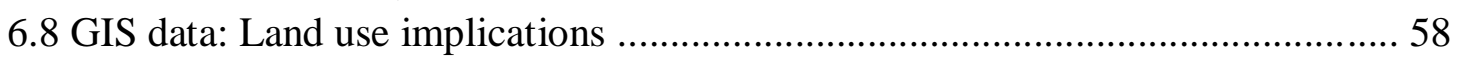

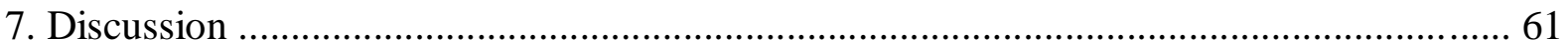

7.1 Five reasons for changing parking arrangements in Porirua .............................. 62

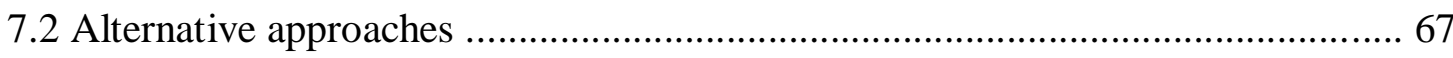

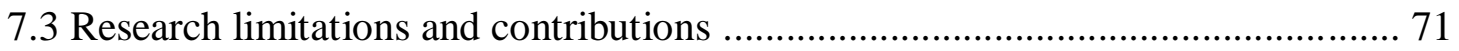

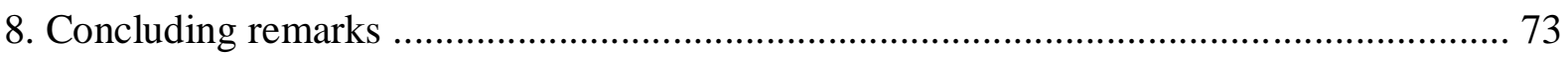

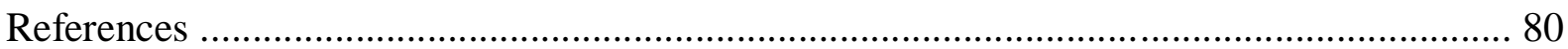




\section{List of Figures}

Figure 1

Hypothetical market for parking

Figure 2

Market for parking under MPRs

Figure 3

Contribution of MPRs to urban sprawl

23

Figure 4

Porirua CBD and environs

Figure 5

CBD zone, sub-areas and portion excluded from the occupancy study

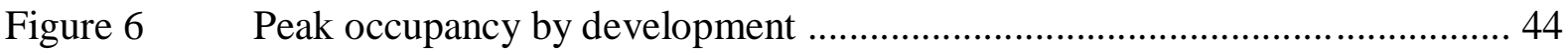

Figure $7 \quad$ Peak parking occupancy relative to standards ............................................. 46

Figure 8 The relationship between GFA and parking occupancy .............................. 48

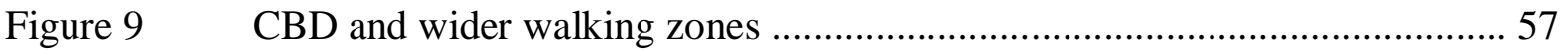

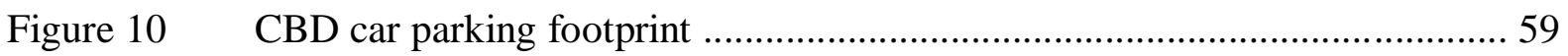

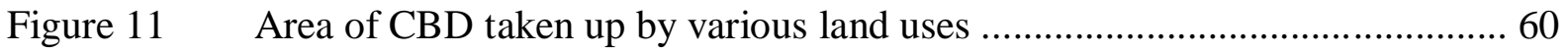

\section{List of Tables}

Table 1 Minimum parking requirements in the Porirua CBD zone

Table 2 Mean car park availability and occupancy and by category and day ............ 42

Table 3 Wider parking supply for a range of developments .................................... 50

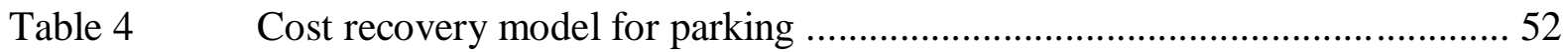

Table $5 \quad$ Cost recovery price of parking as percentage of trip cost ............................. 53

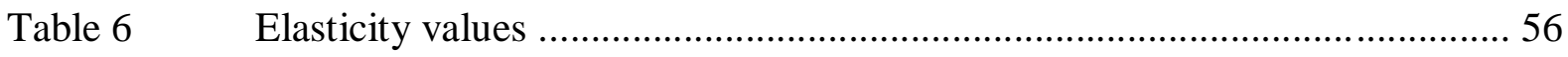

Table $7 \quad$ Commuter response to parking price and walk time ................................... 56

\section{List of Appendices}

Appendix 1- Stated choice questionnaire ......................................................................... 74

Appendix 2 - Variable coefficients estimated using stated choice data ................................ 79 


\section{Introduction}

\subsection{The car era}

The advent of cheap and abundant energy fuelled the massive economic expansion of the last century and brought us the now ubiquitous private motor vehicle. It is 100 years since Model Ts started to roll off the Ford assembly line in their thousands. There are now more than 735 million cars worldwide and most countries are experiencing an upward trend in ownership rates (Poudenx, 2008; Shoup, 2005). Private vehicle travel globally has more than doubled in the three decades from 1970-2000 (Ryan \& Turton, 2007). New Zealand has noted similar trends and its vehicle ownership rates are amongst the highest in the world (Ministry of Transport, 2006).

The private vehicle has offered levels of personal mobility that are nothing short of astounding. It has opened up trade, travel and living locations that were unheard of in previous generations. The worldwide kilometres clocked up in the last 100 years, however, have been far from benign. This unmatched mobility has, amongst other things, contributed to the ever looming climate crisis, had negative impacts on public health and altered the way that cities are built and organised.

\subsection{Environmental and social impacts of vehicle use}

Transport is responsible for around $20 \%$ of the global $\mathrm{CO}_{2}$ emissions and is the fastest growing emissions sector in the Organisation for Economic Cooperation and Development (Gorham, 2002). Private vehicles are the largest contributor to this profile. Climate change, arising from human induced levels of $\mathrm{CO}_{2}$ and associated greenhouse gases, is set to have profoundly damaging, costly and inequitable impacts on the world's population and ecosystems (Barrett, 2006; Hansen, 2008; IPCC, 2007; Stern, 2006). While there is not agreement on what constitutes 'dangerous interference with the climate system', as outlined in the United Nations Framework on Climate Change (2002, p. 10), a political consensus is growing around an upper limit of two degrees average global temperature rise above preindustrial levels (see for example G8 Summit, 2009).

To keep within this target industrialised countries have to undergo a rapid phase of decarbonising with a commonly cited figure of $80 \%$ reductions in carbon emissions by 2050 (IPCC, 2007; Krewitt, et al., 2007). Rapidly developing economies such as China and India will need to be a part of this process as well. This is no easy task. New Zealand as signatory to 
the Kyoto Protocol Agreement signed up to an emissions cap of zero growth against 1990 levels with ongoing responsibility for emissions over and above this level. Over the first commitment period (2008 -2012) emissions have grown, and in 2008 they were $24 \%$ higher than 1990 levels.

While climate change impacts are often intangible, the effect that car use has on public health is immediate. Traffic deaths are estimated at 1.2 million people worldwide with a further fifty million people suffering injuries (Worley, 2006). They are now the leading cause of injuryrelated death worldwide. Although the traffic death rate is declining in many industrialised countries there are also significant health problems associated with vehicle emissions (nitrogen oxides, carbon monoxide, volatile organic compounds and particulate matter) and declining levels of physical activity partly attributable to vehicle use. Across New Zealand every age group is walking and cycling less with trends most pronounced amongst children (Ministry of Transport, 2009). The substitution of the car for active transport modes has implications for the increasing levels of obesity in New Zealand (Woodward \& Lindsay, 2010).

Cities which are home to most of the world's population, and responsible for $80 \%$ of global green house gas emissions, are where these impacts largely arise (Beatley, Boyer, \& Newman, 2009). And much of the car usage leading to these impacts is attributable to the way that urban form has been reconfigured around the private vehicle (Banister, 2000).

\subsection{Impacts on urban form}

"The automobile made the suburbs possible and suburbs made the automobile essential" (Porter, 1999, p. 2). Cities built after the advent of the car are characterised by low density sprawl and extensive road networks. The trend of 'moving away' from the city centre is not just attributable to the car, however. A complex range of social and economic factors have assisted it (Vuchic, 2000). The result is higher levels of car dependence and vehicle kilometres travelled (VKT) relative to more compact forms of living (Ewing, Bartholomew, Winkelman, Walters, \& Chen, 2007; Kenworthy, 2003). Auckland, New Zealand's largest city, is a case in point. It has one of the lowest population densities in the world and public transport use, which in the 1950's was as high as $50 \%$ for journey to work trips, has declined to low levels (Harris, 2007). 
Sprawled development, while reducing transport options, also increases the percentage of the household budget spent on moving around (Litman, 2009a) and generates high levels of road congestion. The economic impacts of this, in the U.S., run in the tens of billions of dollars (Poudenx, 2008) while in the European Union it is said to equate to 1 to $3 \%$ of gross domestic product (Banister, 2000). Banister goes on to point out that this pattern of transport is neither desirable nor sustainable and therefore it is critical to find ways to reduce car travel. A further driver for more sustainable transport patterns is the need to keep urban environments resilient in the face of energy supply shocks and oil depletion.

There is a growing awareness, even amongst conservative commentators, of the rapid depletion of conventional oil reserves (Industry Taskforce on Peak Oil and Energy Security, 2010). Modelling future trends in conventional oil supplies is subject to uncertainty, information gaps and wide ranging projections. Recent work, however, is supporting those who have argued for an imminent peak oil ${ }^{1}$ scenario. The U.K. Energy Research Council reviewed 500 studies on conventional oil reserves and projections. In their findings they recognised a wide range of outlooks but argued that a near-term peak in oil supply (20092031) was broadly accepted (Sorrell, Speirs, Bentley, Brandt, \& Miller, 2009). Further, they suggested that the risks imposed by this were significant and underplayed. Peak oil will be followed by a decline in oil production. The world currently uses around 86 million barrels of oil a day and world demand is projected to rise substantially through to 2030. Supply constraints, therefore, are imminent. The lead-in time for oil substitutes, such as biofuels and electric cars, is measured in decades not years, which is why Hirsch (2005) argues that we are headed for a 'liquid energy crisis'.

\subsection{A transition toward sustainable transport patterns}

Many factors will assist cities to transition toward more sustainable transport patterns, including the uptake of low or no-emission vehicles. Simply exchanging the current stock of vehicles for electric versions, however, does not address congestion, resource depletion, such as lithium stocks for batteries, and shorter term emission reductions. Reducing vehicle travel will have to play a role and within this approach financial incentives will be important. The choice to drive is influenced by the way that vehicle usage is priced (Button, 2005).

\footnotetext{
1 "The term peak oil refers to the maximum rate of the production of oil in any area under consideration, recognising that it is a finite natural resource, subject to depletion." (Campbell, 2006)
} 
It is widely recognized that vehicles do not currently pay their way (Booz Allen Hamilton, 2005; Delucchi, 1997; Donohue, 2008; Porter, 1999). There are significant costs imposed by the transport sector that are not met by the user ${ }^{2}$. Most of the aforementioned social and environmental costs relating to climate change, public health and congestion are not covered by fuel taxes and other vehicle levies. The cost of parking provision is another aspect of car use that is often not fully borne by the user.

When cars are not moving they are parked, and this is most of the time (Marsden, 2006). And moreover, at least in the U.S., parking is free almost all of the time (Shoup, 2005). There is no equivalent data available in New Zealand but given the similarity of our planning and zoning regulations it would be fair to say that outside the central business district (CBD) of larger cities parking is generally free and moreover, many car parks in the CBD are subsidised by the employer. However, there is no such thing as a free park. Someone is paying for it, and car parks, particularly in cities, are not cheap. In New York car parks have been known to sell for a quarter of a million dollars (Vanderbilt, 2008). In New Zealand building an underground car park can cost up to $\$ 40,000$ per park excluding the land cost. The reasons free parking is pervasive are many, however, mandated parking requirements in zoning regulations are a primary cause (Shoup, 2005).

\subsection{Mandated parking requirements}

These are commonly known as minimum parking requirements (MPRs) as they usually prescribe a minimum number of car parks that a given development must supply. The underlying assumption in this approach to parking provision is that buildings, not motorists, generate parking demand (Hess, 2001). As a result the cost of parking is bundled into the cost of development. The wider community, not the vehicle user, then covers the 'hidden cost' of parking when they pay slightly higher prices for goods and services (Shoup, 2005). MPRs became standardised practice in planning regulations, both in the U.S. and much of the world, from the 1950s (Ferguson, 2004).

MPRs, by bundling the cost of parking into developments, not only give rise to free parking but they also tend to supply parking above the optimal level leading to distorted land use and transport decisions (Litman, 2006; Willson, 1995). They encourage urban sprawl by significantly increasing the development footprint (Shoup, 2005); they impact on housing

\footnotetext{
${ }^{2}$ The extent of these unmet costs varies considerably between countries
} 
density by driving up the cost of medium density development relative to low density forms (Litman, 2009b), and they induce vehicle travel by reducing the marginal cost of driving (Booz Allen Hamilton, 2005). When vehicle travel is cheaper than it would be, if all costs were met by the user, there is more driving in the short term and higher vehicle ownership rates in the long term.

Although MPRs are widely used in New Zealand, little research attention has been paid to them. Articles and conference proceedings by transport planners J. Genter and S. Donovan highlight the limitations of MPRs in the light of international research and suggest alternative parking allocation mechanisms (see for example Genter, Schmitt, \& Donovan, 2009). Research reports from the government transport sector have focused on data collection to support a standardised approach to MPRs as they relate to various land uses (see for example Douglass \& McKenzie, 2001; Gabites Porter Consultants, 1996). Little critical attention, however has been paid to both the underlying assumptions in the MPRs approach and what the wider impacts have been on parking allocation, city form and transport patterns. This is not a situation peculiar to New Zealand as parking is a poorly researched component of the transport sector generally (Ison \& Rye, 2006; Marsden, 2006).

The following research aims to advance the study of MPRs. A case study approach is employed in this research to investigate how MPRs, as a parking allocation mechanism, have impacted on parking supply along with the wider implications this has for land use and transport patterns in a small New Zealand city. A body of international research spear headed by Donald Shoup provides the framework for the current project. The use of a stated preference survey as part of this study provides insight into travel behaviour and commuter response to parking prices. The research aims to contribute to a knowledge gap in relation to parking management as a driver of land use patterns and travel behaviour. It has implications for city planning and transport policy, as well as environmental outcomes and policy. 


\section{Research aims and objectives}

The research takes a broad brush approach to the use of MPRs in Porirua City. Both quantitative and qualitative aspects of their use are investigated. I chose a case study approach so that a more detailed analysis of the wider Porirua City context could be undertaken. Reading resource consents and council documents gave insight into the regulatory environment and the response of developers to MPRs. Land mapping provided a visual tool to assess how MPRs have impacted on land use patterns in time and space while also providing critical data for estimating a cost recovery model for car parking in the CBD. Although the stated choice survey of commuters was not directly related to MPRs, it shed light on how free parking strongly influences transport decisions. Moreover, it provides valuable empirical data on travel responses to parking price, should the Porirua City Council look at charging for their long-stay stock.

\subsection{Aims}

To investigate the application of MPRs in Porirua CBD and its implications on the efficiency of parking usage, land use patterns and transport decisions. Furthermore, to assess the responsiveness of Porirua commuters to introducing a price on parking.

\subsection{Objectives}

1. Assess how efficiently the car parking resource is being used in the Porirua CBD with a particular focus on parking use at development sites that have provided parking to meet minimum parking requirements

2. Quantify the land area taken up in surface parking in the CBD

3. Approximate the subsidy to vehicle users from having car parking provided free of charge in the CBD

4. Investigate the behavioural responses of commuters to a range of parking prices

5. Estimate the responsiveness of commuter parking demand with respect to price and walking distance from the CBD 


\section{Conceptual Framework}

This section outlines the conceptual framework that informs the research methodology.

\subsection{Framing the debate}

Accessibility and mobility are essential to a city's economic and social wellbeing. In New Zealand the great majority of trips are undertaken with a private vehicle so parking, and transport infrastructure generally, play a critical role in the efficient movement of goods, services and people. In this sense roads and car parks are essential. The question being explored in this research is what level of provision is appropriate? And the answer to this question is strongly influenced by the manner in which accessibility and mobility are framed.

As pointed out earlier, current transport patterns are leaving an extensive tyre-print on society, urban form and the environment. These patterns can, to a large degree, be attributed to a transport paradigm that has focused on making car use easy (Banister, 2000; Vuchic, 2000). Transport planning over the last 50 years has been characterised by an approach commonly termed 'Predict and Provide' (Hull, 2008; Litman, 2009c). At a simple level this involves observing transport trends (such as vehicle ownership rates and network usage data), using them to predict future transport network needs (such as road capacity), and then providing accordingly.

The historic paradigm effectively frames the problem as not enough road space and car parks instead of too many cars. Button (2006) notes that this has come about as transport provision has used 'time' as its primary currency instead of money. He cites congestion management as an example of this approach. By focusing on travel time reduction road authorities have steadily increased road capacity to increase flow rates. However, it is only in cities that use money (a congestion tax) to tackle congestion that the problem has been alleviated. A further problem with this approach is that it leads to inefficient resource use and comes with a high financial cost (Vuchic, 2000).

Parking management, a subset of transport provision, has followed a similar trajectory with car accessibility, managing flow and safety, and preventing spill-over ${ }^{3}$ as the top priorities (Booz Allen Hamilton, 2006). Minimum parking requirements ensure excellent accessibility

\footnotetext{
${ }^{3}$ When the car parking provided at a site is insufficient for the traffic drawn there, parking can 'spill over' into nearby areas where it is generally not wanted.
} 
for the car at each and every site by mandating developments to provide parking to a level that will easily meet the projected peak demand (Shoup, 2005). And by bundling the parking into development costs MPRs ensure that parking is free.

Car accessibility, however, is only part of the justification for the historic approach. Economic development and business vitality in city centres, it is argued, is an equally important driver. There is no doubt that in the minds of business and community interests there is a strong link between parking and business vitality (Rye, Hunton, Ison, \& Kocak, 2009; Still \& Simmonds, 2000). The empirical evidence, however, is weak.

Still and Simmond's (2000) review of empirical and modelling studies on parking restraint and urban vitality noted a paucity of research and scant evidence of a negative relationship. More recent studies in the area lead Marsden to conclude that, "There is no systematic evidence to suggest that either lax parking standards encourage or that strict standards discourage economic growth" (2006, p. 453). Closer to home, Booz Allen Hamilton's (2006) assessment of parking restraint on business vitality in and around Auckland City came to similar conclusions. There is a concern that charged parking will drive shoppers away from the city centre to suburban sites where parking is free. Hensher and King (2001) investigated this potential dynamic using a stated preference survey of trip makers to Sydney CBD. They found that a range of parking prices had little impact on the decision of whether to forgo the trip.

Even in light of the role parking plays in accessibility and business vitality, the historic paradigm has favoured vehicle use and has led to a level of driving well above what is socially optimal (Litman, 2009c). The removal of the price signal that would otherwise alert road and car park users to the full consequences of their actions has played an important role in this. Driving and parking are cheaper than they otherwise would be and this has distorted transport choices.

Economics provides a framework for understanding how these distortions arise while also providing an insight into how car parking might be allocated more efficiently.

\subsection{Economic framework}

One of economics' major concerns is the allocation of scarce resources between competing interests. Given that peoples' wants are limitless but that resources are scarce, the benefits of 
using a resource need to match the cost of providing it (Callan \& Thomas, 2007). This process can be modelled through the interaction of consumers and producers in a competitive market. Figure 1 shows a hypothetical market for parking. The behaviour of consumers is modelled with the demand curve, and that of producers with the supply curve. The demand curve represents what consumers are willing and able to pay for the benefit of parking their cars. The curve tracks downward as consumption of parking increases with lower prices. The supply curve represents what a parking business is willing and able to supply for a given range of prices. Naturally the curve tracks in the other direction. The two curves intersect at the market equilibrium which is where the parking resource is allocated efficiently. At this point the marginal benefits of consuming the resource are equal to the marginal costs of supplying it.

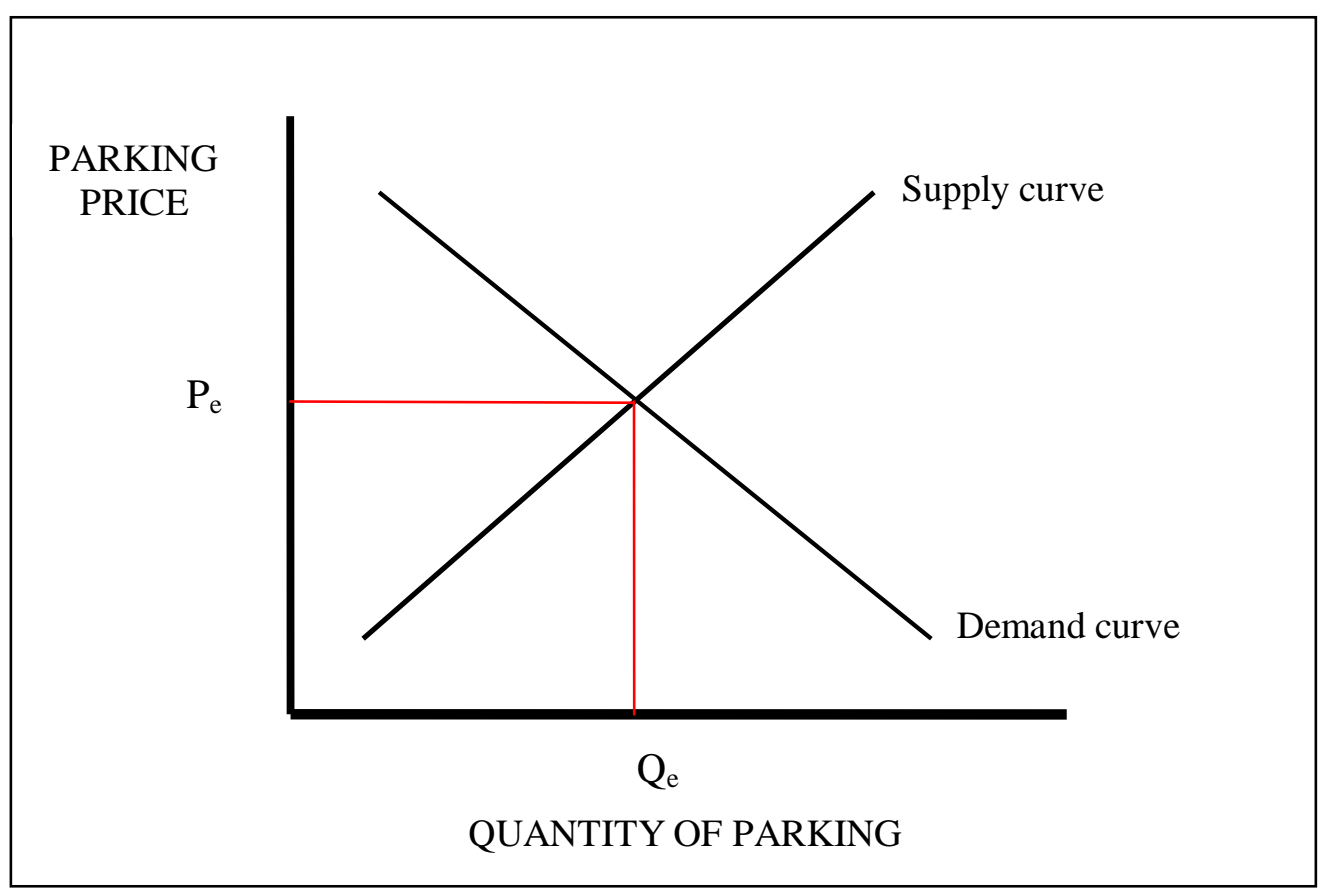

Fig. 1: Hypothetical market for parking

Source: adapted from (Callan \& Thomas, 2007)

The market model highlights two points that are critical to framing an analysis of MPRs.

Firstly, in a market for parking, the benefit a consumer derives is what they are willing and able to pay for it (all else held constant ${ }^{4}$ ). Hence, the quantity demanded is a function of price. Secondly, failure to pass onto the consumer the costs of providing the car parks will lead to a misallocation of the parking resource. MPRs bypass the market system by fixing the rate of

\footnotetext{
${ }^{4}$ All the other factors that influence an individual's preference are held constant in the model. These might include how much time the person has and their perception of public transport.
} 
supply irrespective of costs and benefits and thereby driving the consumer price to zero. This can be shown graphically by replacing the supply curve in Figure 1 with a supply curve generated under MPRs conditions.

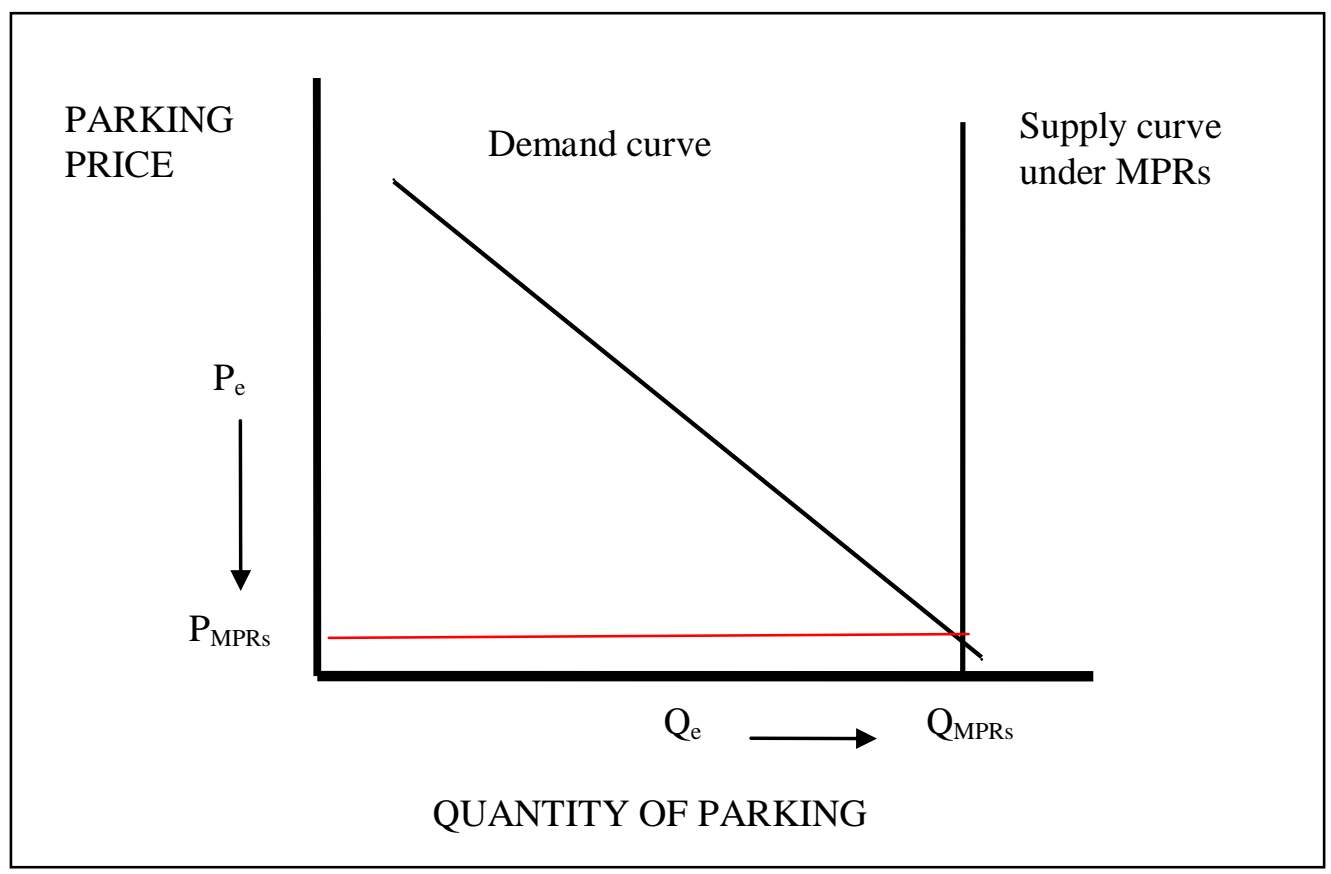

Fig. 2: Market for parking under MPRs

Source: adapted from (Shoup, 2005)

In Figure 2 the supply curve is fixed. A large amount of parking is supplied at all prices. This drives up the demanded parking quantity from the efficient level $\mathrm{Q}_{\mathrm{e}}$ to $\mathrm{Q}_{\mathrm{MPRs}}$. Likewise, the consumer price is driven down from $\mathrm{P}_{\mathrm{e}}$ to $\mathrm{P}_{\mathrm{MPRs}}$, which is at or close to zero.

When a resource is not allocated efficiently the market is said to fail. This occurs whenever competitive conditions are not met. Competitive markets require:

- Many producers and consumers

- Private goods, i.e. goods that are both rival and excludable ${ }^{5}$

- All relevant information is available to all stakeholders

- Costless entry and exit for firms

- The absence of external costs (externalities). These are costs that are not borne by the consumer when the good is exchanged or consumed. Instead they are borne by the wider community and environment. For instance, pollution from car exhaust imposes

\footnotetext{
${ }^{5}$ Excludable means that the goods can feasibly be charged for. Rival means that one person's use of the good precludes others.
} 
a cost on society and the environment that vehicle users don't pay for in their role as drivers

All the conditions of a competitive market are seldom if ever met, yet despite this, many areas of the economy operate competitively. The transport sector, however, is a notable exception (Button, 2005).

\subsection{Market failure in the transport sector}

As the Nobel prize-winner Vickrey noted fifty years ago, "....in no other major area are pricing practices so irrational, so out of date, and so conducive to waste as in urban transportation" (1963, p. 452). There are many reasons for market failure in the transport sector including the potential for monopolistic behaviour, public goods features and the play of wider social and economic goals (Button, 2005; Glaister \& Mallard, 2008). Roads have public good characteristics in that they are seldom rival (except in the case of congestion) and there is no general economically practical way to charge drivers for their use (Button, 2005). Private provision would be sub-optimal as social benefits outweigh private costs in many instances. For these reasons transport networks have by and large been provided by the public sector around the world.

The other reason for market failure in the transport sector is that the full costs of vehicle use have not been internalised. Putting a monetary value on external costs is controversial. For example, what is a life worth in dollar figures? Where attempts have been made to quantify these costs they are substantial (Crouse, 2000; Donohue, 2008; Porter, 1999; Shoup, 2005). A study by Jakob, Craig, \& Fisher (2006) sought to quantify the external costs of accidents, pollution and climate change imposed by Auckland drivers in 2001. Their calculations suggest that the cost of petrol, at that time, would have needed to rise by 68 cents per litre to ensure that users were paying their way. It is beyond the scope of this study to list and evaluate all the external costs imposed by vehicle use. Suffice to say, that transport provision has facilitated easy access for vehicle users with little regard for the wider cost. In this respect parking provision has been similar.

\subsection{Parking and market failure}

Unlike roads, parking cannot claim the protection of the public goods umbrella, nor for that matter the high upfront costs. The parking meter was developed in 1935, so parking has long been excludable as well as rival. There are various reasons, however, preventing an optimal 
allocation of the resource. Factors such as information barriers, the effects of traffic congestion by vehicles looking for a car park and environmental externalities mean that parking markets tend to be, in economic terms, 'second best' (Anderson \& de Palma, 2004; Button, 2006; Feitelson \& Rotem, 2004). Nonetheless, a competitive market for parking does exist in many places and even kerb parking, a good supplied by local authorities with arguably some public good features, can be priced at market rates. Equity concerns, which are a major issue in private roading provision, can be managed through requirements for allocated disability parking and alternative transport options (Shoup, 2005).

Although parking is a marketable commodity, MPRs bundle it into developments thereby bypassing the market system. Even in the absence of MPRs (such as in Wellington City) developers sometimes supply free parking. This partly reflects the historic development pathway that has been created by previous parking regulations. To remain competitive, developments need to provide what rivals provide. Under either scenario, an inefficient allocation of the parking resource occurs with prices driven to zero. This distorts transport decisions and the extent of this is highlighted by the fact that market-priced parking is the largest variable cost component of a single or average occupancy vehicle commute trip into Auckland or Wellington CBDs (Booz Allen Hamilton, 2005). MPRs are also regressive as all development users (including those who don not own a car and/or come by other means) are covering the cost of parking in the prices of goods and services. Lastly, when a minimum amount of parking is mandated the developer is unable to supply parking appropriate to the marginal benefit that will accrue from each extra parking space.

For the reasons outlined above this study employs an economic framework for assessing the efficiency of parking allocation under the MPRs model. The next section looks more specifically at the history of MPRs and the methodology used to determine parking rates. This is followed by a discussion of the wider impacts that MPRs have on land use and transport patterns. 


\section{Literature Review}

"The right to have access to every building in the city by private motorcar, in an age when everyone possesses such a vehicle, is actually the right to destroy the city" (Mumford, 1964, p. 23).

\subsection{A brief history of minimum parking requirements}

When the age of the private vehicle began in the U.S. at the turn of the $20^{\text {th }}$ century a parking problem arose. By 1918 Ford was producing half a million Model Ts a year (Porter, 1999). Cities had not been designed to accommodate the car and serious congestion resulted. The streets of Chicago in the 1920s were more congested than they are today (McDonald, 2007). The parking meter would not become available until 1935 and street space was limited. To accommodate these vehicles car parks sprang up on private and disused land. Even city parks were utilised. In the ensuing chaos efforts to manage parking began.

Work to integrate parking into city planning began as early as 1909 in the U.S. (McDonald, 2007). In 1923, Columbus Ohio, enacted parking requirements as part of its zoning laws. While zoning for parking was initially slow to take on, parking requirements became ubiquitous within a short space of time (Ferguson, 2004). By the late 1960s most U.S. cities exceeding 25,000 people had parking regulations in place. Land uses covered by parking requirements also increased from ten, to the present day level of more than 100 classified types.

Minimum parking requirements are the most widely prescribed parking regulatory tool in use in the U.S., Australia and New Zealand (Ferguson, 2004; Seibert, 2008; Traffic Design Group, 2005). Ferguson notes, that their “... popularity as a planning tool remains virtually unchallenged in professional practice today, despite more than two decades of fierce opposition from increasingly vocal critics" (2004, p. 178). Notable exceptions in the New Zealand context are Wellington City (with no minimum requirements) and Auckland City which imposes maximum parking requirements in the CBD. 
MPRs are informed by a methodology which has been fiercely criticised, most notably by Donald Shoup (2005). Three methodological assumptions, in particular, lead to an oversupply of parking under minimum parking requirements. They are:

- The predictive variables used to set parking rates

- The choice of survey sites

- The use of peak parking occupancy as the supply benchmark

\subsection{Predictive variables used to set parking rates}

MPRs implicitly assume that the parking needs at a given site can be predicted from some characteristic of the land use. Establishing these characteristics and rates has been the task of planning and traffic engineering organisations such as the U.S. Institute of Traffic Engineers (ITE). New Zealand has relied heavily on American (ITE) and Australian Road Transport Authority (RTA) data, as the first major review of local survey data since the late 1960s was not released till 2001 (Douglass \& McKenzie, 2001). This latter project collated the results of trip generation and parking surveys that had been carried out by local authorities and private consultancies across New Zealand. As a result of this initiative, a New Zealand Trips and Parking Database Bureau was established as a collective resource for local authorities and interested parties (2008). The bureau provides survey data from the mid 1990s through to the present day. According to Michelle Lewis from the New Zealand Transport Agency it remains relatively patchy as sourcing information has been problematic (personnel communication, November, 20, 2009).

The predictive variables used to set parking rates have varied and increased over time (Ferguson, 2004). Supply side variables such as rooms, beds and chairs were popular early on and continue to be so in residential and hotel rates. Demand side variables such as number of employees and vehicles have become increasingly popular. In New Zealand, and the U.S., spatial variables such as gross floor area (GFA) or gross leasable area are the most common variable, particularly for retail (Douglass \& McKenzie, 2001; Shoup, 2005). Shoup (2005) found, in a survey of 66 cities that 27 different variables were used for determining parking provision at funeral homes. This calls into question the credibility of this approach.

As the planning practice of MPRs is so widespread, it would suggest that the relationship between the predictive variables and parking occupancy is strong. The degree of correlation between two variables is determined by regression analysis and given a value $\mathrm{R}^{2}$. There is 
general agreement that $\mathrm{R}^{2}$ values are as follows: between 0 and 0.3 the relationship is said to be weak while between 0.7 and 1 the relationship is strong. For a firm relationship to be established a reasonable sample size is also needed. Shoup (2005) highlights weaknesses in both the number of supporting studies for many land uses (in ITE publications), and their $\mathrm{R}^{2}$ values. In the ITE's 1987 Parking Generation handbook almost a quarter of the recommended parking rates are based on one study. Secondly, a number of the $\mathrm{R}^{2}$ values are very low, suggesting a small sample size and/or a weak relationship between occupancy rates and the predictive variable. Fast food outlets, for example, have 18 supporting studies and an $\mathrm{R}^{2}$ value of 0.038 . This means that less than four percent of the occupancy rate can be explained by the relationship to the predictive variable (in this case gross leasable area). Button (2005) also argues strongly against the use of low $\mathrm{R}^{2}$ values in transport planning. Shoup (2005), however, is selective in his analysis. Other land use categories have a larger number of supporting studies and stronger correlations (Ferguson, 2004). Low $\mathrm{R}^{2}$ rates in ITE publications also come with a warning; 'caution, use carefully'.

The industry is at pains to point out that context is critical and that other variables should be used (Ferguson, 2004; Institute of Transportation Engineers, 2004). Douglass and McKenzie's report states, "Many other factors in addition to floor area obviously need to be considered when assessing such developments" (2001, p. 47). However, they fail to specify what the other variables are and then, regardless of the robustness of GFA as a predictive variable, continue to use it to suggest a retail parking supply rate. As Shoup (2005) points out, the data is presented with a level of precision that gives it an air of authority. The fact that MPRs are so widely used in planning regulations suggests that the 'caution, use carefully' warning plays second fiddle to the dominant perception that they are reliable. Blame also lies with local authorities who have been shown to set their parking rates by simply copying the neighbouring districts, and often rounding them up in the process (Willson, 1995).

The predictive ability of the ITE rates shows up poorly in other countries and contexts. Fam and Lam (1997) applied ITE rates in Singapore and found that they created a massive oversupply. Within the CBD peak demand was only 25 to $30 \%$ of the recommended rate. Medium density housing in transit orientated developments also display markedly lower requirements than what is commonly prescribed (Topp, 2009). Douglass and McKenzie (2001) make reference to New Zealand studies carried out in the 1980s on fast food and liquor outlets. An attempt was made to establish 'best predictors' for the number of customers through the 
door. Catchment population and passing traffic, not GFA and employee numbers were the most significant. The factors contributing to parking demand are complex and parking rates needlessly oversimplify this (Hollyoak, 2009; Litman, 2006; Shoup, 2005), resulting in an inflated supply estimate. Another factor contributing to this outcome is the location of study sites.

\subsection{Study sites}

Occupancy data from the U.S. has largely been collected from suburban sites, where all parking is provided onsite, where single land $u^{6} e^{6}$ patterns prevail, little or no public transport is available and parking is free (Shoup, 2005). Hence, ITE references to 'parking demand' are really demand at sites with few transport alternatives and where parking is free. These sites have inflated parking demand relative to other locations such as city centres, which benefit from high density, mixed land use types and alternative transport modes.

New Zealand survey sites are similar, being skewed toward suburban areas (NZ Trips \& Database Bureau Inc, 2009). There is also little data from Wellington, which abolished MPRs in 1991. Arrival by alternative modes has not been accounted for, except in recent years, and this has been limited. The obvious departure from ITE studies is that many of the surveyed sites involved shared parking. Large scale developments involving a range of different shops and businesses sharing a common parking resource became popular through the late 1990s.

\subsection{Peak occupancy}

Lastly, supply rates are inflated by the use of peak demand as the benchmark. Further attention is given to this area in the methodology section. Parking, like other areas of transport, is strongly influenced by time with peak and off-peak demand rates varying according to land use type. Some land uses, like office buildings, have fairly consistent weekly demand patterns. Others, particularly retail, are subject to seasonal demand with large increases in customers leading up to Christmas. To account for this, the traffic engineering sector uses the 'design hour' to guide the assessment of peak period. A design hour is simply the number of hours in the year when the car park will be technically full. And 'technically full' is commonly accepted to be $85 \%$ occupancy (Douglass \& McKenzie, 2001). For New Zealand, Douglass and McKenzie recommend the $30^{\text {th }}$ design hour for retail which falls around the fourth busiest week in early December. What this means is that the car park will

\footnotetext{
${ }^{6}$ Single land use patterns are where zoning arrangements have not allowed for a mix of uses in a given area, such that residential, retail and entertainment developments might all exist in the same zone.
} 
be technically full (with up to $15 \%$ of the spaces available) for only 29 hours of the year. The remaining time, by implication, it will be oversupplied. All the technical jargon hides the obvious point that design hours are constructs unrelated to the marginal cost and benefit of supplying an extra car park (Shoup, 2005), but consistent with the paradigm of facilitating car use. Naturally, this approach commonly results in an oversupply of parking (see for example Albanese \& Matlack, 1999; Willson, 1995). Catering for peak demand ensures that many car parks are underutilised most of the time leading to an inefficient allocation of land and money.

The application of rates based on the aforementioned assumptions has the effect of ignoring the heterogeneity of urban conditions and risks while duplicating high levels of parking with resulting poor land use and transport outcomes.

\subsection{Impacts of MPRs: Sprawl}

The manner in which MPRs contribute to sprawl in city and suburban centres is illustrated in Figure 3.

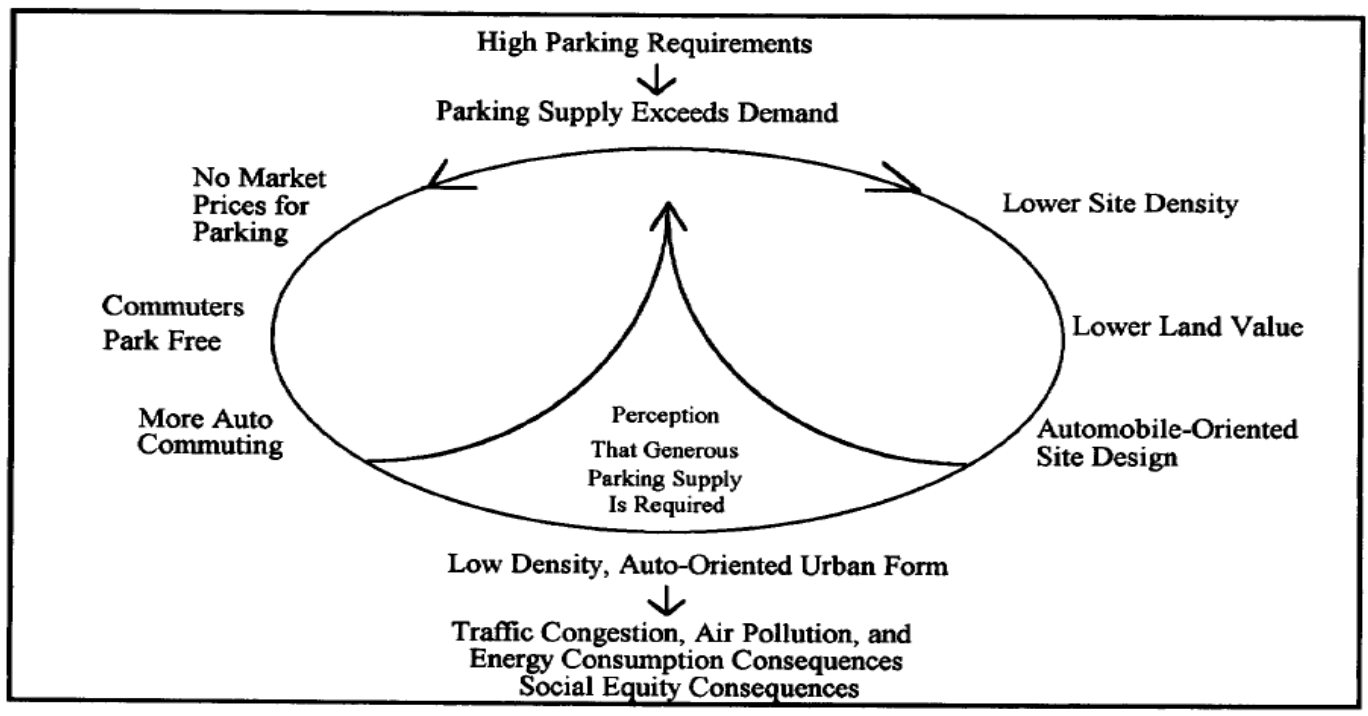

Fig. 3: Contribution of MPRs to urban sprawl Source: (Willson, 1995)

Figure 3 is a simplified analysis focused on parking. A wider, complex set of factors contribute to urban sprawl (Vuchic, 2000). Local and regional planning policies, tax incentives, economic drivers such as rising wealth and land costs, urban crime and changing preferences are some of these. The private vehicle has not been the only cause of sprawl but it has certainly facilitated the desire to 'move out' of the city. Subsidisation of vehicle travel (of 
which free parking is a factor) has meant that the inevitable trade off between travel costs and other considerations looks rosier than it should. The role that various contributing factors play and how they intersect is complicated (Chapman, 2008) and outside the scope of this study. MPRs, however, play a role in urban sprawl by requiring large parking footprints that consume scarce land and drive developments to cheaper locations on the fringe of cities. It is only economic to build structured parking, and thereby reduce the parking footprint, when land values are very high (Litman, 2009b).

The following example illustrates the size of parking footprints under commonly used MPRs:

- MPRs for retail development are 4 to 5 car parks per $100 \mathrm{~m}^{2}$ GFA (Douglass \& McKenzie, 2001)

- Small retail development of $2000 \mathrm{~m}^{2}$ GFA

- 80 -100 parks required. Each park needs around $27 \mathrm{~m}^{2}$ of land for access and circulation (Litman, 2009b)

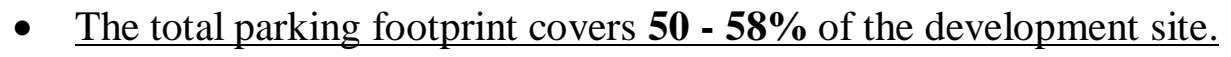

An indirect sprawl effect comes about as developments move out to the city fringe and suburban areas to offset the land cost (Willson, 1995). MPRs for residential categorys drive up the cost of more compact forms and favour low density development in the suburbs over medium density development closer to the city (Litman, 2009b). For 'typical affordable housing developments' meeting the required minimums can increase the cost of development between $12 \%$ (1 car park per unit) and 25\% (2 parks per unit). Lower development densities mean that, at its worst, the city centre becomes a series of buildings dotted in a sea of parking (Shoup, 2005). This pattern of land use aggravates vehicle dependence and leads to excessive driving (Brownstone \& Golob, 2008; Ewing, et al., 2007). In an interesting study on the influence of location on vehicle kilometres travelled (VKT), Beauvais (2008), found that supermarkets on the city fringe generated double the VKT (per $€ 100$ spend) compared to supermarkets in the city centre.

\subsection{Impacts of MPRs: Induced demand for driving}

MPRs oversupply parking, thus driving the consumer price of parking to zero. This induces additional vehicle travel (Booz Allen Hamilton, 2006; Shoup, 2005), although the extent of this behaviour is context specific. There is a lack of research on the relationship between parking price, parking supply restraint and impacts on parking demand and travel behaviour (Hensher \& King, 2001; Marsden, 2006). Available data comes from both empirical and 
modelling studies. The following figures are based on commuter demand for parking which is better understood than other trip purposes.

'Cash out' studies in California found that cashing out (where the value of employer subsidised parking is paid up in cash to the employee) reduced driving to work by $11 \%$ (Shoup, 2005). A review of both empirical and modelling studies from the U.S. found price elasticities ${ }^{7}$ of between -0.1 and -0.6 with an average of -0.3 (TRCP, 2005). This average figure means that if the price of parking increases $10 \%$ demand for parking falls by $3 \%$. Booz Allen Hamilton (2006) suggest a higher figure of -0.9 for seven plus hours of parking. Marsden (2006) notes that elasticity values are often context specific, dependent on variables such as the wider availability of parking and transport alternatives.

What is equally unclear is the degree to which reduced parking demand results in modal change, substitution of the parking resource (long stay for short stay) or simply a spill-over to other areas (Rye, Cowan, \& Ison, 2004). Marsden suggests the latter; "In summary, a shift in parking location appears to be the primary behavioural response of commuters to parking restrictions" (2006, p. 450). However, in the situation where a raft of policy measures is in place including region-wide parking strategies and other travel demand initiatives, shifts in modal behaviour can be significant (Mildner, Strathman, \& Bianco, 2006; TRCP, 2005). The elasticity of parking demand with respect to other trips, such as leisure and shopping, is poorly understood (Hensher \& King, 2001).

MPRs have a number of other negative environment and visual impacts. This is exacerbated by the fact that they can be the primary land use in commercial retail areas (Akbari, Rose, $\&$ Taha, 2003).

\subsection{Impacts of MPRs: Amenity, externalities and other modes}

Parking lots are one of the least attractive elements of city form and can dominate development sites. As MacDonald notes,

"Parking requirements now drive many site designs and are often the make or break issue for financing new developments. Too many quality smart growth

\footnotetext{
${ }^{7}$ Price elasticity is the change in the demand for a good that results from a change in parking price. Generally the relationship is negative, i.e. as price goes up the demand for a good goes down.
} 
projects remain on the drawing board because they simply cannot solve the parking dilemma. We need parking, but we need to re-think parking design, parking financing and parking supply and demand to better meet the needs of communities, developers and users" (2007, p. 233).

Parking surfaces also increase the rate and volume of storm water runoff and shed pollutants such as heavy metals, oils and radiator fluid. This combined effect degrades urban streams and is toxic to aquatic life (Albanese \& Matlack, 1999). These authors note that reducing car park supply to match actual demand would go a long way to mitigating the volume of water runoff.

MPRs result in on-site parking at each and every development. While this provides easy access to vehicles, it is at odds with a walking and cycling friendly environment (Mumford, 1961; Vuchic, 2000; Zacharias, 2001). MPRs disperse developments while increasing traffic circulation and kerb-cuts. The implicit transport hierarchy in this approach is highlighted by Vanderbilt who notes that, "As a testament to the inherent bias of the profession no engineer has ever written a paper about how 'vehicular interference' disrupts the saturation flow rates of pedestrians trying to cross the street" $(2008$, p. 112).

Creating a walkable environment and getting people out of their cars are two separate issues and parking restraint plays a role (Stubbs, 2002). In Chapman's analysis of how mixed land use and density impact on travel behavior he notes, "Policies solely to make things better for walkers may not reduce driving. The analysis presented here suggests that relaxing road and parking standards would reduce auto use and, under the right circumstances, increase walking/biking and transit use" (2008, p. 1026). In the Copenhagen experience the increase in cyclists (now greater than $30 \%$ of the daily commute share) happened in conjunction with the removal of 2,500 parking spaces over ten years (Beatley, et al., 2009).

Parking is a vital component of the transport network. It has a useful role to play in promoting accessibility. That parking is not an end in itself, but simply a means of access, is sometimes forgotten when the value of abundant parking is being promoted. In summary, MPRs as an allocation mechanism cause an oversupply of parking relative to the optimal level resulting in a range of untoward effects on urban form, urban vitality and transport patterns. 


\section{Methodology}

The following section describes the case study area, why it was chosen and the methodology used in the various data collecting projects.

\subsection{Research location: Porirua CBD}

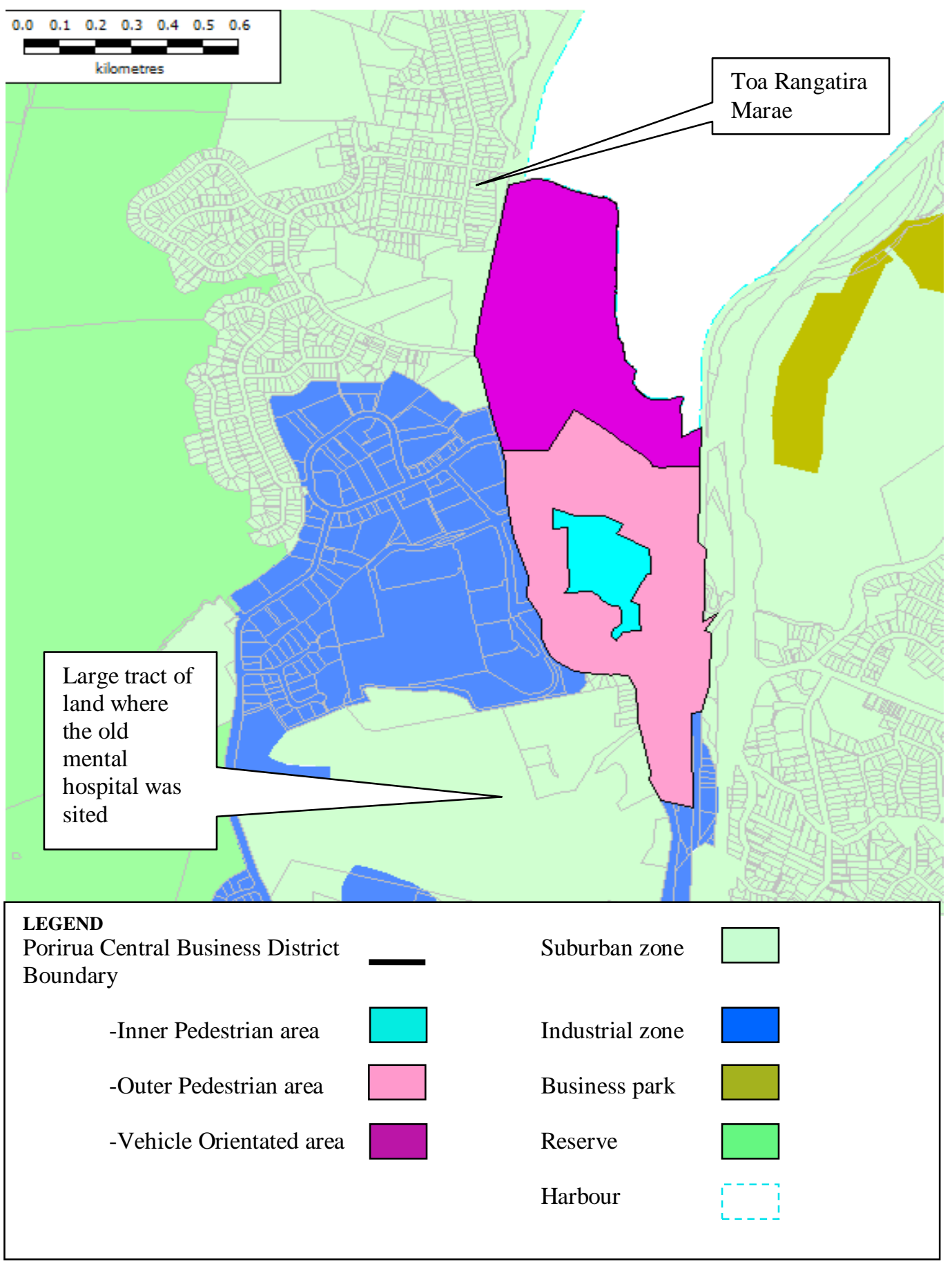

Fig. 4: Porirua CBD and environs

Source: Adapted from GIS maps (http://gis.pcc.govt.nz/pccinvoker/default.aspx) 
Figure 4 outlines the various district plan zones and where they sit relative to the CBD. It provides a visual reference point for the discussion that follows.

Porirua began its transformation from village to city in the late $1950 \mathrm{~s}$ and early $60 \mathrm{~s}$. The area had a long Maori history prior to this. In more recent times Te Rauparaha established Ngati Toa Iwi as the Tangata Whenua ${ }^{8}$ with a series of invasions at the turn of the $19^{\text {th }}$ century. The ancestral home of Ngati Toa, Toa Rangatira Marae, continues to be used and is situated in Takapuwahia. European settlement started in the 1840s and a large mental hospital was built to the south and west of the present city centre in 1887 . Despite this development, Porirua retained its village-like character until the 1950s (Scrimgeour, 1995). At this stage the area was chosen for development as a satellite centre for Wellington. Work began in earnest on a centrally planned design to provide state housing, a regional shopping centre and commercial opportunities (Dudding, 1963).

The city centre was designed around an English town format with clustering of commercial, retail and entertainment areas but separation of pedestrians and traffic (Einhorn, 1969). Following the rapid development of the town centre in the 1960s growth slowed until a renewed burst of development in the early 90s. This began with the opening of a large enclosed shopping mall in 1991. A planning process in 1989, to assess the long term land and transport needs of the city centre, resulted in an expanded CBD zone to include the 'vehicle orientated area'.

The wider city is spread out around two harbour inlets and up along the coast. Much of the suburban development follows the transport spine coming out of Wellington City and heading north. Porirua CBD sits adjacent to State Highway One and the main trunk railway line. There are around 50,000 people living in the city, which makes it relatively small by New Zealand standards. Three thousand-seven hundred businesses, not counting the government sector, provide work for around 15,000 employees (Statistics New Zealand, 2008). The largest employment sectors are retail and education. The city is also well endowed with beaches, harbour and forested areas.

\footnotetext{
${ }^{8}$ Literally 'people of the land'. This imparts 'mana whenua' or customary authority regarding land use and cultural practices in the area
} 
There has been substantial employment growth in most sectors within the last ten years (Property Economics, 2008). This report also suggests that demand for land going forward, particularly on the part of the wholesale and industrial sectors, will be high. A 'business park zone' has been developed to the east and north of the city to cope with some of the anticipated demand for space.

The Porirua CBD covers around $0.7 \mathrm{~km}^{2}$ and is approximately bounded by the harbour, the stream to the east, and the arterial road leading out to the western suburbs. The Porirua District Plan (1999) further divides the CBD zone into three sub-areas for management purposes: The Inner Pedestrian area, Outer Pedestrian area and in the north the Vehicle Orientated area. In the following section direct quotes are drawn from the district plan. These have been written in italics to avoid the need to provide a reference at the end of each quote.

\subsection{Parking regulatory framework}

The Plan's intention is to manage the CBD as an integrated whole and so most activity rules and standards apply across the whole zone. Parking standards are one of the few rules that vary between the three sub-areas. Parking is managed primarily through the district plan standards and objectives. Although attempts were made to establish a regional parking strategy, this did not eventuate.

The National Transport Strategy (2008), while pointing to the role of parking in promoting a more sustainable transport system, does not prescribe a management approach. The Regional Land Transport Strategy (2007) is a little more prescriptive in this regard. Ongoing iterations of this policy document have advocated for restrictions on long-stay parking in urban centres to manage commuter traffic. The Porirua District Plan gives effect to this sentiment in policy objective C1.2.2;

To ensure adequate car parking is provided to meet the needs of visitors and workers in the city where 'adequate' recognises that total parking provision will be consistent with the Wellington Regional Land Transport Strategy. The council adjusts the long-stay parking stock to achieve some level of travel demand management. In other respects, parking in the CBD is managed via a range of district plan objectives that relate both to the wider zone as well as the various sub-areas. For new developments, the district plan requires that all the parking that is likely to be required by 
those buildings over time is provided on site, recognising changing use patterns. To achieve this, minimum parking requirements are in place in all the sub-areas.

MPRs in Porirua are based on the gross floor area (GFA) of the building, not the land use type. One rate applies to all land use categories. This appears to be an atypical approach to MPRs, with most New Zealand cities having a range of standards for different land use types (Traffic Design Group, 2005). The district plan justifies this approach as sustainable management on the basis that it ensures adequate parking and reduces the potential for buildings to lie vacant as a result of not being able to accommodate activities with higher parking demands.

Standards have been set high to ensure there is not a shortfall in the long term. This is an approach based on capacity provision rather than sustainable management (Litman, 2006).

MPRs vary in each sub-area recognising historical configurations and differing policy goals. The Inner and, to a lesser extent, Outer Pedestrian areas were designed around shared parking and a focus on pedestrian movement. In line with this, policy objective C1.1.2 states,

To promote a pedestrian focused environment in the City Centre that provides a high level of visual amenity and pedestrian convenience while minimising the adverse environmental effects of vehicle traffic.

Parking in this area is designed to work as a single system; hence MPRs for these sub-areas are lower to account for the balancing out effect of people parking once and walking to a variety of shops.

The parking policy for the Vehicle Orientated area on the other hand is full on-site provision at each development with limited or no spill-over onto the road network. This is driven by a desire to protect the convenience and efficiency of the road network and to encourage activities in this area that are single destination style activities and ones that require vehicle access. The plan notes that more intensive land use might be restricted in the Vehicle Orientated area as complying with the generous parking standards will not be possible.

MPRs for the CBD are listed in Table 1. Permitted and discretionary activities refer to classifications under the Resource Management Act (1991). A permitted activity requires no resource consent as long as it meets all the necessary rules and standards in the district and regional plans. In the event that a developer wants to provide less parking, than the district plan requires, they may submit a resource consent application and apply for discretionary 
activity status. Discretionary parking standards are $20 \%$ or so lower than permitted standards in each area. Applicants will be required to justify their position based on expert evidence. The decision whether to grant consent is at the discretion of the local authority.

Table 1: Minimum parking requirements in the Porirua CBD zone

\begin{tabular}{|c|c|c|c|}
\hline CBD sub-area & & $\begin{array}{l}\text { Permitted Activity } \\
\text { Standard }\end{array}$ & $\begin{array}{l}\text { Discretionary Activity } \\
\text { Standard }\end{array}$ \\
\hline Inner Pedestrian & & $\begin{array}{l}4.5 \text { parks per } 100 \mathrm{~m}^{2} \text { GFA } \\
\text { (excludes the existing } \\
\text { ground floor) }\end{array}$ & 3.5 parks per $100 \mathrm{~m}^{2} \mathrm{GFA}$ \\
\hline \multirow[b]{2}{*}{ Outer Pedestrian } & All else & 4.5 parks per $100 \mathrm{~m}^{2} \mathrm{GFA}$ & 3.5 parks per $100 \mathrm{~m}^{2} \mathrm{GFA}$ \\
\hline & $\begin{array}{l}\text { Covered mall greater than } \\
30,000 \mathrm{~m}^{2}\end{array}$ & 3.7 parks per $100 \mathrm{~m}^{2} \mathrm{GFA}$ & 3.5 parks per $100 \mathrm{~m}^{2} \mathrm{GFA}$ \\
\hline \multirow{2}{*}{$\begin{array}{l}\text { Vehicle Orientated } \\
\text { area }\end{array}$} & Ground floor & 5 parks per $100 \mathrm{~m}^{2}$ GFA & 4 parks per $100 \mathrm{~m}^{2} \mathrm{GFA}$ \\
\hline & Subsequent floor & 3.5 parks per $100 \mathrm{~m}^{2} \mathrm{GFA}$ & 3 parks per $100 \mathrm{~m}^{2} \mathrm{GFA}$ \\
\hline
\end{tabular}

Source: (Porirua City Council, 1999)

The district plan notes that parking standards have been established through studies and consultation which constitute assessments of the costs and benefits of standards. It does not outline what these studies are. The chief traffic engineer at Porirua City Council indicated in an email that district plan standards were based on Ministry of Transport recommendations (G. Marshall, personal communication, December, 13, 2009).

\subsection{Why Porirua?}

Porirua is my home. I have an affinity for the area and an interest in its long-term development that, in itself, was a motivating reason to use it as a case study. Porirua City was established during a period when car use was rising dramatically. Even at its inception the planning was strongly auto-centric. This might sound like a contradiction of the description of the 'pedestrian focused layout of the original city centre' and its location on the train line. A more telling design feature of the original layout is the number of car parks that were provided. A staggering twelve hundred car parks (1000 for the public and 200 for service vehicles) were installed to supply $320,000 \mathrm{ft}^{2}$ of retail and a number of government and civic buildings (Dudding, 1963). Lane's Master's Thesis (1966) on Porirua's development puts the ratio of parking footprint to building footprint at close to $2: 1$. For every square metre of building there were nearly two square metres of parking; this in an age when public transport use was still high and vehicle ownership rates were around a third of today's level (Dargay, 
Gately, \& Sommer, 2007). Lane, in the same study, makes two further observations about the parking. Firstly, that it was heavily underutilised, which is not surprising given that the level of provision was high even by today's standard. Secondly, somewhat presciently he notes that unless car use is controlled, by means such as priced parking, use of public transport would decline.

The tradition of making sure that Porirua is a car friendly location has continued with the current approach to parking management. All parking is free, and large quantities of on-site parking are encouraged. The apparent reasoning for this is to create a 'point of difference' with other regional centres (T. Kelly \& Incite Ltd, 2006). Minimum parking requirements in Porirua are the primary parking management tool. As land has been cheap and plentiful there is a predominance of surface parking. The factors listed above combine to make Porirua a microcosm of the way in which MPRs impact on development and transport patterns in a car friendly cityscape.

To assess these impacts, a range of data gathering projects were undertaken. These included a parking occupancy study, land use mapping and a stated preference survey.

\subsection{Occupancy study}

A parking occupancy study aims to assess the extent to which car parks are being utilised. At its simplest, it is a count of the number of parked vehicles in a given place at a given time relative to the number of parks available. The counts can be a simple or reasonably complex undertaking depending on the objectives to be met and the resources available. The primary aim of this occupancy study was to assess how efficiently the parking resource (particularly at on-site lots) was being used across the CBD. In line with this, the following two objectives guided the study:

- Quantify the mean and peak occupancy at car parks across the city on the busiest days of a regular week/weekend

- Quantify the percentage of long-stay parkers in off-street customer parking lots

All the car parks in the city centre were mapped prior to the counting days to establish parking categories and car park numbers, and to highlight obstacles. Eight assistants were employed to do the counting and it was carried out over two days, Thursday and Saturday. Counting occurred in the last week of July. 
Choosing when and how many days to count (in occupancy studies generally) is a matter of cost, timing and underlying assumptions about what should be measured. Occupancy studies are often carried out at individual developments as part of a traffic assessment for a resource consent application. Studies with a wider scope, such as a town centre, are more often commissioned by local authorities. Counting on two days (one midweek and one weekend) appears to be a common approach that balances cost with accuracy (see for example T. Kelly \& Incite Ltd, 2006; Sinclair Knight Merz, 2007).

When to count is more controversial. Often as a matter of expediency, occupancy counts are made only when the information is required. As pointed out in the literature review, the traditional traffic engineering approach argues that surveys should measure or account for peak demand. In the case of retail this means seasonal peak demand should be measured. Douglass \& McKenzie (2001) offer a means of extrapolating data, collected during non-peak periods, to account for the Christmas peak. Due to the limited data set that this extrapolation formulae is based on, along with the problems of applying standardised approaches across heterogeneous environments, it is argued that this would tend to inflate supply rates.

Porirua CBD is dominated by retail development, and therefore, peak demand is an important consideration. However, it is only one of many considerations. Equally important are efficiency of parking use and the wider impacts that ample free parking has on land use and trip generation. For these reasons, and those outlined in the literature review, the traditional approach of measuring peak seasonal demand, or extrapolating data to account for it, is rejected. In a market for parking, peak period parking would be priced accordingly, as is the case in air travel during holidays. In the absence of charging a more realistic assessment of the demand for on-site parking are the local mean and peak occupancy levels that occur on a weekly basis during a non-exceptional period of the year. Mean usage, particularly, gives a picture of how efficiently the resource is being used over time given that peak usage can hide low background utilisation rates.

Nevertheless, a conservative approach was taken regarding the days chosen. Porirua City Council carries out occupancy counts within the Inner and Outer Pedestrian areas in the first week of October every year. For comparability with council records Thursday was chosen for this study as it is the day with the highest overall parking demand. Likewise, a Saturday 
during the first week of the school holidays was selected. Holidays often experience higher than average demand (Douglass \& McKenzie, 2001). Selection of these days is likely to lift the measured occupancy rate above the weekly average, so maintaining an upward bias in the measured rate.

Other issues potentially impacting on parking demand during this study were weather, season and the economic downturn. The weather was fine on both days of the count. During the first quarter of 2009 retail sales figures fell by $1.2 \%$ (NZPA, 2009). Comparing the occupancy data from this study with other local studies provided a means of gauging whether season and recession had impacted significantly. This study showed occupancy rates similar to the council records. Comparison with a limited city-wide occupancy study from July 2005 (T. Kelly \& Incite Ltd, 2006) showed occupancy rates in the present analysis were higher.

The time of day can affect occupancy rates so counts were started at $8 \mathrm{am}$ and finished at $4 \mathrm{pm}$. Counts were made throughout the day on the hour, and during peak period on the half hour as well. The long-stay parking component was assessed by recording the number plates (the first three digits) of cars parked before $9 \mathrm{am}$ and then rechecking those vehicles at $2.30 \mathrm{pm}$. The long-stay component was measured on privately owned customer parking lots and public unrestricted parking areas. Reserved parking around commercial buildings and behind businesses was assumed to be long-stay.

In other respects, the counting procedure was standard. Counters were allocated a circuit which they retraced on the hour or half hour. Counters were given detailed maps of their route and lot layout for those areas where long-stay parking was measured. Counting procedures were standardised so that results would be consistent across the city.

\subsection{Geographical Information Systems: Mapping the CBD}

The second data gathering exercise was to assess the proportion of Porirua's CBD land allocated to parking. Geographical Information Systems (GIS) are a powerful mapping tool that can be used to assess land use patterns. Using high definition aerial photographs of the Porirua CBD the land area devoted to parking was quantified, including kerb-side parking spaces. Much of this work was carried out by the GIS department at Porirua City Council. Some refinements and additions were made to the initial data set. The CBD is a relatively 
small area so the whole area could be mapped without the need to sample, as in other studies (see for example Akbari, et al., 2003).

Parking areas with no through-access were mapped in their entirety, including the circulation and access road. Areas that were predominantly loading zones were omitted even if some parking was also located in the vicinity. Parking lots at car sales yards were omitted.

\subsection{Stated choice survey}

The last data gathering exercise was a stated choice survey of commuters to the CBD. Parking is free in Porirua. An assessment of the optimal parking supply requires an investigation of parking demand with respect to price. Beyond an approximation based on the literature, it is unknown how price would affect demand for parking and travel behaviour in Porirua's specific case. The literature notes that the relationship between parking price, parking demand and travel behaviour are complex and influenced by location-specific variables (Marsden, 2006). Hence, to understand how commuters in Porirua would respond to a parking price a stated choice survey was carried out.

Stated choice surveys are part of a wider set of modelling tools used in econometrics to understand behaviour and illicit consumer's preferences and willingness to pay. A brief explanation of their role, the theoretical underpinnings and design steps follows.

\section{Why survey}

Many goods and services that society uses and values have no market to 'reveal their monetary value'. In these situations economists require a different set of tools. Broadly they are known as non-market valuation and fall into two categories: revealed preference and stated preference. Revealed preference techniques use observed purchase decisions to infer the value of an unpriced good. For instance, the value of 'a view' can be deduced from the price people are willing to pay for a house with a view versus an identical one without.

Even when a market is present, consumer purchasing information often provides little insight into the many factors that influence a final choice. For instance, $12 \%$ of Wellington commuters pay to go by train to work. This information provides no insight as to the relative roles that traffic congestion, the cost of parking and the price of rail tickets have on the final choice to commute by rail. When the information does not allow the various explanatory factors to be isolated it is said to be co-linear. A further limitation of revealed preference data 
is the inability to measure demand under conditions which do not yet exist (Kroes \& Sheldon, 1988). Stated preference methods offer an alternative approach in these situations.

Stated preference methods essentially ask a consumer to state their preference and/or willingness to pay for a set of goods and services (Kroes \& Sheldon, 1988). They came to public prominence, controversially, with the Exxon Valdez oil spill in 1989. A stated preference method was used to calculate the damages caused to the environment and local communities. Residents were surveyed on their willingness to pay for the 'environmental services' that had been damaged in the spill.

Since the advent of stated preference methods, the field has been refined and added to. Discrete Choice modelling, which this research draws on, is one such addition. Choice modelling typically invites respondents to indicate what they would do if they were faced with the choices described to them (Mathews, Freeman, \& Desvousges, 2007). The purpose of such an approach is to determine the influence that each of the different variables has on the decision outcome (Rose \& Bliemer, 2009). The researcher can manipulate both the number of available choices and the attributes of the choice scenario. For example, a respondent might be provided with two transport options, taking the bus or using the car. Added to this might be a range of parking prices and travel times. This approach offers a wider range of statistical information than available in earlier methods giving rise to greater predictive ability and a more robust understanding of behaviour. It is also argued that this approach more closely resembles what consumers are faced with in everyday life (Hensher, Rosie, \& Greene, 2005).

\section{Theory base}

The wider field is grounded in utility maximisation theory (Hensher, et al., 2005) which in turn derives from neoclassical economic thought. Consumers are assumed to act rationally, with perfect information, to maximise the benefits from each purchase decision (Adamowicz, et al., 2004). Random utility theory (which informs discrete choice modelling) further assumes that in choosing an alternative the consumer maximises the relative utility arising from that alternative's combined characteristics (Hensher, et al., 2005). What is observed in a consumer's choice is the sum of an observable and a random utility component. The random component results from the unknown influences on consumer decisions that cannot be measured and accounted for. For all the strengths of this approach, as a singular model for 
understanding transport decisions, it has limitations (Poudenx, 2008; Richardson \& Stern, 2005).

\section{Survey limitations}

Despite the best intentions, choice modelling is subject to hypothetical bias (Hanley, Shogren, \& White, 2007; Mathews, et al., 2007). Respondents are not faced with the true consequences of their choices, and this may distort stated values away from true values. For example, external validity studies of contingent valuation (a stated preference method) have highlighted this problem (Harrison, 2007). The extent of this bias and the ability to mitigate it is the subject of much discussion (Bennett \& Rolfe, 2006; Carlsson \& Martinsson, 2001). In the transport field the presence of empirical studies on travel demand offers a counterbalance to claims derived from hypothetical data. Surveys generally, are also subject to behavioural distortions such as information bias, strategic bias, and survey fatigue. The potential effects of these actions can be reduced and mitigated through careful design and larger sample sizes (Hensher, et al., 2005; Kroes \& Sheldon, 1988).

\section{Design steps}

Stated choice surveys require careful design and lay-out to ensure they are user friendly and statistically valid (Carlsson \& Martinsson, 2001). The following design steps are based on Mansfield \& Pattanayak (2007) and Adamowicz et al. (2004).

1. Defining the problem

As there is currently no market for parking in the Porirua CBD, the survey investigates how price would affect demand for parking and travel behaviour.

2. Defining the alternatives and the attributes to be explored

Choice experiments involve respondents making a trade-off between two or more options in a real world context. A bulky survey (with many alternatives and attributes) increases respondent fatigue (Krupnick \& Adamowicz, 2007) whereas few alternatives and attributes can reduce the predictive power of the model. In this study three alternatives and six attributes were presented to respondents. These were chosen as they represent the essential choices facing Porirua commuters. They were: park in the CBD and pay a price $(\$ 0, \$ 3$ or $\$ 6)$; park outside the CBD for free but incur a walk time (5,10 or 15 minutes); change mode of travel. Price, walk time and mode change were chosen because they are cited in the literature as important influences on the demand for parking (Hensher \& King, 2001; Rye, et al., 2004; 
Shoup, 2005). They are not the only variables influencing demand for parking but it was important to keep a simple and user friendly instrument to ensure return rates were not compromised (Kroes \& Sheldon, 1988). Attribute levels were evenly spaced $(\$ 0, \$ 3, \$ 6)$ and wider, rather than narrower, in range (Rose \& Bliemer, 2009).

\section{Sampling}

The sample population was commuters who currently park within the CBD for free. Business owners who commute and park behind their shop were omitted as they theoretically cover the cost of their parking in the rent they pay. Including them could have resulted in hypothetical bias (Bennett \& Rolfe, 2006) as they have little incentive to charge themselves a parking fee. Without this group there are around 800 to a 1000 long stay parkers in the CBD. Polytech parking makes up close to 400 of these. As this group are largely students, and assumed to be on low incomes, they had the potential to skew the results. Income is correlated with parking demand (A. J. Kelly \& Clinch, 2006) and the survey collected no income information to measure this effect. Hence, only a sample of cars parked at the Polytech were allocated questionnaires. Six-hundred and fifty questionnaires were distributed on windscreens in areas of long-stay parking that had been identified during the occupancy study. All unrestricted public parking was covered along with large private customer lots known to contain higher numbers of long-stay users. Questionnaires were dropped on a week day before 9.00 am to reduce the chance of sampling other trip purposes.

4. The survey design and model estimation

Stated choice surveys are specifically designed to be used in discrete choice models. The approach used in the design of this survey is based on the work of Huber and Zwerina (1996) and Rose and Bliemer (2009). These types of stated choice surveys are known as 'efficient' designs and are optimised based on assumptions about the likely parameter values that will be available from the data in the main survey and the type of multinomial logit model that will be used to estimate the parameter values. In this case the multinomial logit model used was a panel data form of a random parameters model. Efficient design, compared to more traditional design approaches such as 'orthogonal design', reduces the sample sizes needed for statistical significance while enhancing a model's performance by reducing the standard errors to as low as possible (Rose \& Bliemer, 2009). It is beyond the scope of this study and my statistical and econometric skills, to describe the merits and limitations of the various modelling approaches.

5. Pre-testing the survey

A pilot run of the questionnaire, which included nine choice scenarios, was presented to ten participants. The scenarios were randomly assorted to prevent information bias (A. J. Kelly \& 
Clinch, 2006). Results from the pilot highlighted the supporting information needed to orientate participants as well as producing prior parameter estimates for the main effects of price and walk time. Parameters are the relative influence each variable has on a choice outcome. These were required for the efficient design stage. 


\section{Data Analysis}

This section discusses the research findings. Data from the occupancy study is dealt with first. MPRs as an allocation mechanism are examined in the light of car park occupancy. This is explored from a number of angles, including mean utilisation, peak utilisation, comparisons with the district plan requirements and wider spatial provision.

Following this a full cost recovery model for CBD parking is estimated along with some discussion as to how price might impact on parking demand for various trip purposes. The results from the stated choice survey follow next and examine how price impacts on commuter parking demand and travel behaviour. Lastly, the impact that parking has on land use patterns in the CBD is presented in graphical form.

\subsection{Occupancy data overview}

Figure 5 on the following page, is an aerial photograph of the CBD with the various sub-areas highlighted. The CBD zone boundaries, as defined by the district plan, are shown in dark blue. This research confined the CBD to the natural boundaries of the harbour, the stream and the arterial roads to the west and south. Although this had no impact on the occupancy study, it does have a bearing on the land use exercise. This is discussed later. The area highlighted in orange at the southern end of the city was not included in the occupancy study and is part of the Outer Pedestrian (OP) area. This area was omitted because it is not part of the natural traffic circulation in the $\mathrm{CBD}$, has a number of vacant premises and research resources were limited. 


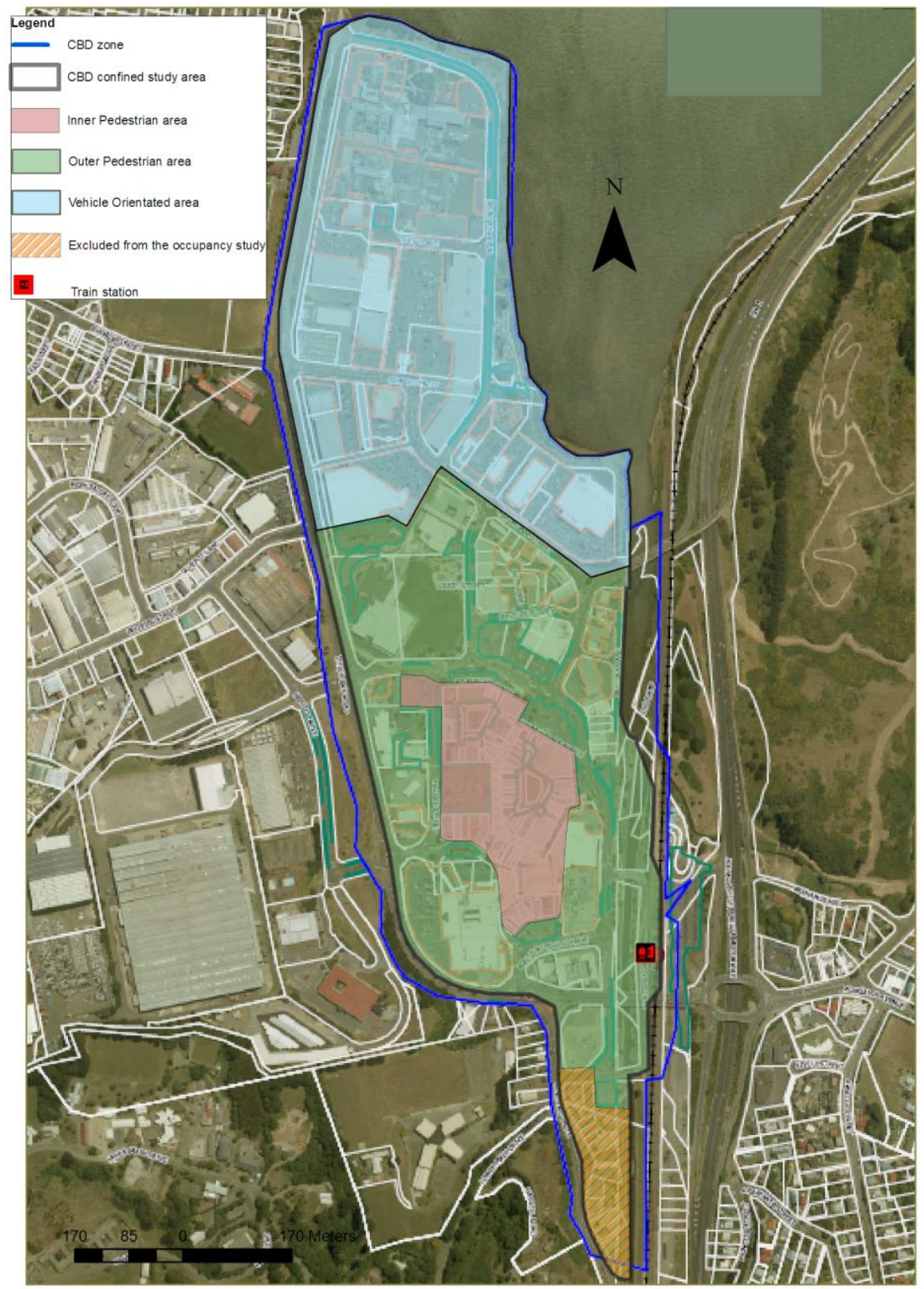

Fig. 5: CBD zone, sub-areas and portion excluded from the occupancy study Source: Adapted from GIS map 'Porirua City Centre Public \& Private Car Parking Spaces' (Porirua City Council)

\section{Data limitations}

- The number of car parks was assessed at around 5700. The wider stock is around 5850. There is a margin of error in the total count as reserved parking behind developments was often unmarked. Car park numbers in these areas were based on the number of cars parked at the site at peak times.

- Occupancy rates at the educational institute and surrounds (north end CBD) seemed unusually low on the Thursday count as this coincided with the end of the institute's 
term. A subsequent count in the following term found this to be the case and the first set of data was adjusted.

- There is a small amount of missing data. It concerns one parking lot and had no impact on establishing peak occupancy

For comparative purposes parking was grouped into six categories. The terms public and private do not necessarily correlate to land ownership as the council owns a portion of privately leased parking. Private customer and private reserved primarily distinguish customer parking from owner/employee parking. Occupancy rate and parking demand are used interchangeably. Where demand is used it refers to demand for 'free parking'.

\subsection{Occupancy data: Mean utilisation rates}

Table 2: Mean car park availability and occupancy by category and day

\begin{tabular}{|c|c|c|c|c|}
\hline \multirow[t]{2}{*}{ Park category } & \multirow{2}{*}{$\begin{array}{l}\text { Total available } \\
\text { parks }\end{array}$} & \multirow[t]{2}{*}{ Percentage of total } & Thursday & Saturday \\
\hline & & & Mean occupancy & Mean occupancy \\
\hline Public on-street unrestricted & 473 & $8 \%$ & $76 \%$ & $25 \%$ \\
\hline Public off-street unrestricted & 373 & $7 \%$ & $68 \%$ & $20 \%$ \\
\hline Public on-street time limited & 263 & $5 \%$ & $69 \%$ & $48 \%$ \\
\hline Public off-street time limited & 322 & $6 \%$ & $79 \%$ & $40 \%$ \\
\hline Private off-street reserved ${ }^{1}$ & 583 & $10 \%$ & $70 \%$ & $23 \%$ \\
\hline Private off-street customer & 3682 & $65 \%$ & $45 \%$ & $35 \%$ \\
\hline
\end{tabular}

Source: Own data

${ }^{1}$ A portion of this stock is owned by the council and leased to local businesses

Table 2 highlights two points in relation to MPRs. Firstly, MPRs as the primary parking management tool have resulted in a transfer of ownership from public to private hands. The current stock of around 5850 car parks is a substantial increase on the 1,200 car parks provided when the city was first established (Lane, 1966). Around $68 \%$ of the total stock is now in private ownership. The change in ownership has been dramatic. Up until the 1980s car parking was largely owned and managed by the council. This has implications for the council's ability to manage the resource in the future (T. Kelly \& Incite Ltd, 2006). 
Secondly, parking supplied under MPRs has relatively low mean utilisation rates. The MPRs component is represented by the private off-street customer category. This is spread across developments in the OP and Vehicle Orientated (VO) sub-areas. A mean occupancy of $45 \%$ on Thursday suggests the resource is underutilised on week days. This is not surprising as MPRs are set to meet peak demand profiles, as infrequent and short lived as they are (Shoup, 2005). Saturday's rate of 35\% highlights this. Most of the developments experienced their peak occupancy rates on this day, yet the mean occupancy rate is lower. Peak occupancy rates are not high, and in addition they hide lower background utilisation rates.

By way of comparison the public off-street time limited category represents a similar parking resource, except it services retail and commercial development in the Inner Pedestrian (IP) sub-area. At 79\% mean occupancy this parking resource is used almost twice as efficiently as the private off-street customer parking. This is not surprising as the parking in this category works on a shared basis to supply a much greater density of commercial and retail development. This parking arrangement and supply rate would no longer be possible under the current district plan standards.

\subsection{Occupancy data: Peak rates}

A sample (90\%) of the private customer parking category was assessed for how efficiently the parking resource was being used at peak periods. Peak occupancy occurs at different times depending on the land use type. The two day count endeavoured to cover these variations. In the case of the recreation centre this was not possible as peak usage coincides with special events. The methodology chapter above details how the occupancy count was organised.

In Figure 6 on the following page, the peak occupancy at developments in the CBD with more than five on-site customer car parks is shown in green. The percentage of spaces occupied by long-stay (greater than 5hrs) parkers is also shown in red. 


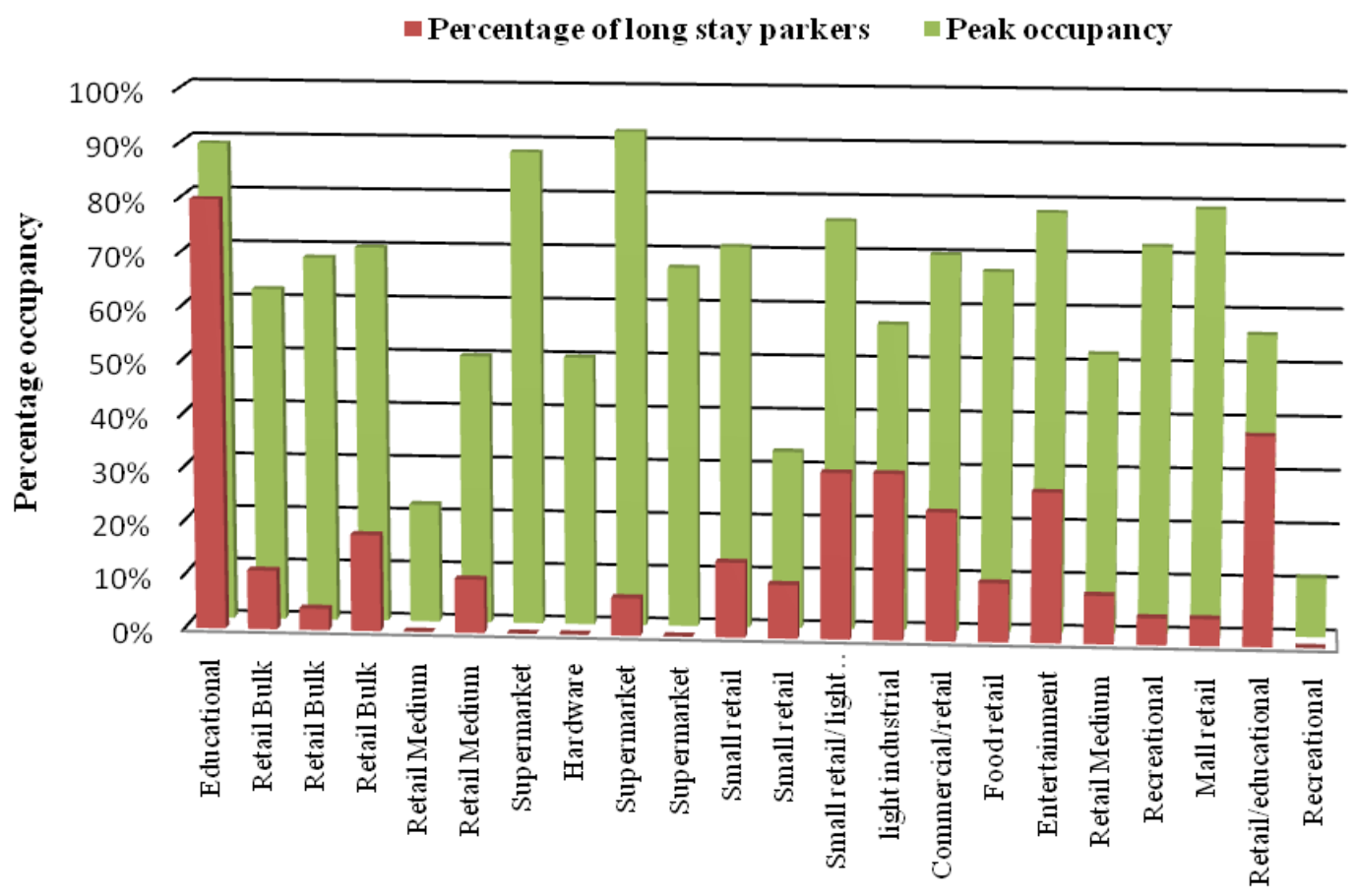

Individual development categorisation

Fig. 6: Peak occupancy by development (percentage occupancy rates for developments with more than five off-street carparks and percentage of car parks occupied by long stay users) Source: Own data

The following analysis uses the Institute of Transportation Engineers (2004) '90\% occupied rule' to define a car park as technically full.

Figure 6 highlights two points in relation to the efficiency of parking use at peak. Firstly, there is an obvious underutilisation across most of the parking resource. Only three of the 22 developments had technically full car parks at peak and the supermarket that exceeded $90 \%$ occupancy suffers from the 'free rider' problem'. This car park serves a development that sits at the opening to a large covered mall and adjacent to a heavily utilised public car park. High levels of parking enforcement (for Porirua) are employed at the site.

The average peak occupancy across the developments is $62 \%$. Average spare capacity, therefore, stands at around $30 \%$.

\footnotetext{
${ }^{9}$ Free riders in this case are people using the development's car park to shop at other locations.
} 
Secondly, long stay parking consumes between four and 30\% of the available parking resource. The educational institute is excluded from this analysis as it is almost exclusively long-stay. On average long-stay parkers use $12 \%$ of the parking resource (at the time of survey), but a substantially higher percentage of the total parking capacity when turnover rates are factored in. These figures are conservative as not all the long-stay parking component on all development sites was assessed.

To compare actual parking demand with the district plan standards the peak occupancy rate is expressed as 'car parks occupied per $100 \mathrm{~m}^{2}$ of GFA'. The district plan standards for each of the CBD sub-areas was provided in the methodology section.

\section{Peak rates per $100 m^{2}$ of $G F A$}

Conversion requires GFA figures for each development. This information was gleaned from resource consents and some was supplied by Quotable Value ${ }^{10}$. Figure 7 on the following page, shows the peak occupancy figures from 21 sites expressed as 'occupied car parks per $100 \mathrm{~m}^{2}$ of GFA'. Because the district plan standards vary by sub-area, the occupancy rates are juxtaposed against the two parking standards applicable for the sub-area they are located in.

This analysis considers peak occupancy minus the long-stay parking component (where this was present and not in the case of the educational centre). The reasoning is as follows:

- Long-stay parking contravened the resource consent of a number of sites and was not permitted on several others

- Long-stay parking is an inefficient use of customer parking that inflates the occupancy rate. In line with the Regional Land Transport Strategy (2007) it is better managed through other mechanisms

- It had little impact on the peak occupancy rates of all but two sites

\footnotetext{
${ }^{10}$ Quotable Value is a private company that provides “a range of property reports and valuations" http://www.qv.co.nz/
} 


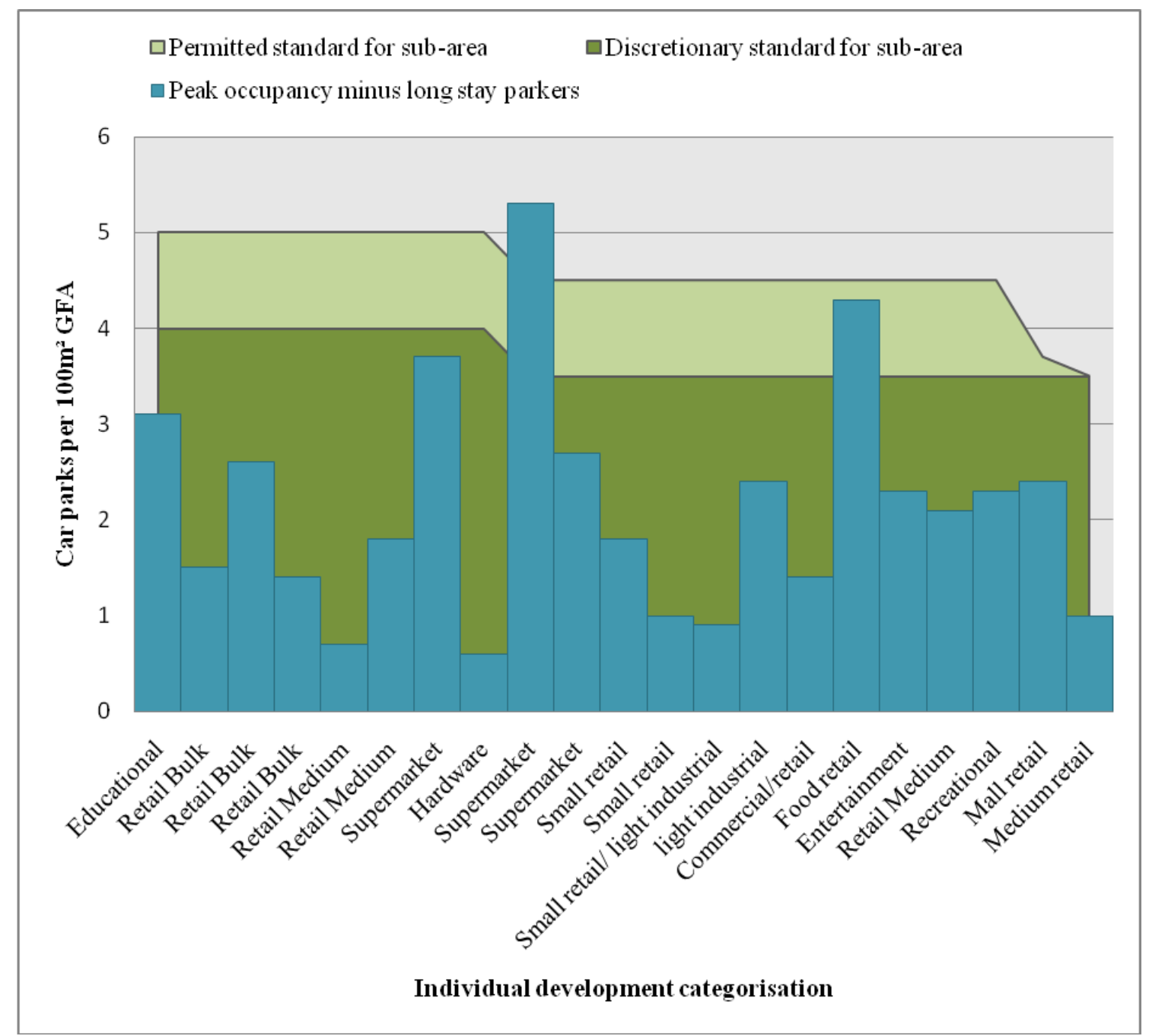

Fig. 7: Peak parking occupancy relative to standards Source: Own data

Figure 7 shows that the district plan standards for the various sub-areas bear little relationship to the peak occupancy rates at development sites. Only one site out of 21 has a peak occupancy ratio that is higher than the permitted standard. This is the supermarket described in the previous section. All other sites bar one fall below not only the permitted but also the discretionary standard. This inflates parking supply in two ways.

Firstly, if a developer supplies at the permitted rate (either by choice or to avoid the compliance costs associated with a resource consent), oversupply is highly probable. In many cases it will be a gross oversupply. Secondly, if a developer wants to reduce parking provision on the basis of expert evidence the generous standards in the district plan will tend to drive up any compromise negotiated with the council or at the environment court. 
This was apparent in a number of the resource consents inspected as part of the background research. Two examples are as follows.

A bulk retail development in the VO sub-area required a resource consent for non-compliance with the parking standards (amongst other things). The submitted traffic report said a rate of 2.3 parks per $100 \mathrm{~m}^{2}$ of GFA would suffice, based on a similar and recent development in Auckland (RC1628, Porirua City Council, 1998 - 2006). The permitted and discretionary standards for the sub-area are five and four per $100 \mathrm{~m}^{2}$ of GFA respectively. Parking was eventually supplied at a rate of 3.54 per $100 \mathrm{~m}^{2}$ of GFA, significantly more than the level in the best available evidence.

A traffic assessment of this site carried out some three years later concluded that, "It is apparent that there is such a high level of over-supply of parking it could indeed be considered that the large area of car parking relative to retail premises represents an inefficient use of valuable resource" (RC1710, Porirua City Council, 1998 - 2006).

In a similar vein, a traffic report submitted for a commercial/retail development in the OP sub-area suggested that 25 parks would be appropriate (RC1862, Porirua City Council, 1998 2006). The permitted standard required 48 parks; 33 were supplied.

Figure 7 also highlights the variance in occupancy rates between similar land uses. This suggests that the relationship between GFA and parking occupancy is weak, a point hammered home by Shoup (2005). As the wider industry continues to use GFA as a principal predictive variable, the efficacy of this relationship is further explored below.

\subsection{Correlation between parking demand and gross floor area}

Occupancy survey data available in Parking and Trip Generation Surveys (NZ Trips \& Database Bureau Inc, 2009) provides a larger sample size than the current study. Much of this data comes from Transfund Reports 209/ 210 (Douglass \& McKenzie, 2001), whose authors claim that the data does not warrant close statistical analysis. This is presumably due to the variation among the days and years when surveys were recorded and the variation in collection methodology. Given these provisos, it is not clear why the relationship between GFA and parking occupancy has not been explored further. Shoup (2005) notes that poor quality data has not stopped other publications from using the claimed relationship as the basis for suggested parking rates. It could be that the authors of Reports 209/ 210 were trying 
to avoid the same pitfalls. However, within the Report 209 the authors suggest retail parking rates based on GFA. Further, GFA is the predictive modus operandi for New Zealand parking regulations nationwide.

Data in Figure 8 comes from occupancy studies at small retail developments (less than $5000 \mathrm{~m}^{2}$ ) that are predominantly suburban. The data has two serious weaknesses as it spans six plus years, and it does not necessarily reflect weekly or seasonal peaks, so individual observations are not necessarily comparable. However, it may be argued that parking demand has changed little over the decade (Douglass \& McKenzie, 2001); hence, the impact of the time span should be limited. The second issue is problematic. To mitigate this factor, where multiple counts for an individual site were provided, the highest surveyed occupancy rate was chosen.

Figure 8 is a regression analysis that explores the degree of correlation between GFA and parking occupancy rates. The $\mathrm{R}^{2}$ value expresses the level to which occupancy rates are explained by the gross floor area of the building. An $\mathrm{R}^{2}$ of 0.168 suggests that around $17 \%$ of the parking demand at small retail sites can be explained by GFA. If this analysis is at all reliable GFA is a reasonably poor predictor of parking demand. This finding concurs with Shoup's (2005) assessment of GFA as a predictive variable.

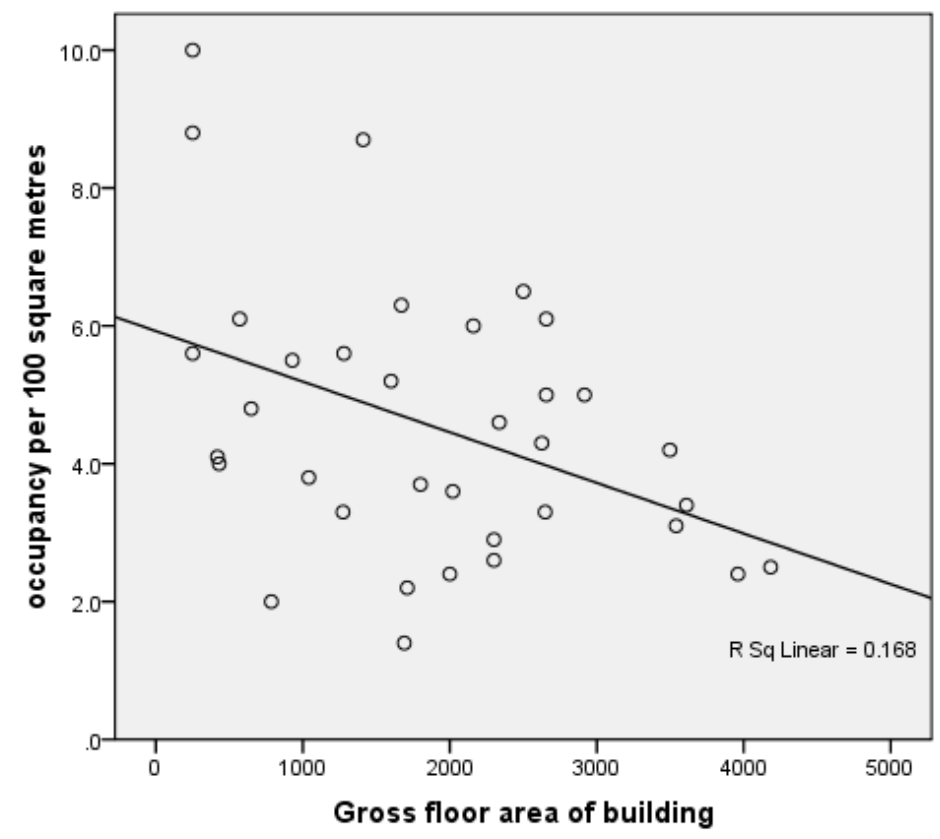

Fig. 8: The relationship between GFA and parking occupancy (peak occupancy at small retail developments plotted against gross floor area)

Source: Parking and Trip Generation Surveys (NZ Trips \& Database Bureau Inc, 2009) 


\subsection{Occupancy data: Parking supply at the walkable scale}

MPRs mandate parking at each and every development. Instead of 'park once and walk' they encourage 'park everytime'. City centres, however, are usually places of high population density, compact form and mixed-use. Many facilities are accessible within a small walking radius, therefore it is appropriate to plan development (including parking provision) at the human scale (Litman, 2006; Mumford, 1961). The following analysis looks at the efficiency of parking provision near several developments when a walkable scale of $200 \mathrm{~m}$ is applied. As noted earlier, the original city lay-out (IP sub-area) was designed to promote pedestrian movement by the separation of traffic and the use of shared parking. Later development has been dominated by parking at each and every site, although many of the on-site car parks serve multiple businesses within the development site.

The supply of parking around each development was measured by taking two radius measures, $100 \mathrm{~m}$ and $200 \mathrm{~m}$, from the centre of each development's car park. Measurements coincide with peak demand at each of the developments. The samples were three retail and one recreational development from two sub-areas. Two hundred metres was chosen as a walkable distance for a number of reasons:

- Walking distances within some of the bigger car parks can be up to $200 \mathrm{~m}$

- $200 \mathrm{~m}$ is conservative in the literature. Evidence from pedestrian focused cities, and new urban design principles, show a willingness to walk distances well in excess of this (Stubbs, 2002; Zacharias, 2001)

- The distance that customers are willing to walk is related to their duration of stay (Carley cited in Litman, 2006). Carley suggests 1 hour equates to $200 \mathrm{~m}$ and the average duration of stay at Porirua's outer retail sites is around 80 minutes (T. Kelly \& Incite Ltd, 2006)

Three aspects of the wider parking supply were quantified. They were: available car parks (private and public) within 100m, available car parks (private and public) within 200m, and available public car parks within $200 \mathrm{~m}$. Findings are presented in Table 3 on the following page. 
Table 3: Wider parking supply for a range of developments

\begin{tabular}{|c|c|c|c|c|c|c|c|}
\hline $\begin{array}{l}\text { Land use } \\
\text { category }\end{array}$ & $\begin{array}{l}\text { Peak occupancy } \\
\text { at the } \\
\text { development's } \\
\text { onsite car park }\end{array}$ & $\begin{array}{l}\text { car parks } \\
\text { within } \\
100 \mathrm{~m}^{1}\end{array}$ & $\begin{array}{l}\text { car parks } \\
\text { within } \\
100 \mathrm{~m} \\
\text { as } \% \text { of } \\
\text { onsite } \\
\text { total }\end{array}$ & $\begin{array}{l}\text { car parks } \\
\text { within } \\
200 \mathrm{~m}^{1}\end{array}$ & $\begin{array}{l}\text { car parks } \\
\text { within } \\
200 \mathrm{~m} \\
\text { as \% of } \\
\text { onsite } \\
\text { total }\end{array}$ & $\begin{array}{l}\text { public car } \\
\text { parks } \\
\text { within } \\
200 \mathrm{~m}\end{array}$ & $\begin{array}{l}\text { public car } \\
\text { parks as \% } \\
\text { of onsite } \\
\text { total }\end{array}$ \\
\hline Bulk retail & $68 \%$ & 17 & $3 \%$ & 290 & $50 \%$ & 73 & $11 \%$ \\
\hline $\begin{array}{l}\text { Recreation } \\
\text { centre }\end{array}$ & $71 \%$ & 21 & $9 \%$ & 282 & $100 \%$ & 60 & $27 \%$ \\
\hline $\begin{array}{l}\text { Small } \\
\text { retail }\end{array}$ & $81 \%$ & 7 & $33 \%$ & 50 & $100 \%$ & 7 & $33 \%$ \\
\hline $\begin{array}{l}\text { Covered } \\
\text { mall }\end{array}$ & $79 \%$ & 95 & $9 \%$ & 536 & $50 \%$ & 270 & $25 \%$ \\
\hline Average & & & $13 \%$ & & $75 \%$ & & $24 \%$ \\
\hline
\end{tabular}

Source: Own data

${ }^{1}$ These car parks are over and above the development's on-site car park supply

Results indicate that when the parking supply is scaled to $100 \mathrm{~m}$ modest reductions in the development's on-site provision could be made. At 200m, however, the reductions are substantial, amounting on average to $75 \%$. Efficiency gains could also be made by placing a greater reliance on available public parking. While parking provision could obviously be scaled down, the exact extent is dependent on how many developments in a given area are clustered to take part, their size and type, and what assumptions are made about walkable distances.

\subsection{Parking cost recovery model}

For parking to be allocated at the optimal level it must be priced. The efficient amount is determined when the price consumers are willing to pay is equal to the marginal cost of supplying the car park. In the case of bundled parking, this might be argued to be the cost less the net-benefit of attracting an extra customer. The following analysis estimates a cost recovery model for CBD parking. Dollar figures are expressed as '2007 dollars'. Adjustments were made using price movements within the land transport section of the producer's price index ${ }^{11}$. Calculating the cost of transport infrastructure is controversial (Booz Allen Hamilton,

\footnotetext{
${ }^{11}$ http://www.stats.govt.nz/browse_for_stats/economic_indicators/prices_indexes/producerspriceindex_hotpjun09qtr.aspx)
} 
2005) and costings can vary significantly depending on the assumptions and methodology applied. The assumptions used in this analysis are presented below.

The principal cost in surface lots is the price of land. Rating information from 2007 was used to calculate average land values for the three CBD sub-areas. Land area devoted to car parking was determined using Geographic Information Systems. Land was assumed to have an opportunity cost. Typically, surface parking is considered to have no value as the costs are sunk (Litman, 2006). However, land has an opportunity cost based on its next most productive use. In the case of an on-site car park this would be extra retail or commercial space. For public off-street lots this might be a recreation area.

Kerb-side parking was removed from the analysis as it is not readily available for alternative uses. While this is not strictly true, as it can be used to widen footpaths and provide bike lanes, the main focus is on parking supplied under MPRs.

The cost of surface park infrastructure was determined by ringing two road surfacing companies. There is one structured (non-surface) car park in the CBD. To establish an infrastructure cost for this, figures cited in Kelly's (2006) parking report were used. These 2005 figures ranged from $\$ 11,000-20,000$ per park and are in the ball park of structured parking costs in the U.S. (Litman, 2009c). A midway figure from Kelly's report was chosen for the analysis below and expressed in 2007 dollars. Two different capital cost assumptions are applied in this analysis to provide an indicative cost range for land; one fairly conservative and the other in line with cost analyses in the literature.

They are:

1. The relevant opportunity cost of capital is the current risk free real rate of return $(5.5 \%)^{12}$ with land values, in a steady state economy, assumed to keep pace with inflation. No term applied

2. The relevant opportunity cost is the weighted average real cost of capital for property companies (6.9\%) with a term period of 20 years. This follows Litman's (2009c) and Willson's (1995) approach to calculating annualised parking costs.

\footnotetext{
${ }^{12}$ http://www.pwc.com/en_NZ/nz/cost-of-capital/cost-of-capital-june-2009.pdf
} 
Table 4 shows the working and results.

Table 4: Cost recovery model for parking

\begin{tabular}{|c|c|c|c|}
\hline City Centre sub-area & $\begin{array}{l}\text { Inner } \\
\text { Pedestrian }\end{array}$ & Outer Pedestrian & $\begin{array}{l}\text { Vehicle } \\
\text { Orientated }\end{array}$ \\
\hline Average land value (\$million per hectare) ${ }^{1}$ & 9 & 5.2 & 3.3 \\
\hline $\begin{array}{l}\text { Total area devoted to parking net of kerb component } \\
\left(\mathrm{m}^{2}\right)\end{array}$ & 15249 & 60702 & 73126 \\
\hline Total land value of parking area (\$ millions) & $\$ 13.72410$ & $\$ 31.56504$ & $\$ 24.13158$ \\
\hline Number of car parks (net of kerb parking) & 550 & 2771 & 2069 \\
\hline Land value per park & $\$ 24,953$ & $\$ 11,391$ & $\$ 11,663$ \\
\hline Annualised cost of land (5.5\%) & $\$ 1,372$ & $\$ 626$ & $\$ 639$ \\
\hline Annualised cost of land (6.9\% / 20 years) & $\$ 2,304$ & $\$ 1,056$ & $\$ 1,080$ \\
\hline $\begin{array}{l}\text { Infrastructure costs per park ( } \$ 60 \text { per } \mathrm{m}^{2} \text { surface parking } \\
\text { and } \$ 18,221 \text { per space for structured parking) }\end{array}$ & $\$ 1,664$ & $\begin{array}{c}\$ 1783 \text { (1503 surface } \\
\text { parks) }\end{array}$ & $\$ 2,121$ \\
\hline Annualised infrastructure cost (6.9\% / 20 years) & $\$ 153$ & $\begin{array}{c}\$ 871 \text { (averaged } \\
\text { across surface and } \\
\text { structured) }\end{array}$ & $\$ 199$ \\
\hline $\begin{array}{l}\text { Annual operational cost per park (lighting, cleaning, } \\
\text { enforcement etc) }\end{array}$ & $\$ 50$ & $\$ 50$ & $\$ 50$ \\
\hline $\begin{array}{l}\text { Monthly cost recovery per car park at (5.5\% annualised) } \\
\text { cost of land }\end{array}$ & $\$ 131$ & $\$ 129$ & $\$ 74$ \\
\hline $\begin{array}{l}\text { Monthly cost recovery per car park at ( } 6.9 \% \text { / } 20 \text { years) } \\
\text { annualised cost of land }\end{array}$ & $\$ 209$ & $\$ 165$ & $\$ 111$ \\
\hline Hourly cost recovery charge per park (based on $40 \mathrm{hrs}$ ) & $\$ 0.80-\$ 1.30$ & $\$ 0.80-\$ 1.00$ & $\$ 0.50-\$ 0.70$ \\
\hline
\end{tabular}

Source: Own data except where referenced in table and covered in preceding paragraph

${ }^{1}$ (http://www.pcc.govt.nz/A-Z-Services/Rates/Property-Valuations)

2 (Litman, 2009c)

Table 4 highlights that even surface parks have a substantial hidden cost. Leaving aside the additional expense that would be incurred with parking meters and compliance, the hourly charge necessary to recover costs ranges from 50 cents to one dollar thirty. This figure is conservative as it assumes that each car park is fully utilised across the day which the preceding analysis has shown is not the case. Not to be charged for this is a boon for drivers. 
To get an idea of how this influences travel decisions the cost recovery price for parking is compared to the average variable cost of a commute and shopping trip. The New Zealand Household Travel Survey provides information on average trip length. Values for the Wellington region were supplied by Lynley Povey from the Ministry of Transport (personal communication, October, 15, 2009). The mean one way distance travelled for shopping trips is $6.7 \mathrm{~km}$ and to work is $12.5 \mathrm{~km}$.

The cost of driving a car involves a fixed and variable component. Variable costs (petrol and tyres and maintenance) influence the day to day decision about whether to drive or not. The fixed cost (purchase price, registration) must be paid regardless. The average variable cost of driving a car in New Zealand has been estimated at $\$ 0.221 / \mathrm{Km}$ (Booz Allen Hamilton, 2005), adjusted to 2007 dollars. Using this figure and the hourly cost recovery parking price the relative value of free parking to a given trip purpose is estimated in Table 5.

Table 5: Cost recovery price of parking as percentage of trip cost

\begin{tabular}{|l|l|l|l|l|l|}
\hline Trip type & $\begin{array}{l}\text { Mean distance } \\
\text { round trip }\end{array}$ & $\begin{array}{l}\text { Average } \\
\text { variable cost of } \\
\text { trip } \\
(\$ 0.221 / \mathrm{km})\end{array}$ & $\begin{array}{l}\text { Length } \\
\text { of } \\
\text { parking } \\
\text { stay }\end{array}$ & $\begin{array}{l}\text { Cost recovery price } \\
\text { of parking for } \\
\text { parking duration } \\
(\text { range })\end{array}$ & $\begin{array}{l}\text { Cost recovery } \\
\text { parking price as a } \\
\text { percentage of trip } \\
\text { cost (range) }\end{array}$ \\
\hline Shopping trip & $13 \mathrm{~km}$ & $\$ 2.90$ & $2 \mathrm{hrs}$ & $\$ 1.00-\$ 2.60$ & $34 \%-90 \%$ \\
\hline Commute trip & $25 \mathrm{~km}$ & $\$ 5.50$ & $7 \mathrm{hrs}$ & $\$ 3.50-\$ 9.10$ & $64 \%-165 \%$ \\
\hline
\end{tabular}

Source: own data, (Ministry of Transport, 2008) \& (Booz Allen Hamilton, 2005)

Cost recovery pricing would add significantly to the cost of travel, particularly commuting. Pricing CBD long-stay parking at a midway figure of $\$ 6.00$ a day would approximately double the cost of a single occupancy commute trip. It is therefore clear, that free parking induces additional car travel.

The degree to which price would reduce demand for parking is complex and would depend on other variables such as available transport alternatives and the wider parking supply. To investigate how this might play out in Porirua a stated preference survey was distributed to commuters who currently park in the CBD. 


\subsection{Stated choice survey}

Commuters were targeted for the following reasons:

- Single occupancy commute vehicles congest the strategic network and use the roading resource inefficiently

- They are more likely to have other transport options and be prepared to consider using those options

- The literature provides comparative data for this group.

The three factors influencing parking demand that are explored in this survey (price, walking distance and transport alternatives) are well documented in the literature (Hensher \& King, 2001; Marsden, 2006; Shoup, 2005). Parking prices suggested to respondents were based on values from the surrounding region, along with the cost recovery model established above. Commuters have been shown to trade-off long walk times for a free park (Marsden, 2006). To account for parking relocation effects participants were offered the choice of free parking outside the CBD in exchange for a range of walk times. Respondents were provided with a map that graphically displayed this provision. Lastly, participants could choose to change their mode of travel. Porirua is reasonably well supplied with public transport, being situated on a train line and having regular bus services. It is also accessible by cycle from a number of suburbs.

Of the 650 questionnaires distributed, 133 were returned giving a return rate of $20 \%$. Two were not usable. The survey design and model estimation are described in the methodology section. Survey data was processed with Nlogit ${ }^{\mathrm{TM}}$ software. This was carried out by a $\mathrm{PhD}$ student specialising in stated choice techniques. I did not have the necessary background in this field or the knowledge of data entry syntax. The model produced a very high 'puesdo' $\mathrm{R}^{2}$ value of 0.64 . Broadly, this correlates to an $\mathrm{R}^{2}$ value in linear regression analysis ${ }^{13}$ of close to 1 , and is indicative of this model having a very 'good fit' and strong predictive ability (Hensher, et al., 2005).

There are a number of possible reasons for this. Firstly, price and walk time would appear to be the primary influences on commuter demand for parking in Porirua. Secondly, the sample group were, on the whole, respondents who currently commute and park in the CBD and so

\footnotetext{
${ }^{13}$ Sections 4.2 and 6.4 describe linear regression and how to interpret $\mathrm{R}^{2}$ values.
} 
their travel decisions are strongly influenced by any change to the current arrangements. A broader sample of travellers to Porirua would have resulted in a lower pseudo $\mathrm{R}^{2}$ value, as a wider range of influences would have been brought to bear on travel decision making.

The survey included a number of supplementary questions, such as respondent's suburb of residence and perception of available transport alternatives. These can be viewed in Appendix 1. Although the primary focus was on the influence of parking price and walk time, the answers to supplementary questions about the respondent's personal circumstances (covariates) were included in the model and improved the model's overall performance. The parameters relating to each of the covariates are listed in Appendix 2. Price and walk time had statistically significant parameter values but most of the covariates did not.

Covariates were effects coded in the model design and so their influence on choice decisions is not linear but relative to the covariate option that has been excluded. For instance, the influence of where respondents reside on the choice to 'park in the CBD and pay a parking price', is relative to what commuters from the northern suburbs do. One of the covariate parameters relating to public transport options had statistically significant parameter values at the $95 \%$ confidence interval, and so are worth considering briefly. The supplementary question explored respondent's perception of their public transport options. Respondents could answer either, 'Yes' (I have public transport options), 'Yes but inconvenient' or 'No'. The parameter values generated, suggested that those who replied 'Yes' were more sensitive to parking prices and walk times relative to those who answered 'No'. This is intuitive as those with fewer (real or perceived) transport options will be less averse to paying a price for parking than those who can leave the car at home. The same applies for longer walk times.

Table 6 on the following page shows the direct elasticity values of the main effects, price and walk time. As MNL models are non-linear these figures are 'probability weighted sample enumerated elasticities' (Louviere, Hensher, \& Swait, 2000). Elasticity, in this case, is the degree to which a percentage change in price or walk time results in a percentage change in quantity of parking demanded. 
Table 6: Elasticity values

\begin{tabular}{|l|c|c|}
\hline Direct elasticity effect & Mean & Standard deviation \\
\hline Price & -0.5721 & 0.8171 \\
\hline Walk time & -0.9472 & 0.6976 \\
\hline
\end{tabular}

Source: own data

Demand for long-stay parking is weakly elastic with respect to price. The value of -0.6 indicates that if the price of parking increases by $10 \%$, then the demand for parking would drop by $6 \%$. This value compares well with the literature, which gives figures in the range of - 0.3 to - 0.9 (Booz Allen Hamilton, 2006; Marsden, 2006). Commuters in Porirua do not currently face a parking price, meaning that 'a priori' they are possibly more price sensitive. The value might be slightly higher than it otherwise would be if parking was currently priced.

As walk time increases demand for parking also falls. Interestingly, commuters are more sensitive to walking distance (-0.9) than price, suggesting they would be more willing to pay than walk. This is a poorly understood aspect of travel behaviour with the little evidence available showing contradictory results (Marsden, 2006). While it suggests that the impact of spill-over parking might be less than anticipated, this would need to be treated cautiously.

Table 8 shows the percentage of commuters who stated they would choose to pay, walk or change mode in response to rising parking prices and longer walk times. As an example, if commuters were charged $\$ 3$ to park in the CBD $47 \%$ would pay for parking rather than walk 10 minutes, $34 \%$ would park for free in the 10 minute walk zone and $20 \%$ would change mode.

Table 7: Commuter response to parking price and walk time

\begin{tabular}{|l|c|c|c|c|c|c|}
\hline PARKING PRICE & \multicolumn{3}{|c|}{$\$ \mathbf{3}$} & \multicolumn{3}{|c|}{$\$ \mathbf{6}$} \\
\hline WALK TIME (minutes) & $\mathbf{5}$ & $\mathbf{1 0}$ & $\mathbf{1 5}$ & $\mathbf{5}$ & $\mathbf{1 0}$ & $\mathbf{1 5}$ \\
\hline $\begin{array}{l}\text { Park in the CBD and pay } \\
\text { parking price }\end{array}$ & $23 \%$ & $47 \%$ & $57 \%$ & $6 \%$ & $13 \%$ & $17 \%$ \\
\hline $\begin{array}{l}\text { Park outside the CBD and } \\
\text { walk }\end{array}$ & $71 \%$ & $34 \%$ & $16 \%$ & $86 \%$ & $51 \%$ & $27 \%$ \\
\hline Change Mode & $6 \%$ & $20 \%$ & $27 \%$ & $8 \%$ & $35 \%$ & $56 \%$ \\
\hline
\end{tabular}

Source: own data 
Table 8 highlights the level of parking displacement that would result from priced parking. The majority of commuters would walk at least 5 minutes to secure a free park outside the CBD. If the parking price was $\$ 6$ most commuters would be willing to walk for ten plus minutes rather than pay for parking. In the absence of other controls priced parking would make available more than half of the current long-stay parking resource for other uses. However, as the results show, this would by and large shift vehicles to other areas.

Figure 9 illustrates the extent of the parking spill-over area. If parking was priced at $\$ 6$, this would have implications for current on-street parking provision in the industrial zone, western residential areas and the large 'park and ride' parking lot on the eastern side of the railway station. Equally possible (but not assessed in this study) would be the internal spill-over within the CBD zone. This could result in higher levels of illegal parking, cars being moved between short stay areas over the day and a greater use of uncontrolled on-site lots.

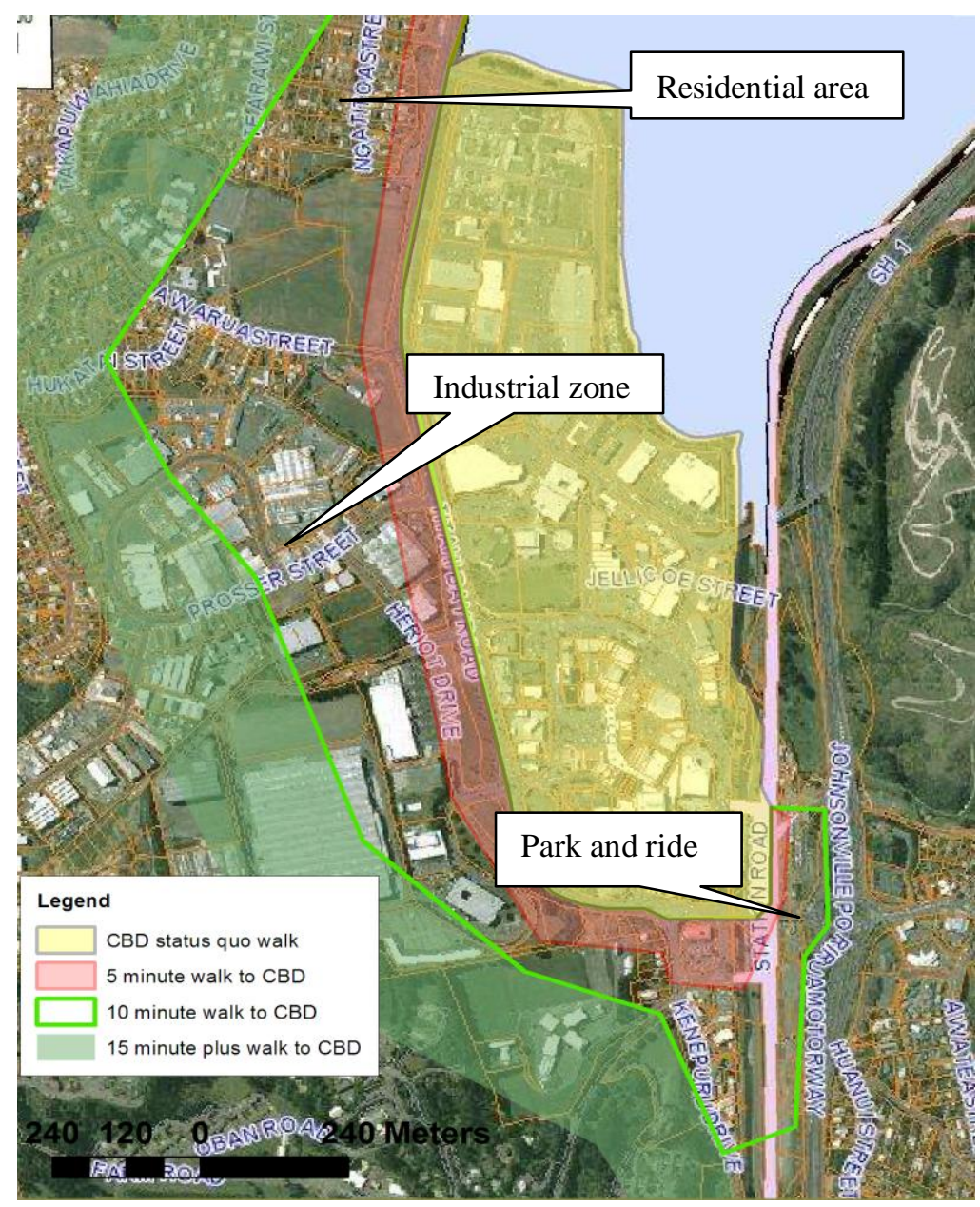

Fig. 9: CBD free parking walking zones

Source: Adapted from GIS maps (http://gis.pcc.govt.nz/pccinvoker/default.aspx) 
Table 8 also indicates that the shift to other modes would be moderate until the walk times and price rose considerably, at which point the shift would be substantial (56\%). Eighty six percent of the survey respondents said that public transport was feasible but almost $60 \%$ of that group felt it was inconvenient. This result might also suggest that convenient free parking has made the trade off in travel time look worse than it otherwise should.

\section{Limitations}

Although the model generated a strong predictive rho squared value the return rate was moderate $(20 \%)$ and the sample size was reasonably small $(n=133)$. This means that the model was not able to make reliable predictions with respect to other variables such as point of trip origin and availability of other transport alternatives. The survey also assumed that people who park in the CBD currently do not incur a walk time, which clearly is not the case. An attitudinal survey conducted by Kelly (2006) found that many employees in the CBD consider the current parking locations and resulting walk times inconvenient.

Income data would have strengthened the findings. Income is likely to affect price sensitivity to parking (A. J. Kelly \& Clinch, 2006). It is unknown whether the sample of respondents is skewed toward a certain income range. Lastly, elasticity values change over time: long-run elasticities in the case of transport are usually higher than short-run ones. In the long-run, consumers would find substitutes to parking such as car pooling and public transport.

\subsection{GIS data: Land use implications}

The analysis so far has focused on the efficiency of parking allocation under the MPRs model and how free parking impacts on transport decisions. This section looks at the impact of parking provision on land use patterns. Parking is land hungry and this is especially true for on-site parking lots. Off-street car parks require more than twice as much land as kerb-side spaces (Cerreno, 2002). While it is true that this need not be the case, structured and underground parking is an order of magnitude more expensive to build and only becomes viable when land prices are very high (Shoup, 2005).

Land use devoted to parking in the CBD was mapped onto an aerial photograph using GIS. The extent of the parking footprint is shown in Figure 10 on the following page. Parking areas are blocked out in red. The bar graph below the legend shows the amount of land devoted to parking by sub-area. Initials denote the three sub-areas. A figure for the VO area, excluding the educational institution, has been included 


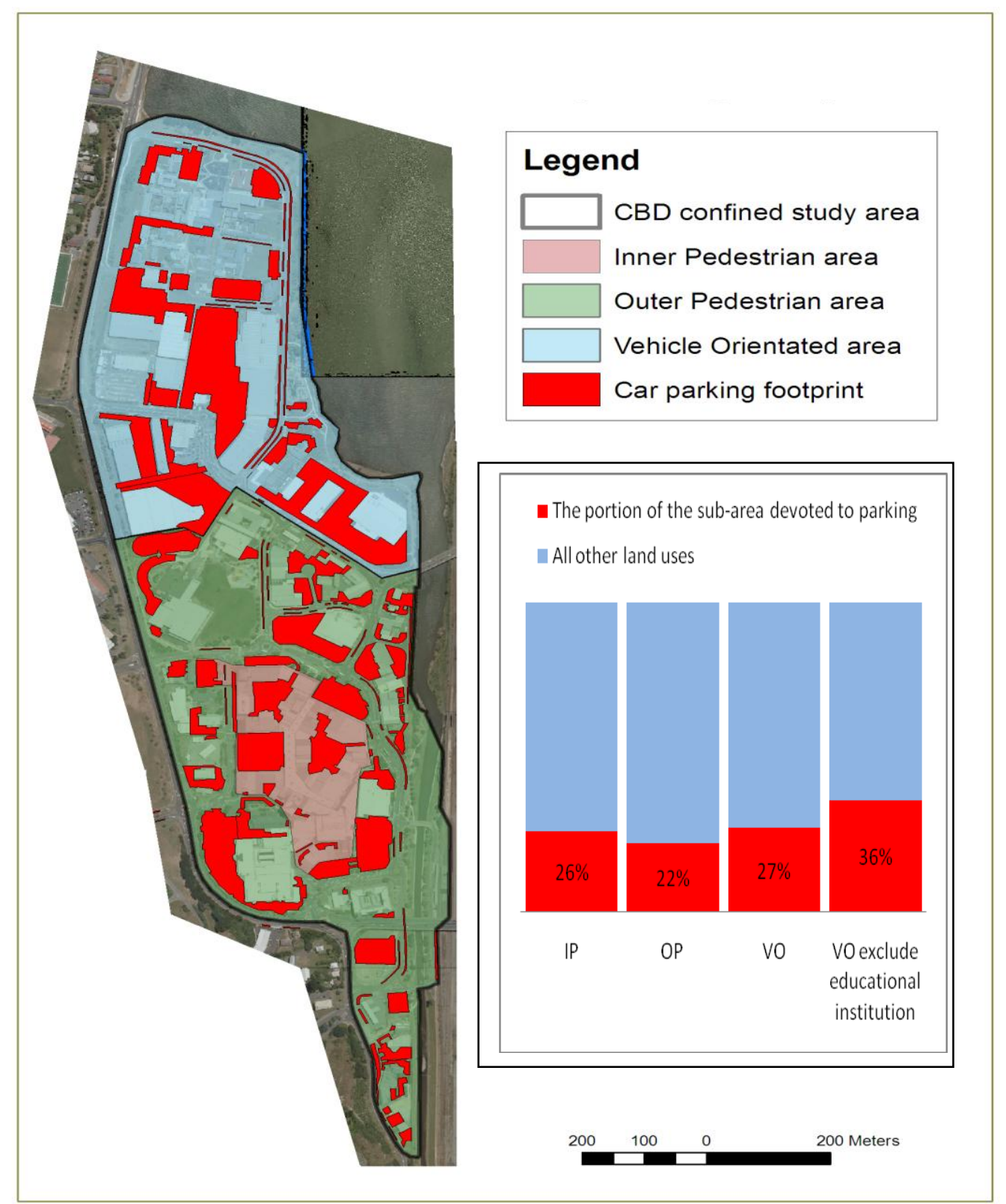

Fig. 10: CBD car parking footprint

Source: adapted from GIS map "Porirua City Centre Public \& Private Car Parking Spaces" (Porirua City Council)

Parking is a major land user throughout the CBD and particularly in the VO sub-area. Ironically, the IP sub-area has a larger proportion of land devoted to parking than in the OP sub-area, despite its pedestrian focus. This reflects the relative preference for vehicle access in the original layout, along with a greater use of off-street parking in this area. Off-street parking, as mentioned earlier, is land hungry. The main areas of CBD green space and open areas are also located in the OP sub-area. The impacts of MPRs start to show up in the VO sub-area where almost $100 \%$ of the parking provision is off-site. If the educational institution at the north end is excluded, $36 \%$ of this area is tied up in parking. 
Figure 11 shows that in total, 24\% of CBD land is allocated to car parking within the natural boundaries of the CBD. Including the wider boundaries of the district plan zone (see Fig. 5), car parking occupies $22 \%$ of the CBD. Values for green/open and recreation space land use categories were provided by Wingya Su (personal commmuciation, September, 21, 2010).

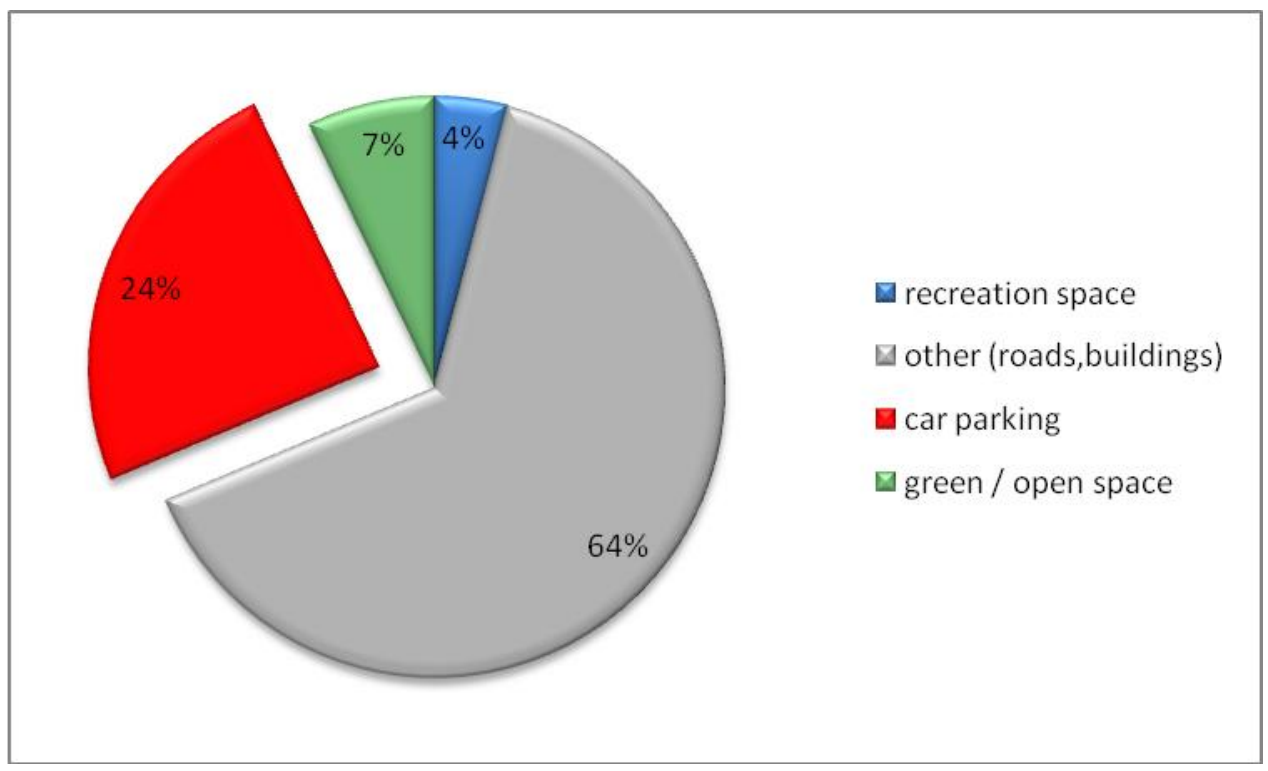

Fig. 11: Area of CBD taken up by various land uses

Source: own data and (Porirua City Council, GIS department)

There is little data to compare this value to. Litman (1997) suggests that a vehicle orientated city uses between 25 to $30 \%$ of its land area in parking and roads. Akbari, et al. (2003) mapped land use in Sacramento city and the wider metropolitan area. They give parking percentages ranging from $10.5 \%$ downtown to between 27 and $56.5 \%$ in commercial shopping areas. Interestingly, a separate report for Sacramento, generated as part of a parking master plan, recognised both the auto-focused nature of development patterns as well as the large amounts of central city parking (around 30\%) unutilised at peak (Loudon \& Halbakken, 2006).

The figures ranging from $26 \%$ in the IP sub-area through to $36 \%$ at the fringe, mean that parking has a dominant impact on the city's urban form and visual amenity. An urban design assessment by the Isthmus Group noted that the city centre was dominated visually and functionally by car parking (cited in T. Kelly \& Incite Ltd, 2006). Further, that vehicle dominance promoted a dispersed city centre, contrary to the district plan intentions of a walkable and consolidated central area. The results of this study support that conclusion. 


\section{Discussion}

The study thus far has outlined how minimum parking requirements have the potential to supply parking above a socially optimal level, resulting in distorted transport and land use decisions. The analysis of empirical results has demonstrated this pattern in Porirua. It might be argued, however, that this is a necessary trade-off to ensure Porirua remains an attractive regional hub. And one of the ways the city has sought to do this is to trade on free and ample parking as a 'point of difference'. Whether free and ample parking actually helps achieve this objective is unknown, but local residents and business appear content with the parking status quo. Ninety two percent of residents said they were very/fairly happy with local parking provision compared to the urban peer group value of 55\% (National Research Bureau Ltd, 2006). Attitudinal surveys indicate that local business believe that plenty of convenient parking is essential for the economic vitality of the city centre (see T. Kelly \& Incite Ltd, 2006).

There is little empirical evidence to support the notion that free and ample parking promotes business vitality (Marsden, 2006; Still \& Simmonds, 2000). It is also intuitive that consumers are drawn to city centres for a variety of reasons. Wellington (and other New Zealand cities) has applied parking restraint and market charging for parking for many years. It continues to have a vibrant inner city despite the subsidised parking approach employed by the competing regional centres of Lower Hutt and Porirua. As Kelly (2006) points out in his parking report, free parking simply presents Porirua as a functional centre rather than a vibrant one.

Parking is a means to an end, not an end in itself and too much parking is as bad as too little (Litman, 2006). Typically, the parking debate fails to specify and measure the trade-offs involved with a subsidised approach versus an approach that seeks to take the wider cost of parking provision into account. The Discussion below presents five arguments that together provide a strong case for taking a different approach than that currently employed. This is followed by a discussion of alternative mechanisms that could be employed to manage parking more efficiently. Lastly, further research opportunities are highlighted along with a reflection on the nature and limitations of this study. 


\subsection{Five reasons for changing parking arrangements in Porirua}

\section{National carbon dioxide emissions}

Porirua, like all New Zealand cities, has a role to play in meeting the Government's goal of a $50 \%$ reduction in carbon emissions (relative to 1990) by 2040. Efficiently allocated and priced parking reduces wasteful driving while encouraging the use of lower emission transport alternatives (Marsden, 2006). National trends in vehicle ownership and fuel prices also suggest that levels of driving, and by default parking demand, will be reduced in future. Vehicle ownership rates plateaued in 2005, and are possibly reaching saturation (Donovan, et al., 2008). The introduction of the New Zealand emissions trading scheme in 2010, along with the likelihood of rising oil prices (Hook, 2009), will increase fuel costs and dampen the demand for driving.

\section{Regional and local travel demand}

Helping to manage travel demand in line with the Regional Land Transport Strategy is a role Porirua City plays within the wider region. The current reliance on generous MPRs appears to limit the council's ability to achieve travel demand objectives in the following ways

Firstly, current parking standards create an oversupply of parking at most sites. This allows commuters 'to hide' on customer lots (and avoid paying for parking), as they have little impact on the levels of available parking. Developers can limit this with appropriate enforcement. The presence of uncontrolled parking lots and parking coupon systems, however, indicates there are incentives to provide employee parking free of charge. As a result, the long-stay parking supply actually outstrips demand in the CBD, even though in the minds of some employees and businesses convenient commuter parking is lacking (see T. Kelly \& Incite Ltd, 2006).

On the Thursday count, this study found empty on-street spaces along with numerous opportunities to park at uncontrolled parking lots. The leased long-stay parking stock (private off-street reserved, Table 2) was also underutilised. While this might reflect an information barrier it also highlights how community expectations match historic provision. Results from the stated preference survey showed that if parking was priced commuters would walk significant distances out of the CBD to secure a free park. 
Secondly, long stay parking on these sites works against the intent of the district plan and resource consent conditions. For instance, a retail development in the VO sub-area agreed to limit long stay parking to 3\% of total supply (11 parks / 427). This study found 60 long-stay parkers at this site on Thursday and 40 on Saturday. That represents $18 \%$ and $12 \%$ of the total supply (now 342) respectively. Clearly any provisions against long-stay parking are not enforced or weakly enforced. On average long-stay parking consumed $12 \%$ of the on-site customer parking resource. Commuter use of these sites is inefficient and subsidises the travel of those who prefer to commute by car to work.

Lastly, long-stay parking across the city is free. While public long-stay parking could be priced the council has no incentive to enforce pricing where there is an oversupply nearby. A previous attempt to do this failed and this was one of the reasons (T. Kelly \& Incite Ltd, 2006). Travel demand management without priced parking has little or no impact (TRCP, 2005). Even if supply restraint is employed, free parking ensures that there is no mechanism to allocate the long-stay resource to the highest value use. A commuter from Elsdon suburb, less than two kilometres from the CBD with a number of transport alternatives, has equal access, at zero price, to the resource as those who may be prepared to pay more for a park. This is clearly inefficient.

MPRs have meant that parking is now largely owned and controlled by dispersed private business owners. The split stands at almost 35:65; public to private sector respectively. This would work if private control led to a market for parking. MPRs, however, ensure this will not be the case. The small percentage remaining in public ownership complicates the future management of the resource, a point raised by Kelly (2006) in his parking report. On the other hand, abolition of MPRs would likely lead, over time, to a reduction in private parking provision and a rebalancing of the total resource.

\section{Opportunity cost to development}

Developers, rather than Porirua City Council bear the initial cost of parking provision. The data analysis shows that, by and large, current provision is oversupplied even at peak. This imposes an opportunity cost on development and the wider city in lost income and business development. It is hard to quantify what this amounts to in the absence of comparative data 
where parking requirements are not imposed on developers. However, a number of indicators point to Porirua City MPRs being a disincentive to current and future development.

Firstly, most developers in the CBD have wanted to supply less parking than the district plan rates. Ninety percent of the private off-site customer parking resource is currently supplied below the district plan minimum standards. Eighteen (80\%) of the 22 developments assessed in this study were below the permitted standard and $11(50 \%)$ were below the discretionary standard. This finding aligns with the literature suggesting that MPRs are largely driven by local authorities (Shoup, 2005). A survey of 300 U.S. developers found that $74 \%$ thought that MPRs were a major cost and barrier to development (Riggs, 2009).

Secondly, while developers can always negotiate the rates down, in discussion with the Council, there are transaction costs associated with this approach, and the Council is not obliged to give discretionary status even with expert evidence. A resource consent lodged so that a large mall could install a car wash highlights these costs. Six car parks were at stake representing a $0.5 \%$ reduction in the total stock. Even though the car wash would likely be used by on-site shoppers (no net loss of parking) expert opinion in the form of a traffic assessment was required (RC5185 Porirua City Council, 1998 - 2006). Such an expert assessment is costly.

Thirdly, land in the CBD is now scarce and increasingly expensive. The provision of large amounts of parking (due to current standards) will be a significant cost going forward. Wellington City (Porirua's closest neighbour) abolished MPRs in 1991. This allows developers to provide the level they deem appropriate. The savings associated with Wellington's approach could impact on Porirua's attractiveness to developers as a development location.

Fourthly, the current approach does not allow an underutilised parking resource to be freed up for alternative uses. Twenty four percent of the CBD is locked-up in parking and some of this land is poorly utilised. The district plan notes that "Commercial developers are well aware of the importance of adequate car parking, and of the need for convenient car parking" (Porirua City Council, 1999 C1.2.2). While developers are well aware and are paying for it, planning officers are setting the minimum rates. The incentive mechanism in this approach is misplaced. 


\section{Incompatible with wider multimodal goals and compact development}

The following quote by Vanderbilt highlights how vehicle travel has displaced other transport modes; "Thus it was quickly established that the prime objective of a street was simply to move as many cars as quickly as possible - an idea that obscured, as it does to this day, the many other roles of city streets" (2008, p. 12).

Porirua has a goal to enhance pedestrian access in the city centre, as the district plan states; "To promote a pedestrian focused environment in the City Centre that provides a high level of visual amenity and pedestrian convenience while minimising the adverse effects of vehicle traffic" (Porirua City Council, 1999 C1.1.2). Cycling is also promoted as a major mode of travel throughout the city in Objective C7.1.7. Porirua City's revitalisation program will seek to enhance and encourage pedestrian movement further.

When active modes are well represented it is generally good for urban vitality (Marsden, 2006) and people's health (Woodward \& Lindsay, 2010). Schemes to promote them often involve a trade-off with car parking, however (Schaller Consulting, 2006; Sztabinski, 2009). Copenhagen has seen a remarkable shift to bicycle commuting (now a 30\% share). This occurred concurrent with the removal of 2500 car parks over ten years along with the installation of cycle ways (Beatley, et al., 2009).

Nelson City, which is a similar size to Porirua, is also pursuing a revitalisation program to enhance its inner city area (2009). To achieve this, the following parking measures are being applied: abolish MPRs in the CBD, change angle parking to parallel in strategic areas (effectively reducing the parking stock) and price short-stay parking. In the longer term, longstay parking will also be priced.

Porirua's MPRs and general approach to free and ample provision is at odds with its multimodal goals. Further parking provision in the IP sub-area (currently required under the district plan) will increase kerb cuts and traffic movements while reducing the pedestrian amenity. Abundant parking has also stifled pedestrian movement in the VO sub-area. A 2002 traffic report on the large scale retail development in this sub-area showed little pedestrian movement across the dividing road (RC1710 Porirua City Council, 1998 - 2006). 
Cycling is also unconsciously discouraged. Parking provision at developments is mandatory, while cycle infrastructure is merely 'encouraged'. Not surprisingly, cycle infrastructure and dedicated access ways are few and far between. Employees at a number of these sites are able to park for free, but it is unlikely that cyclists have safe lockable areas and access to a shower. This constitutes a bias in the system. The district plan laments the lack of cyclists yet ensures this situation continues by making car use cheap and easy relative to other modes. Greater use of the current bus service would also result from a removal of free parking subsidies. The survey reported earlier, suggests that up to $56 \%$ of respondents would switch to other modes if parking was priced and the potential for parking displacement managed. For a multimodal community to arise, consumers need viable options and the current approach to parking provision is a disincentive to this.

\section{Visual impacts}

"The more parking, the less place. The more place, the less parking" (Jane Holtz Kay cited in Shoup, 2005, p. 162). Surface parking is aesthetically ugly and MPRs ensure they are visually dominant. In two out of three sub-areas parking makes up more than one quarter of the landuse total. Developments in the VO sub-area have up to $60 \%$ of their total site area committed to car parking. This level of dominance is a huge impediment to achieving visually appealing and integrated urban design, especially as parking is purely functional and therefore little or no money is invested in it to make it visually attractive.

A common concern raised during the consent process for the retail development mentioned earlier was its potential lack of integration with the harbour (RC1710 Porirua City Council, 1998 - 2006). The stream and harbour are natural assets that enhance the city and the wider locale. Unfortunately, the concerns around integration were not addressed. The current arrangement has shops facing inward toward the car park with harbour views and access blocked by a six metre high continuous wall. The permissive approach of the district plan in regard to design criteria is also to blame. It is a challenging task for any development design to maintain integration and visual amenity while managing a car parking footprint that covers up to $60 \%$ of the site area. Current standards for the wider VO sub-area are 5 parks per $100 \mathrm{~m}^{2}$ of GFA. This ensures that car parking will be the dominant land use along most of the of the harbour edge. It will also stifle attempts to effectively integrate visual and pedestrian access to 
this area. And what is likely to be lost on the many drivers who will enjoy this free and ample parking is the implicit trade-off that has occurred.

A council owned development directly across the road in the OP sub-area highlights the tradeoff involved with parking provision. The recreation centre / library complex, by virtue of its 'designation status', was not obliged to adhere to district plan standards. Parking at these sites is less than half the permitted rates. Partly as a result they are pedestrian friendly and include large open areas with high levels of visual amenity. If parking had been supplied to the permitted standard a substantial portion of this area would have been lost to parking including the very popular skate park.

The following section sets out a range of alternative approaches that would supply parking more efficiently and, to some degree, mitigate the impacts now seen on land use and transport patterns.

\subsection{Alternative approaches}

"Well designed parking policies, in various ways, contribute to the promotion of a more efficient use of the transport network, lower emissions, higher densities and better, more inclusive urban design" (Marsden, 2006, p. 450) .

The current parking standards in Porirua are inflexible and provide council and developers little opportunity to respond to the many factors that influence parking demand, while also accommodating wider city goals and objectives. A historic focus on parking 'capacity' rather than 'management' has resulted in inefficient use of the parking resource and associated land. The district plan argues that this approach is sustainable management of the parking resource (Porirua City Council, 1999). However, oversupplied and underutilised parking with its attendant stormwater runoff and transport implications can hardly be classed under this heading. Alternative approaches can allocate parking more efficiently. What is critical, however, is that a city-wide parking strategy is in place to ensure that any interventions implemented are effective and that perverse outcomes, such as parking spill-over, can be managed (Auckland Regional Transport and Urban Development Committee, 2009). The results from the stated choice survey highlighted how a parking strategy in the CBD (pricing) has implications for the wider city area. 
Parking provision is not an exact science (Litman, 2006). However, Litman argues that with a flexible approach, that includes contingency planning, a much lower baseline of parking provision can be started from than traditional MPRs provide. This is particularly true if alternative transport options are good (Marsden, 2006). A thorough analysis of the pros and cons of various strategies are laid out in Litman's (2006) book Parking Management Best Practices along with a set of ten principles that should guide the development and application of parking strategies. Attention to alternative parking allocation mechanisms is also provided in Shoup's (2005) book The High Cost of Free Parking. What follows is a brief overview of practices that are, in my opinion, applicable to Porirua.

\section{Abolish minimums}

Shoup (2005) argues strongly for parking to be left to the market as Wellington has done. The recently completed Auckland Regional Parking Strategy (2009) also recommends the removal of MPRs from urban centres. Kelly's report (2006) argues that removal of MPRs in the Porirua CBD is not warranted based on an analysis of non-complying resource consents. This present study finds the opposite. Most of the parking resource is currently supplied below the required rate indicating that developers are looking to reduce the supply rate. A further argument for this approach is to retain competitiveness with Wellington and use currently underutilised parking lots more efficiently. If the council is looking to free up land for development this approach is politically palatable compared to the public discussion that would likely result from diverting the current public stock for alternative uses (Rye, et al., 2009). Abolishing minimums has the disadvantage of providing no revenue, which a fee in lieu does.

\section{Fee in lieu}

Some cities allow a fee paid in lieu of parking provision. A set fee, based on the cost of providing a structured car park, is paid to the council who have obligations to provide the resource within an agreed timeframe. When set up appropriately, fee in lieu payments can foster infill development and efficient parking management (Gray, 2004). The resulting shared parking also reduces the total parking needs relative to on-site provision while also using land more efficiently (Litman, 2006).

Limitations of this approach centre around the underlying parking requirements driving the supply rate and the manner and level of the required payments. These factors can severely 
impact on the schemes' uptake (Gray, 2004) and efficiency of parking provision (Shoup, 2005). A fee in lieu charge could provide the council with the necessary funds to erect a parking building in the CBD.

\section{Kerb-side parking}

A greater provision of kerb-side parking could offset reductions in MPRs while also freeing up CBD land. Kerb-side parking is currently a small component of the total supply. As pointed out in the data analysis, kerb-side provision uses land more than twice as efficiently while also having higher mean utilisation rates, being a shared resource. There is also evidence that it does not congest traffic to the level claimed and that this is primarily the effect of intersections (Litman, 2006). A comprehensive review of kerb-side parking by Cerreno (2002) suggests the advantages greatly outweigh the disadvantages. A greater use of kerb-side parking in Porirua, particularly in the VO sub-area, could reduce kerb cuts, increase council ownership of the total parking resource and reduce on-site provision.

\section{Price parking}

Pricing can achieve a number of objectives. Pricing long-stay parking will ensure the resource is allocated to its highest value use, help achieve travel demand objectives and promote the use of alternate modes. As the stated preference survey demonstrated, pricing will require a city-wide parking policy to manage parking spill-over. Current demand at the short stay public stock indicates that pricing would be appropriate here as well. A number of the OP sub-area short stay lots reach capacity at multiple times during the week. The manner in which council targets are set for this resource tends to hide the high levels of usage that various lots receive. Targets are based on the average 6 day peak occupancy rates across the whole resource. Priced parking would encourage efficient driving, longer stays in the CBD (a common response to price) and ensure that parking availability was managed so that some parks (commonly 15\%) are always empty (Shoup, 2005). It was apparent in the occupancy study that a number of long-stay cars were moving around the city centre short-stay parking areas. Pricing would discourage this. A return on the investment would also encourage the council to take a more robust approach to enforcement. Current enforcement is limited, paid out of general rates and requires the parking warden (in the time limited areas) to pass a given car twice to check it is complying with the time limit. A priced system is self funding and requires just one pass by the warden to check a car's compliance. 
The public and business may resist this change of approach, so altering the parking regime would need to be combined with a city-wide parking policy, a rationale for the trade-offs and various information campaigns. Clear and well presented parking information is critical, as is the need to address perceptions of parking restraint. Rye, et al. (2009) showed that despite the public's view to the contrary there was spare capacity across Edinburgh during peak period. In the long term a well managed and priced resource is usually appreciated (EPA, 2006; Shoup, 2005). Kelly (2006) argues that pricing the time limited public stock is not feasible because of the resulting spill-over onto surrounding development sites. This is a fair point given the relative split between public and private ownership in Porirua. However, it is equally clear that many cities from the small (Levin) to the large (Lower Hutt) manage this problem while supporting their inner city area.

\section{Better match supply and demand}

If MPRs are to be retained a range of approaches can be taken to ensure a better match between demand and supply. The exclusive reliance on GFA as a demand predictor was shown in the data analysis to provide a poor match. This approach is also atypical, with most cities specifying minimums based on activity types. Although specific activity rates provide a closer fit, they rest on the same assumptions that inform the current GFA based rates. Litman (2006) suggests supplementing the standard predictive variables with a range of further factors to reflect the various socio-demographic features of the local region. These factors range from residential density, transit accessibility, land use mix to employment density. CBD rates could also be reduced for sites that provide cycle parks and/or evidence of a travel demand plan.

A particular concern for the district plan is the long term use of the site. The plan notes that it is difficult to retrofit parking. A flexible approach that provides for contingency planning, along with management techniques such as pricing, go a long way to managing this concern. Increasingly, developers are unbundling parking from residential developments in inner city locations. The attractiveness of a given CBD development to potential businesses is likely to be less tied to parking provision than in the past.

These interventions represent just a sample of the many innovative ways that local authorities can effect change to parking management. 


\subsection{Research limitations and contributions}

Minimum parking requirements, although widely used, have been the subject of ongoing criticism internationally (Shoup, 2005; Willson, 1995). This research adopted an environmental-economic framework to investigate the use of MPRs in the context of a small New Zealand city. In line with international work, the wider impacts of MPRs on land use and transport patterns were assessed. The research findings are broadly in line with work from the U.S. and Canada (Litman, 2006; Shoup, 2005). This would indicate that MPRs (at least in the case of Porirua) have been applied in much the same manner and have resulted in many of the same outcomes as international experience.

While economic theory provides a rationale for efficient allocation there are limitations with this approach. There is a wider political and financial context that bears on parking provision at the local level that this study did not investigate. Local councils (particularly small ones) have limited resources. As Willson (1995) notes, MPRs are 'administratively simple' and mean that local authorities are not burdened with the cost of parking provision. MPRs have also been part of the planning landscape for a long time and bureaucratic change, as Lindblom (1979) notes, is slow. Political barriers and institutional arrangements also bear on this process (Preval, Hulme-Moir, \& Fougere, 2010).

The role of institutional arrangements and wider socio-political considerations in informing and giving rise to the current approach to parking could have been investigated though interviews with council officers, city councillors and local business. Developers are also actors in this process, as they ultimately bear the cost of MPRs. Interviews with developers could shed light on how MPRs impact on their locational decisions, transaction costs and development choices. A further insight could be given into how regulation creates a 'development path' that is challenging to change in the short term. This relates to the need of developers to remain competitive by providing at least as much parking as the competition.

A limitation of the case study approach employed in this research is a lack of comparative data meaning research findings have a limited scope for generalising (Willson, 1995). There are numerous future research opportunities in this area. Some of these are listed below:

- Compare parking provision at sites with no minimum rates to comparable sites under MPRs 
- Investigate parking density in a range of New Zealand cities and compare these with parking requirements in the district plan

- Investigate and value the lost opportunity cost to development associated with MPRs

- Investigate why some local authorities have moved away from MPRs toward other mechanisms such as maximums, and how, and if this contributes to the sustainability of inner city areas.

This research has contributed to a poorly understood area of transport provision and engages a wider debate about how MPRs are determined, how they are used and whether they are an appropriate mechanism to achieve efficient and sustainable use of land and transport resources. The research provides empirical data for making 'evidence based decisions' about parking policy at the Porirua level and provides insight into how priced commuter parking has wider ramifications than is immediately apparent. 


\section{Concluding remarks}

MPRs, while an easy 'answer' to the issue of parking management, are part of a transport paradigm that has largely focused on providing for car accessibility and ease of traffic movement with little thought to wider impacts. The sheer financial burden of this approach to transport, along with the attendant health and environmental outcomes, is neither sustainable nor beneficial in the long term (Banister, 2000). The need to develop sustainably and to use valuable resources more efficiently have become increasingly important concerns worldwide. And the urban environment will be one area where addressing these concerns' will be played out. The majority of the world's population live in cities and this trend will continue in the future, ensuring that the sustainable development of cities is an important issue. City-form that is sustainable and resilient will result, amongst other things, in less driving, better health outcomes and more efficient use of land.

There are numerous ways being suggested to reorientate the current patterns of urban transport and development. Parking policy is one of the levers available to planners and policy makers that has often been overlooked. And in this regard, reforming MPRs has been described as a 'low hanging fruit' amongst a raft of available options. It warrants this description as MPRs intersect the land use and transport fields and offer a low cost, politically palatable and effective mechanism for lowering parking densities and encouraging cities to be areas of compact development and high population density. This in turn is known to reduce VKT and car ownership in the long run (Ewing, et al., 2007). This research has highlighted how MPRs in Porirua tend to oversupply parking and reinforce a pattern of free and ample provision. Reforming the way that MPRs are prescribed at the local level, while providing appropriate price signals to car drivers, has the potential to move the city toward a more compact form with a greater use of alternative modes. This in turn will support the goal of a vibrant city centre. 
Appendix 1: Stated choice questionnaire

\section{PARKING QUESTIONNAIRE}

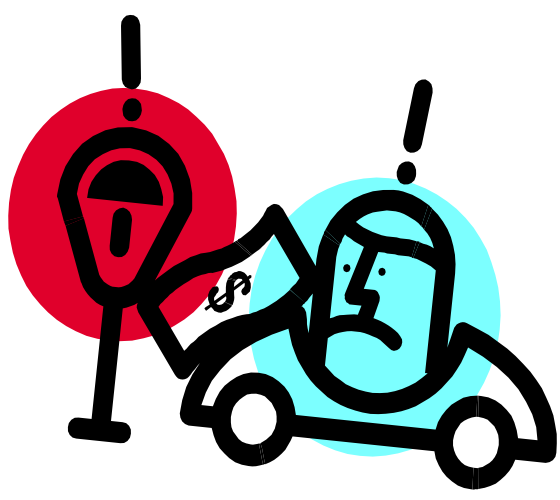

\section{How would you respond if you had to pay for parking in the city centre?}

Hi.

Thank you for taking the time to read this. I am a student at Victoria University and am interested in how people travel to work and what factors influence that decision. Would a price on parking influence your decision? What about other options such as the bus? I am interested in your views on these matters and would greatly appreciate your input.

- The questionnaire takes on average 5-10 minutes to complete

- The questionnaire will be treated confidentially

- It is not connected to Porirua City Council

As a way of showing my appreciation for your time there are TWO, \$100 NORTH CITY PLAZA VOUCHERS to be won.

Send in your completed questionnaire and go in the draw to win.

- This questionnaire is part of a research project towards a masters degree in Environmental Studies at Victoria University. The results (which are part of a wider study into parking and transport) will be published at the university and/or in an academic journal

- The questionnaire will be treated confidentially. Only myself and my supervisor will have access to the data and the questionnaires will be destroyed at the conclusion of the research

- The data will be published anonymously. You will not be able to be identified from your responses

- Addresses are collected for the purpose of mailing out prizes and results.

- If you agree to these conditions please tick the consent box at the end of the questionnaire

If you have any concerns about the nature of the study or the questions asked, please contact either myself or my supervisor.

Supervisor

Ralph Chapman

Associate Professor

School of Geography and Earth Sciences

Ph: 4636153

\section{Student}

Angus Hulme-Moir

Victoria University of Wellington

Ph: 4635233 extn 8347 
In Porirua City Centre parking is free

However, if you did have to pay for parking would this influence the way that you currently travel to work?

This questionnaire presents you with scenarios but only gives you three options to choose between. They are:

OPTION 1: Park in the city centre and pay a parking fee

OPTION 2: Park for free outside the city centre and walk in (see the map below)

OPTION 3: Change the way you travel to work (e.g. use public transport, cycle or walk) The map highlights areas outside the city centre where you might park for free and walk in.

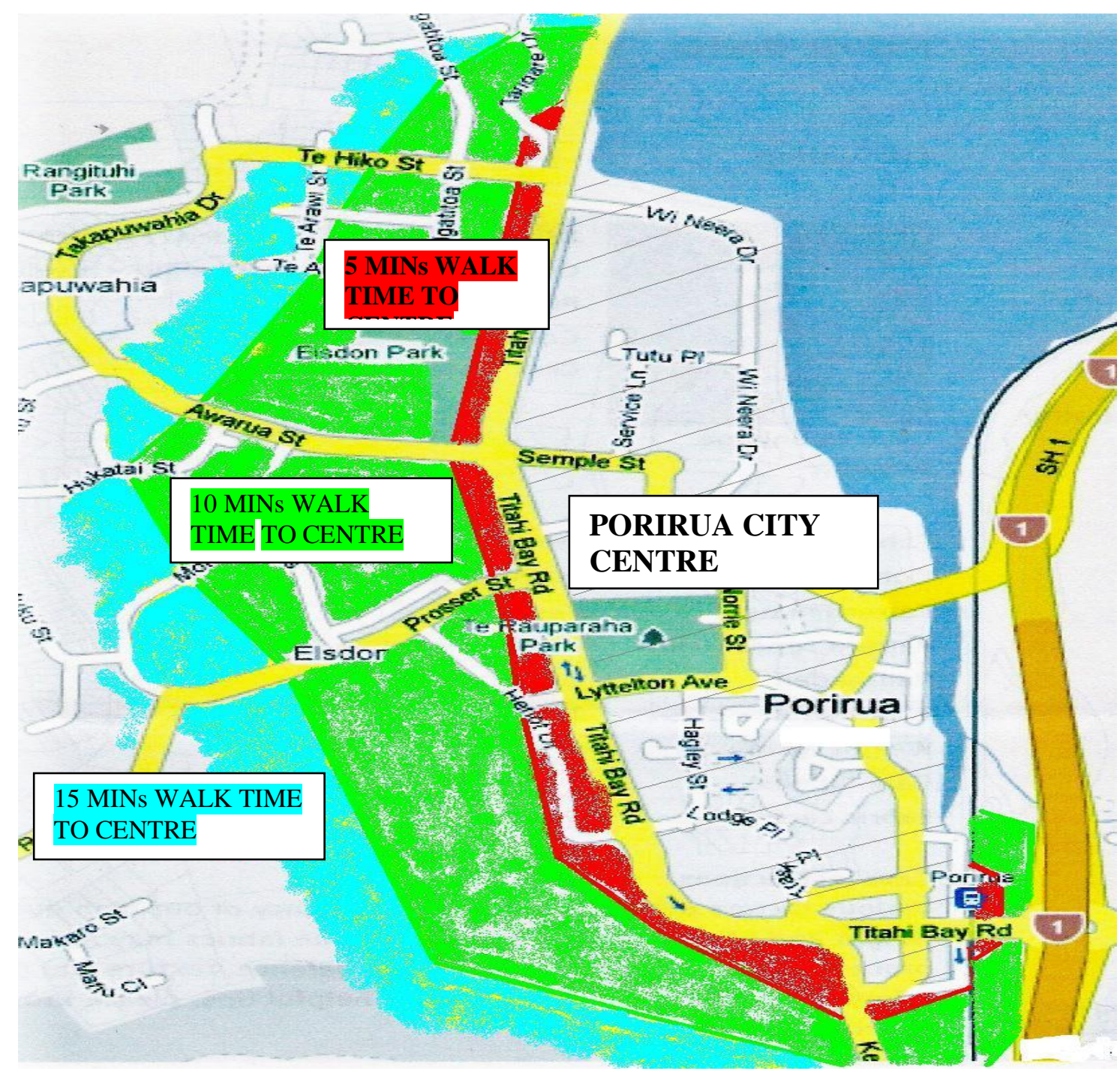

- The red area includes parking by Bunnings and close to the train station

- The green area includes Kenepuru road, lower Prosser St and the wider rail station park

- The blue area includes Upper Prosser St and the hospital 
Remember EACH SCENARIO HAS A DIFFERENT COMBINATION of parking price and walking time

\section{SCENARIO A}

Tick the box of the option that you would choose

\begin{tabular}{|l|l|l|}
\hline \multicolumn{1}{|c|}{ OPTION 1 } & \multicolumn{1}{|c|}{ OPTION 2 } & \multicolumn{1}{c|}{ OPTION 3 } \\
Park your car in the city centre & $\begin{array}{l}\text { Park your car for free outside the } \\
\text { city centre and walk in } \\
\text { Walk time: 5 mins each way } \\
\text { Price: \$3 all day }\end{array}$ & $\begin{array}{l}\text { Travel to work some other way } \\
\text { (e.g. bus, walk, train or share a } \\
\text { car ride) } \\
\text { OPTION 2 }\end{array}$ \\
OPTION $1 \quad \square$ & \\
\hline
\end{tabular}

SCENARIO B

Tick the box of the option that you would choose

\begin{tabular}{|l|l|l|}
\hline \multicolumn{1}{|c|}{ OPTION 1 } & \multicolumn{1}{|c|}{ OPTION 2 } & \multicolumn{1}{c|}{ OPTION 3 } \\
Park your car in the city centre & $\begin{array}{l}\text { Park your car for free outside the } \\
\text { city centre and walk in } \\
\text { Walk time: 5 mins each way } \\
\text { Price: } \$ 6 \text { all day }\end{array}$ & $\begin{array}{l}\text { Travel to work some other way } \\
\text { (e.g. bus, walk, train or share a } \\
\text { car ride) } \\
\text { OPTION 2 }\end{array}$ \\
OPTION 1 $\square$ & \\
\hline
\end{tabular}

SCENARIO C

Tick the box of the option that you would choose

\begin{tabular}{|l|l|l|}
\hline \multicolumn{1}{|c|}{ OPTION 1 } & \multicolumn{1}{|c|}{ OPTION 2 } & \multicolumn{1}{c|}{ OPTION 3 } \\
Park your car in the city centre & $\begin{array}{l}\text { Park your car for free outside the } \\
\text { city centre and walk in } \\
\text { Walk time: 15 mins each way } \\
\text { Price: \$3 all day }\end{array}$ & $\begin{array}{l}\text { Travel to work some other way } \\
\text { (e.g. bus, walk, train or share a } \\
\text { car ride) } \\
\text { OPTION 2 }\end{array}$ \\
OPTION 1 $\square$ & \\
\hline
\end{tabular}

SCENARIO D

Tick the box of the option that you would choose

\begin{tabular}{|l|l|l|}
\hline \multicolumn{1}{|c|}{ OPTION 1 } & \multicolumn{1}{|c|}{ OPTION 2 } & \multicolumn{1}{c|}{ OPTION 3 } \\
Park your car in the city centre & $\begin{array}{l}\text { Park your car for free outside the } \\
\text { city centre and walk in } \\
\text { Walk time: 15 mins each way } \\
\text { Price: free all day }\end{array}$ & $\begin{array}{l}\text { Travel to work some other way } \\
\text { (e.g. bus, walk, train or share a } \\
\text { car ride) } \\
\text { OPTION 2 }\end{array}$ \\
OPTION 1 $\square$ & & \\
\hline
\end{tabular}


SCENARIO E

Tick the box of the option that you would choose

\begin{tabular}{|l|l|l|}
\hline \multicolumn{1}{|c|}{ OPTION 1 } & \multicolumn{1}{|c|}{ OPTION 2 } & \multicolumn{1}{c|}{ OPTION 3 } \\
Park your car in the city centre & $\begin{array}{l}\text { Park your car for free outside the } \\
\text { city centre and walk in } \\
\text { Walk time: 15 mins each way } \\
\text { Price: } \$ \mathbf{6} \text { all day }\end{array}$ & $\begin{array}{l}\text { Travel to work some other way } \\
\text { (e.g. bus, walk, train or share a } \\
\text { car ride) } \\
\text { OPTION 2 }\end{array}$ \\
OPTION 1 & $\square$ & \\
\hline
\end{tabular}

SCENARIO F

Tick the box of the option that you would choose

\begin{tabular}{|l|l|l|}
\hline \multicolumn{1}{|c|}{ OPTION 1 } & \multicolumn{1}{|c|}{ OPTION 2 } & \multicolumn{1}{c|}{ OPTION 3 } \\
Park your car in the city centre & $\begin{array}{l}\text { Park your car for free outside the } \\
\text { city centre and walk in } \\
\text { Walk time: 10 mins each way } \\
\text { Price: free all day }\end{array}$ & $\begin{array}{l}\text { Travel to work some other way } \\
\text { (e.g. bus, walk, train or share a } \\
\text { car ride) } \\
\text { OPTION 2 }\end{array}$ \\
OPTION 1 $\square$ & \\
\hline
\end{tabular}

\section{SCENARIO G}

Tick the box of the option that you would choose

\begin{tabular}{|l|l|l|}
\hline \multicolumn{1}{|c|}{ OPTION 1 } & \multicolumn{1}{|c|}{ OPTION 2 } & \multicolumn{1}{c|}{ OPTION 3 } \\
Park your car in the city centre & $\begin{array}{l}\text { Park your car for free outside the } \\
\text { city centre and walk in } \\
\text { Walk time: 10 mins each way } \\
\text { Price: \$3 all day }\end{array}$ & $\begin{array}{l}\text { Travel to work some other way } \\
\text { (e.g. bus, walk, train or share a } \\
\text { car ride) } \\
\text { OPTION 2 }\end{array}$ \\
OPTION 1 $\square$ & OPTION 3 \\
\hline
\end{tabular}

SCENARIO $\mathrm{H}$

Tick the box of the option that you would choose

\begin{tabular}{|l|l|l|}
\hline \multicolumn{1}{|c|}{ OPTION 1 } & \multicolumn{1}{|c|}{ OPTION 2 } & \multicolumn{1}{c|}{ OPTION 3 } \\
Park your car in the city centre & $\begin{array}{l}\text { Park your car for free outside the } \\
\text { city centre and walk in } \\
\text { Walk time: 5 mins each way } \\
\text { Price: free all day }\end{array}$ & $\begin{array}{l}\text { Travel to work some other way } \\
\text { (e.g. bus, walk, train or share a } \\
\text { car ride) } \\
\text { OPTION 2 }\end{array}$ \\
OPTION 1 $\square$ & OPTION 3 \\
\hline
\end{tabular}


SCENARIO I

Tick the box of the option that you would choose

\begin{tabular}{|l|l|l|}
\hline \multicolumn{1}{|c|}{ OPTION 1 } & \multicolumn{1}{|c|}{ OPTION 2 } & \multicolumn{1}{c|}{ OPTION 3 } \\
Park your car in the city centre & $\begin{array}{l}\text { Park your car for free outside the } \\
\text { city centre and walk in } \\
\text { Walk time: } \mathbf{1 0} \text { mins each way } \$ \mathbf{6} \text { all day }\end{array}$ & $\begin{array}{l}\text { Travel to work some other way } \\
\text { (e.g. bus, walk, train or share a } \\
\text { car ride) }\end{array}$ \\
OPTION 1 & $\square$ & OPTION 3 \\
\hline
\end{tabular}

1. What suburb do you commute from

Northern Porirua Suburbs

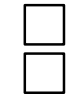

Eastern Porirua Suburbs

Western Porirua Suburbs

Other:

2. Do you have other options to driving your car, such as public transport, cycling or walking

$$
\text { No } \square \quad \text { Yes (but inconvenient) } \square \quad \text { Yes }
$$

3. From the list below choose the $\mathbf{3}$ most important factors in your decision to drive. Rank them from 1 (most important) to 3 (least important)

$\begin{aligned} & \text { Distance } \quad \text { Free parking } \\ & \text { nearest } \\ & \text { public transport }\end{aligned}$
Convenience $\quad \begin{gathered}\text { Cost of public transport } \\ \text { I need my car for work }\end{gathered} \quad \begin{aligned} & \text { Linking trips such } \\ & \text { as picking up } \\ & \text { children } \\ & \text { /shopping etc }\end{aligned}$

\section{CONSENT:}

I need your consent to use this data. See the information box on the front page if you are unsure.

I understand how this questionnaire will be used and consent to this:

If you would like me to post the results to you please tick this box

\section{PRIZES}

If you would like to enter the draw for the vouchers please fill in your details below.

NAME:

ADDRESS:

\section{LASTLY}

Fold the questionnaire in three. Make sure the FREEPOST address is visible on the back. The prizes will be drawn on November the $12^{\text {th }}$. Send you questionnaire in before this date 
Appendix 2: Variable coefficients estimated using stated choice data

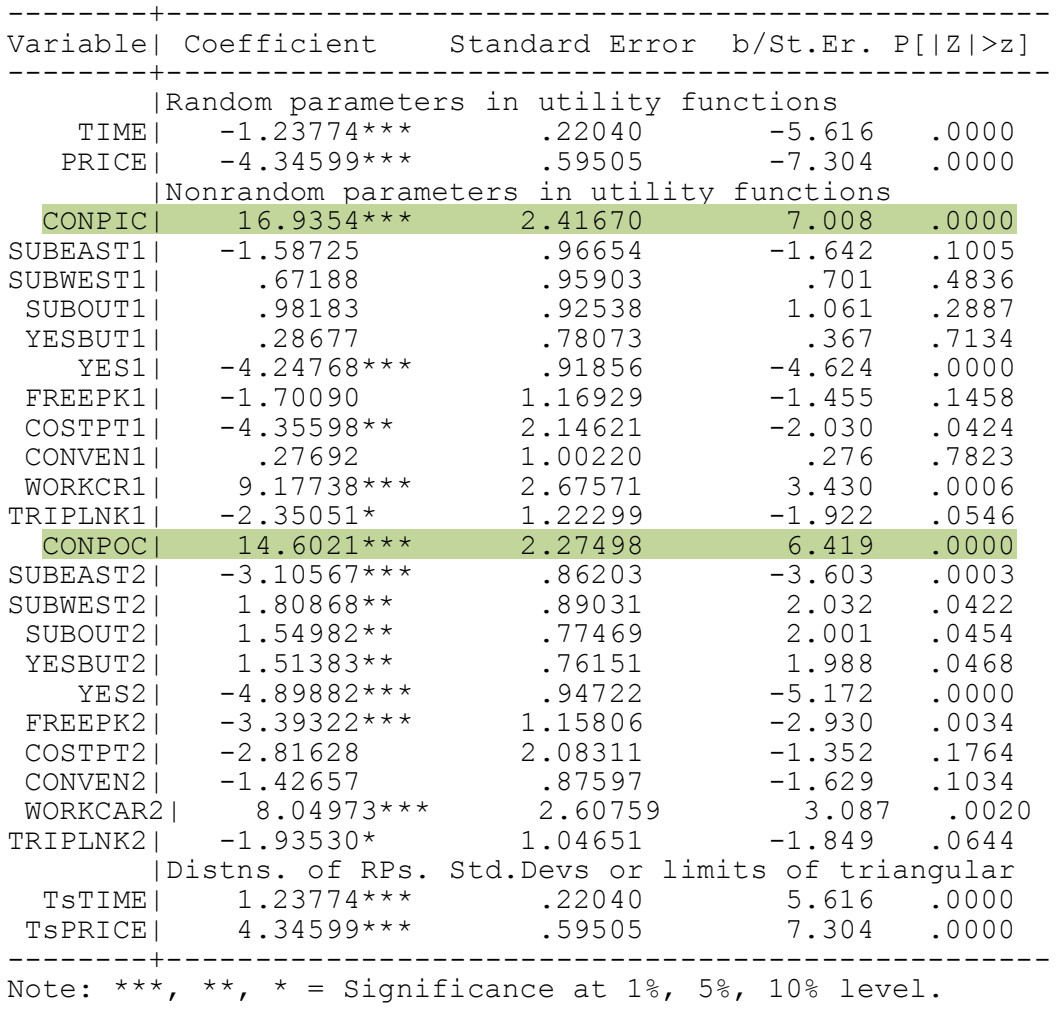

Source: own data

ABBREVIATIONS

CONPIC: Park in the CBD and pay

CONPOC: Park outside the CBD and walk

SUB: Suburb: east, west, out of the region

YESBUT: Yes but public transport inconvenient

YES: Yes public transport is an option

FREEPK: Reason for driving is free parking

COSTPT: Reason for driving is the cost of public transport

CONVEN: Reason for driving is convenience

WORKCR: Reason for driving is work car

TRIPLNK: Reason for driving is trip linking

\section{References}


Adamowicz, W., Dupont, D., Grafton, R. Q., Hill, R. J., Nelson, H., \& Renzetti, S. (2004). The economics of the environment and natural resources. Malden, USA: Blackwell Publishing Ltd.

Akbari, H., Rose, L. S., \& Taha, H. (2003). Analyzing the land cover of an urban environment using high-resolution orthophotos. Landscape and Urban Planning, 63, 1-14.

Albanese, B., \& Matlack, G. (1999). Environmental auditing: Utilization of parking lots in Hattiestburg, Mississippi, USA, and impact on local streams. Environmental Management, 24(2), 265-271.

Anderson, S. P., \& de Palma, A. (2004). The economics of pricing parking. Journal of Urban Economics, 55(1), 1-20.

Auckland Regional Transport and Urban Development Committee (2009). Auckland regional parking strategy. Auckland: Auckland Regional Council.

Banister, D. (2000). Sustainable urban development and transport - a Eurovision for 2020. Transport Reviews 20(1), 113-130.

Barrett, P. (2006). Will unchecked global warming destroy civilisation by century's end? What three degrees of warming really means. Policy Quarterly, 2(1), 5-10.

Beatley, T., Boyer, H., \& Newman, P. (2009). Resilient cities: Responding to peak oil and climate change. London: Island Press.

Beauvais, J. M. (2008). Setting up superstores and climate change. Tours: Beauvais Consultants.

Bennett, J., \& Rolfe, J. (Eds.). (2006). Choice modelling and the transfer of environmental values. Cheltenham, UK: Edward Elgar.

Booz Allen Hamilton (2005). Surface transport costs and charges: Main report Retrieved October 15, 2009, from http://www.beehive.govt.nz/Documents/Files/STCCS\%20Main\%20Report.pdf

Booz Allen Hamilton (2006). International approaches to tackling congestion: Paper (2) final: Parking restraint measures: Victorian Competition and Efficiency Commission.

Brownstone, D., \& Golob, T. F. (2008). The impact of residential density on vehicle useage and energy consumption. Unpublished Working paper. Institute of Transportation Studies \& University of California Irvine

Button, K. (2005). Myths and taboos in transport policy. In P. Rietveld \& R. Stough (Eds.), Barriers to sustainable transport: Institutions, regulation and sustainability. Oxon: Spoon Press.

Button, K. (2006). The political economy of parking charges in "first" and "second-best" worlds. Transport Policy, 13, 470-478.

Callan, S. J., \& Thomas, J. M. (2007). Modelling the market process: A review of basics Environmental economics and management: Theory, politics and applications (4 ed., pp. 22-45). Mason OH USA.

Campbell, C. (2006). What is peak oil Retrieved December 3, 2009, from http://www.peakoil.net/about-peak-oil

Carlsson, F., \& Martinsson, P. (2001). Do hypothetical and actual marginal willingness to pay differ in choice experiments? Application to the valuation of the environment. Journal of Environmental Economics and Management, 41(2), 179-192.

Cerreno, A. L. C. (2002). The dynamics of on-street parking in large central cities. New York: NYU Wagner Rudin Center for Transportation policy and management, New York University.

Chapman, D. G. (2008). Deconstructing development density: Quality, quantity and price effects on household non-work travel. Transportation Research Part A, 42, 1008-1030.

Crouse, D. W. (2000). The real cost of the automobile: A report on recent research. Bulletin of Science, Technology \& Society, 20(5), 366-378. 
Dargay, J., Gately, D., \& Sommer, M. (2007). Vehicle ownership and income growth, worldwide: 1960-2030. Leeds: Institute for Transport Studies, University of Leeds.

Delucchi, M. A. (1997). The social cost of motor vehicle use. Annals of the American Academy of Political and Social Science, 553, 130-142.

Donohue, M. (2008). Environmentally harmful subsidies in the transport sector. Paris: Environmental Directorate OECD.

Donovan, S., Genter, J., Petrenas, B., Mumby, N., Hazledine, T., Litman, T., et al. (2008). Managing transport challenges when oil prices rise. Wellington: New Zealand Transport Authority.

Douglass, M., \& McKenzie, D. (2001). Trips and parking related to land use Volume 1 (No. 209). Wellington: Transfund New Zealand.

Dudding, I. G. (1963). Porirua town development project. NZ Valuer, 18, 81-92.

Einhorn, H. (1969). Porirua town centre. NZIA Journal, 20, 121-123.

EPA (2006). Parking spaces / Community spaces: Finding the balance through smart growth solutions. Washington, DC: U.S. Environmental Protection Agency.

Ewing, R., Bartholomew, K., Winkelman, S., Walters, J., \& Chen, D. (2007). Growing cooler: The evidence on urban development and climate change Chicago: Urban Land Institute.

Fan, H. S. L., \& Lam, S. H. (1997). Parking generation of commercial developments in Singapore. Journal of Transportation Engineering, 123(3), 238.

Feitelson, E., \& Rotem, O. (2004). The case for taxing surface parking. Transportation research Part D, 9, 319-333.

Ferguson, E. (2004). Zoning for parking as policy process: A historical review. Transport Reviews, 24(2), 177-194.

G8 Summit (2009). Environment G8: Chair's summary in four moves for July summit, from http://www.g8italia2009.it/G8/Home/News/G8-G8_Layout_locale1199882116809 1199894488620.htm

Gabites Porter Consultants (1996). Parking demand and trip generation (No. 57). Wellington: Transit New Zealand.

Genter, J. A., Schmitt, L., \& Donovan, S. (2009). The missing link: Parking as the integration of transportation and land use Paper presented at the 2nd Annual Urban Design \& Infrastructure Planning summit.

Glaister, S., \& Mallard, G. (2008). Transport economics: Theory, application and policy. Hampshire UK: Palgrave MacMillan.

Gorham, R. (2002). Air pollution from ground transportation: An assessment of causes, strategies and tactics, and proposed actions for the international community Retrieved January 2, 2010, from http://www.un.org/esa/gite/csd/gorham.pdf

Gray, J. (2004). Policies for rational parking development. Canada: Canadian Parking Association.

Greater Wellington Regional Council (2007). Wellington regional land transport strategy 2007-2016, February 18, from http://www.gw.govt.nz/assets/Transport/Regionaltransport/RLTS/RLTS.pdf

Hanley, N., Shogren, J. F., \& White, B. (2007). Renewable natural resources Environmental economics in theory and practice (2 ed.). New York: Palgrave-McMillan.

Hansen, J. (2008). Tipping point: Perspective of a climatologist. In E. Fearn (Ed.), State of the Wild 2008-2009: A Global Portrait of Wildlife, Wildlands and Oceans. Washington DC: Island Press.

Harris, C. (2007). Lost city: Forgotten plans for an alternative Auckland. Paper presented at the 2nd International conference on Sustainability Engineering and Science. from http://www.nzsses.auckland.ac.nz/conference/2007/papers/HARRIS-Lost\%20City.pdf 
Harrison, G. W. (2007). Making choice studies incentive compatible. In B. J. Kanninen (Ed.), Valuing environmental amenities using stated choice studies: A common sense approach to theory and practice. Dordrecht: Springer.

Hensher, D. A., \& King, J. (2001). Parking demand and responsiveness to supply, pricing and location in the Sydney central business district. Transportation Research Part A, 35, 177-196.

Hensher, D. A., Rosie, J. M., \& Greene, W. H. (2005). Applied choice analysis: A primer. Cambridge: Cambridge University Press.

Hess, D. B. (2001). The effects of free parking on commuter mode choice: Evidence form travel diary data. Los Angeles: Ralph \& Goldy Lewis Center for Regional Studies, University of California.

Hirsch, R. (2005). The inevitable peaking of world oil production. The Atlantic Council Bulletin, XVI (3), 1-10.

Hollyoak, K. (2009, September 10). Trip generation studies: The Australian experience. Paper presented at the Trip generation seminar, Auckland, New Zealand.

Hook, M. (2009). IEA warns: Oil supplies are fast running out. Retrieved 16 September, 2009, from http://www.peakoil.net/headline-news/iea-warns-oil-supplies-are-running-out$\underline{\text { fast }}$

Huber, J., \& Zwerina, K. (1996). The Importance of Utility Balance in Efficient Choice Designs. Journal of Marketing Research, 33(3), 10.

Hull, A. (2008). Policy integration: What will it take to achieve more sustainable transport solutions in cities. Transport Policy, 15, 94-103.

Industry Taskforce on Peak Oil and Energy Security (2010). The oil crunch: A wake-up call for the UK economy Retrieved February 24, 2010, from http://peakoiltaskforce.net/wp-content/uploads/2010/02/final-report-ukitpoes_report_the-oil-crunch_feb20101.pdf

Institute of Transportation Engineers (2004). Parking generation (3 ed.). Washington D.C.: Institute of Transportation Engineers.

IPCC (2007). Climate change synthesis report: Summary for policy makers: Intergovernmental Panel on Climate Change.

Ison, S., \& Rye, T. (2006). Editorial: Parking. Transport Policy, 13, 445-446.

Jakob, A., Craig, J. L., \& Fisher, G. (2006). Transport cost analysis: a case study of the total costs of private and public transport in Auckland. Environmental Science \& Policy, 9(1), 55-66.

Kelly, A. J., \& Clinch, P. J. (2006). Influence of varied parking tariffs on parking occupancy levels by trip purpose. Transport Policy, 13, 487-495.

Kelly, T., \& Incite Ltd (2006). Draft Porirua CBD parking policy framework Porirua City Council.

Kenworthy, J. R. (2003). Transport Energy Use and Greenhouse Gases in Urban Passenger Transport Systems: A Study of 84 Global Cities. Paper presented at the Third Conference of the Regional Government Network for Sustainable Development. from http://cst.uwinnipeg.ca/documents/Transport Greenhouse.pdf

Krewitt, W., Simon, S., Graus, W., Teske, S., Zervos, A., \& Schäfer, O. (2007). The $2{ }^{\circ} \mathrm{C}$ scenario--A sustainable world energy perspective. Energy Policy, 35(10), 4969-4980.

Kroes, E. P., \& Sheldon, R. J. (1988). Stated preference methods: An introduction. Journal of Transport Economics and Policy, 22(1), 11-25.

Krupnick, A., \& Adamowicz, W. L. (2007). Supporting questions in stated choice studies. In B. J. Kanninen (Ed.), Valuing environmental amenities using stated choice studies: A common sense approach to theory and practice. Dordrecht: Springer. 
Lane, M. S. (1966). Porirua City in the making: The urban development of the Porirua Basin. Victoria University, Wellington.

Lindblom, C. E. (1979). Still muddling, not yet through. Public Administration Review, November/December, 517-526.

Litman, T. (1997). Policy implications of full social costing. Annals of the American Academy of Political and Social Science, 553, 143-156.

Litman, T. (2006). Parking management best practices. Chicago, 1ll.: American Planning Association.

Litman, T. (2009a). Evaluating transportation land use impacts: Considering the impacts, benefits and costs of different land use development patterns: Victoria Transport Policy Institute.

Litman, T. (2009b). Parking requirement impacts on housing affordability: Victoria Transport Policy Institute

Litman, T. (2009c). Transportation cost and benefit analysis: Techniques, estimates and implications (2 ed.). Victoria, BC: Victoria Transport Policy Institute.

Loudon, W. R., \& Halbakken, F. (2006). Sacramento Central City Parking Master Plan. Sacramento: Department of Transportation City of Sacramento.

Louviere, J. J., Hensher, D. A., \& Swait, J. D. (2000). Stated choice methods: Analysis and application. Cambridge: Cambridge University Press.

Mansfield, C., \& Pattanayak, S. (2007). Getting started. In B. J. Kanninen (Ed.), Valuing environmental amenities using stated choice studies: A common sense approach to theory and practice. Dordrecht: Springer.

Marsden, G. (2006). The evidence base for parking policies--a review. Transport Policy, 13(6), 447-457.

Mathews, K. E., Freeman, M. L., \& Desvousges, W. H. (2007). How and how much: The role of information in stated choice questionnaires. In B. J. Kanninen (Ed.), Valuing environmental amenities using stated choice studies: A common sense approach to theory and practice. Dordrecht: Springer.

McDonald, S. S. (2007). The parking garage: Design and evolution of a modern urban form. Washington D.C.: Urban Land Institute.

Mildner, G. C. S., Strathman, J. G., \& Bianco, M. J. (2006). Travel and parking behaviour in the United States.

Ministry of Transport (2006). The New Zealand light vehicle fleet: Light fleet statistics 2006. from http://www.transport.govt.nz/about/publications/Documents/NZ-Light-VehicleFleet-7.pdf.

Ministry of Transport (2008). New Zealand household travel survey Retrieved February 19, 2010, from http://www.transport.govt.nz/research/TravelSurvey/

Ministry of Transport (2009). How New Zealanders travel: Trends in New Zealand household travel 1989-2008 Retrieved 20th January, 2010, from http://www.transport.govt.nz/research/Documents/How\%20New\%20Zealanders\%20tr avel\%20web.pdf

Mumford, L. (1961). The city in history: Its origins, its transformations, and its prospects. London: Secker \& Warburg.

Mumford, L. (1964). The highway and the city. London: Secker \& Warburg.

National Research Bureau Ltd (2006). Communitrak Survey: Public perceptions and interpretations of council services and representation Porirua: Porirua City Council.

Nelson City Council (2009). Heart of Nelson strategy. Nelson: Nelson City Council.

New Zealand Government (2008). New Zealand transport strategy 2008 Retrieved February 18, 2010, from http://www.transport.govt.nz/ourwork/Documents/NZTS2008.pdf 
NZ Trips \& Database Bureau Inc (2008). NZTPDB database user guide Febuary 2008. Christchurch: NZTDB Inc.

NZ Trips \& Database Bureau Inc (2009). Parking and Trip generation surveys. Christchurch: NZTDB Inc.

NZPA (2009). Record fall in retail sales figures. Findata. Retrieved from http://www.findata.co.nz/News/2857639/Record_fall_in_retail_sales_figures.htm

Porirua City Council (1998 - 2006). Resource Consent documents.

Porirua City Council (1999). Porirua City District Plan. Porirua: Porirua City Council.

Porter, R. C. (1999). Economics at the wheel: The costs of cars and drivers. San Diego, California: Academic Press.

Poudenx, P. (2008). The effect of transportation policies on energy consumption and greenhouse gas emissions from urban passenger transportation. Transportation Research Part A, 42, 901-909.

Preval, N., Hulme-Moir, A., \& Fougere, G. (2010). Walking the talk: Sustainable transport and local government in four New Zealand cities. In P. Howden-Chapman, R. Chapman \& K. Stuart (Eds.), Sizing up the city: Urban form and transport in New Zealand. Wellington: Steele Roberts.

Property Economics (2008). Porirua City industrial activity review. Porirua: Porirua City Council.

Richardson, H. W., \& Stern, E. (2005). A new research agenda for modelling travel choice and behaviour. In K. Donaghy, S. Poppelreuter \& G. Rudinger (Eds.), Social dimensions of sustainable transport: Transatlantic perspectives. Hants, England: Athenaeum Press Ltd.

Riggs, T. (2009). Sink or swim -- Infrastructure 2009. Press release. Retrieved from http://www.uli.org/News/MediaCenter/PressReleases/2009\%20archives/Content/Infra structure\%202009.aspx

Rose, J. M., \& Bliemer, C. J. (2009). Constructing efficient stated choice experimental designs. Transport Reviews 29(5), 587-617.

Ryan, L., \& Turton, H. (2007). Sustainable automobile transport: Shaping climate change policy. Cheltenham: Edward Elgar Publishing Ltd.

Rye, T., Cowan, T., \& Ison, S. (2004). Expansion of a controlled parking zone (CPZ) and its influence on modal split: The case study of Edinburgh, Scotland and its relevance to elsewhere. Paper presented at the 83rd Annual Meeting of the Transportation Research Board.

Rye, T., Hunton, K., Ison, S., \& Kocak, N. (2009). The role of market research and consultation in developing parking policy. Transport Policy, doi:10.1016/j.tranpol.2008.12.005.

Schaller Consulting (2006). Curbing cars: Shopping, parking and pedestrian space in Soho. Retrieved from http://www.transalt.org/files/newsroom/reports/soho_curbing_cars.pdf

Scrimgeour, A. (1995). From village to city centre. Porirua: Porirua Museum.

Seibert, C. (2008). There's no such thing as a free parking space. Policy 24(2), 7-13.

Shoup, D. (2005). The high cost of free parking. Chicago, Illinois: Planners Press.

Sinclair Knight Merz (2007). kapiti Coast parking study. Paraparaumu: Kapiti Coast District Council.

Sorrell, S., Speirs, J., Bentley, R., Brandt, A., \& Miller, R. (2009). Global oil depletion: An assessment of the evidence for a near-term peak in global oil production. from http://www.ukerc.ac.uk/support/tiki-index.php?page=Global+Oil+Depletion.

Statistics New Zealand (2008). Porirua City quarterly review. Porirua: Statistics New Zealand. 
Stern, N. (2006). Stern review: Executive summary Retrieved 2 April, 2008, from http://www.hmtreasury.gov.uk/media/9/9/CLOSED_SHORT_executive_summary.pdf

Still, B., \& Simmonds, D. (2000). Parking restraint policy and urban vitality. Transport reviews, 20(3), 291-316.

Stubbs, M. (2002). Car parking and residential development: Sustainability, design and planning policy, and public perceptions of parking provision. Journal of Urban Design, 7(2), 213-237.

Sztabinski, F. (2009). Bike lanes, on-street parking and business: A study of Bloor St in Toronto's annex neighbourhood. Retrieved from http://www.cleanairpartnership.org/pdf/Bike\%20Lanes,\%20Parking\%20and\%20Busin ess\%20-\%20Report\%20-\%20Final.pdf

Topp, C. A. (2009). Arapahoe county parking utilization study: Concerning residential transit orientated development. Unpublished Masters, University of Colorado Denver.

Traffic Design Group (2005). Nelson CBD study and traffic model. District plan car parking review report. Nelson: Nelson City Council.

TRCP (2005). Traveler response to transportation system changes: Parking prices and fees: Transit Cooperative Research Program.

UNFCCC (2002). A guide to the climate change convention and its Kyoto Protocol. from http://clima.casaccia.enea.it/ipcc/focalpoint/infoclima/2002/GuideUNFCCKP.pdf.

Vanderbilt, T. (2008). Traffic why we drive the way we do (and what it says about us). New York: Alfred A. Knopf.

Vickrey, W. S. (1963). Pricing and resource allocation in transportation and public utilities: Pricing in urban and suburban transport. The American Economic Review, 53(2), 452465.

Vuchic, V. R. (2000). Transportation for liveable cities. New Jersey: The Centre for Urban Policy Research.

Willson, R. W. (1995). Suburban parking requirements: A tacit policy for automobile use and sprawl. Journal of the American Planning Association, 61(1), 29.

Woodward, A., \& Lindsay, G. (2010). Changing modes of travel in New Zealand cities. In P. Howden-Chapman, R. Chapman \& K. Stuart (Eds.), Sizing up the city: Urban form and transport in New Zealand. Wellington: Steele Roberts.

Worley, H. (2006). Road traffic accidents increase dramatically worldwide. Washington DC: Population Reference Bureau.

Zacharias, J. (2001). Pedestrian behaviour and perception in urban walking environments. Journal of Planning Literature, 16(3), 1-18. 